UNIVERSIDADE DE SÃO PAULO

FACULDADE DE FILOSOFIA, LETRAS E CIÊNCIAS HUMANAS DEPARTAMENTO DE LETRAS ORIENTAIS

PROGRAMA DE PÓS-GRADUAÇÃO EM LÍNGUA HEBRAICA,

LITERATURA E CULTURA JUDAICAS

\title{
O Reino de Judá na época de Ezequias a luz das descobertas epigráficas
}

Carmia Kotler

Carmia.kotler@gmail.com

Dissertação apresentada ao programa de pós-graduação em Língua Hebraica, Literatura e Cultura Judaicas, do Departamento de Letras Orientais da Faculdade de Filosofia, Letras e Ciências Humanas da Universidade de São Paulo.

Orientadora: Profa. Dra. Ruth Leftel

São Paulo 2008 


\section{UNIVERSIDADE DE SÃO PAULO}

FACULDADE DE FILOSOFIA, LETRAS E CIÊNCIAS HUMANAS DEPARTAMENTO DE LETRAS ORIENTAIS PROGRAMA DE PÓS-GRADUAÇÃO EM LÍNGUA HEBRAICA,

LITERATURA E CULTURA JUDAICAS

\section{CARMIA KOTLER}

\section{O Reino de Judá na época de Ezequias a luz das descobertas epigráficas}

Orientadora: Prof ${ }^{\mathrm{a}}$. Dra. Ruth Leftel

São Paulo 2008 
Ao meu querido esposo Mota, Pela compreensão, carinho e incansável apoio durante a elaboração deste trabalho. 
Agradecimentos

À minha orientadora Dra. Ruth Leftel, que, além de apoio acadêmico, confiou em minha capacidade e criatividade ao longo destes anos de mestrado.

Aos professores Dra. Suzana Chwarts e Dr. Reginaldo G. de Araújo, que souberam, com competência, apontar o caminho crítico na direção necessária para o bom aproveitamento deste trabalho.

Ao Rabino Dr. Samy Pinto, que incentivou o olhar crítico da minha pesquisa.

Um agradecimento especial, ao meu pai, Yak Pinsker z’l, que me incentivou a iniciar os estudos de pós-graduação e cuja vasta biblioteca foi a grande motivação para a escolha do tema da minha dissertação.

À minha mãe e minhas irmãs, pelas constantes palavras de apoio e pelo incentivo.

Aos meus filhos Liron e Tomer, pela paciência e incentivo na conclusão deste trabalho. 


\section{Sumário:}

$\begin{array}{ll}\text { Resumo } & 7\end{array}$

$\begin{array}{ll}\text { Abstract } & 8\end{array}$

$\begin{array}{ll}\text { Introdução } & 9\end{array}$

Capítulo 1: Época e Fontes $\quad 12$

1.1 A Idade do Ferro e suas divisões 12

$\begin{array}{ll}1.2 & \text { Arqueologia e Bíblia } \\ \end{array}$

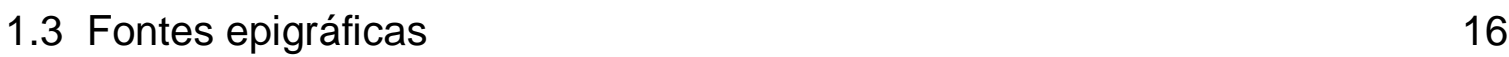

1.3.1 A Estela de Tel Dan 19

$\begin{array}{ll}\text { 1.3.2 Papiros } & 22\end{array}$

1.3.3 Selos e bullae 23

1.3.4 Inscrições de caráter religioso 25

1.4 Historiografia nos livros de Reis e Crônicas 28

$\begin{array}{ll}1.4 .1 \text { Reis } & 30\end{array}$

$\begin{array}{ll}\text { 1.4.2 Crônicas } & 36\end{array}$

1.5 Os anais assírios 43

Capítulo 2: Povos vizinhos do reinado de Ezequias 45

$\begin{array}{lll}2.1 & \text { Filistéia } & 45\end{array}$

2.1.1 Revoltas internas nas cidades filistéias 47

$\begin{array}{lll}2.2 & \text { Assíria } & 48\end{array}$

2.2.1 As invasões assírias na Filistéia entre 734-720 a.e.c. 51

Capítulo 3: O reinado de Ezequias 53

3.1 Os anos de reinado 53

3.2 Suas riquezas $\quad 55$

Capítulo 4: As guerras de Ezequias 58 
4.1 Ezequias e os filisteus 58

$\begin{array}{ll}\text { 4.2 A revolta contra a Assíria } & 60\end{array}$

4.2.1 A situação anterior à revolta 60

4.2.2 Os preparativos de Ezequias: 62

4.2.2.1 Reorganização da administração de Judá 63

4.2.2.2 Organização do exército e pactos com povos vizinhos 66

4.2.2.3 $\mathrm{O}$ fortalecimento de Jerusalém e de outras cidades no reino 68

4.2.2.4 O projeto de abastecimento de água para Jerusalém 70

Capítulo 5: A Jornada de Senaquerib 73

5.1 O relato da Jornada 73

$\begin{array}{ll}\text { 5.2 As fontes sobre a Jornada } & 77\end{array}$

$\begin{array}{ll}\text { 5.2.1 O relato Bíblico } & 79\end{array}$

$\begin{array}{ll}\text { 5.2.1.1 Reis } & 80\end{array}$

5.2.1.2 Crônicas

5.2.1.3 Os profetas Isaías e Miquéias $\quad 84$

5.2.2 Os anais de Senaquerib 86

$\begin{array}{ll}\text { 5.2.3 Os relevos de Laquish } & 91\end{array}$

5.3 As conseqüências da Jornada 94

Considerações finais 95

$\begin{array}{ll}\text { Bibliografia } & 98\end{array}$

$\begin{array}{lr}\text { Anexos } & 108\end{array}$ 
Resumo

O presente trabalho expõe o período em que Ezequias exerceu a regência do reino de Judá no final do século 8 a.e.c. até o início do século 7 a.e.c. Para tanto, foram abordados os seguintes temas: a definição da sua época, a explanação das fontes descobertas até a data de elaboração desta dissertação e, ainda, os trechos relevantes da Bíblia. Para subsidiar o estudo sobre a época do rei Ezequias, procurou-se demonstrar suas ações dentro de um cenário político-militar da região do Antigo Oriente. Para isso, foram pesquisadas as atuações de reis vizinhos, incluindo os registros epigráficos por eles deixados. Procurou-se, ainda, apresentar as controvérsias entre a pesquisa bíblica e a arqueológica-epigráfica da época, através de publicações de historiadores estudiosos da Bíblia e arqueólogos, que às vezes concordam e outras divergem a respeito da análise das descobertas. A atual contestação mundial quanto à veracidade da narrativa bíblica como relato histórico confiável do povo de Israel na antiguidade, torna essa pesquisa relevante por trazer ao leitor interessado uma parte do presente debate.

Palavras Chave: Ezequias, Bíblia, Jerusalém, Assíria, Senaquerib. 
Abstract

This work reveals the period that Hizkiah ruled over Judea at the end of the $8^{\text {th }}$ and beginning of the $7^{\text {th }}$ century BCE. Therefore, the following sources were approached: the definition of his era, presentation of the discoveries until the day of the elaboration of this essay, as well as passages from the Bible. To substantiate this study about the era of King Hizkiah, we have approached his actions within the political-military scenery in the Ancient Orient. To achieve that, the actions of neighboring rulers as well as epigraphic documents, which were left behind, has been analyzed. The controversy between biblical research and archaeologicalepigraphic finds of this period, where confronted, with the aid of the Bible historians' publications as well as archaeologists' publications, which sometimes agree and other times differ, regarding the analysis of the discoveries. Within the present world discussion about the veracity of the Bible as a trusty historical source on the life of the people of Israel in ancient times, this research becomes relevant as it brings the interested reader to be aware of this current debate.

Palavras Chave: Hezekiah, Bible, Jerusalem, Assyria, Sennacherib. 


\section{Introdução}

Quando todo o Israel viu que o rei não os ouvia, responderam-Ihe: "Que parte temos com Davi? Não temos herança com o filho de Jessé. Às tuas tendas, ó Israel." (1Rs 12:16. $)^{1}$

Esse apelo das tribos do norte para a revolta levou à cisão do Reino Unido. Foi um giro decisivo na história de Israel e de Jerusalém. Setenta e cinco anos de reinado de Davi e Salomão chegaram ao fim. No lugar de um Reino Unido restaram dois reinos enfraquecidos: Judá, ao sul, e Israel, ao centro e ao norte.

Desde a cisão até a destruição do Reino de Israel, em 720 a.e.c. aproximadamente, Jerusalém foi a capital de um reino quase insignificante, composto pelas tribos de Judá, Benjamin e uma parte da tribo de Simeon, deixando de ser o centro da vida religiosa, política e econômica de todo o povo de Israel.

Com isso, a posição central de Jerusalém ficou abalada e a sobrevivência dos sacerdotes - que dependia das oferendas levadas ao Templo - passou por dificuldades, afetando, ainda, as finanças do Templo.

Apesar da relativa fraqueza de Judá no início, seus reis nunca aceitaram a existência independente do Reino de Israel e de seus centros separados de adoração. Por isso, empreenderam várias batalhas contra o reino de Israel, na tentativa de unificar os dois reinos, sob a liderança da Casa de Davi em Jerusalém.

Os princípios ideológicos a respeito da importância de Jerusalém e do Templo, que foram estabelecidos por Davi e Salomão, jamais foram extintos. Ao contrário, continuaram a se fortalecer no decorrer das gerações, através das ações dos

\footnotetext{
1 Bíblia de Jerusalém, português, 4ª impressão, Paulus, São Paulo, 2006, p. 488.
} 
sacerdotes, dos profetas, dos poetas, dos escribas do Templo e da dinastia davídica.

Seus descendentes tiveram que lutar contra influências religiosas exógenas, tendo, por isso, que formular reformas religiosas com a meta de purificar a adoração, tais como:

- Rei Asa - séculos 10 e 9 a.e.c.: removeu os ídolos de Jerusalém, depôs sua avó - Maaca - e destruiu seu ídolo - Aserá - que foi queimado no vale de Cedron. $^{2}$

- Rei Joás e o sacerdote Joiada, séculos 9 e 8 a.e.c.: destruíram o templo que Atalia ergueu para Baal. O sacerdote refez a aliança entre Deus, o rei e o povo e restituiu ao trono um rei da Casa de Davi. ${ }^{3}$

- Rei Ezequias, séculos 8 e 7 a.e.c.: aniquilou todos os costumes antigos de culto que eram considerados tradicionais em Judá e, assim, proibiu e destruiu todos os altares no reino e determinou o Templo de Jerusalém como o único lugar para realizar o serviço sagrado a Deus. ${ }^{4} \mathrm{~A}$ vasta reforma realizada por Ezequias iniciou uma nova era na história de Jerusalém, que continuou até a destruição do Templo e da cidade.

- Rei Josias e o sacerdote Helcias, século 7 a.e.c.: realizaram ampla reforma no Templo, na qual foi descoberto o livro da Lei, ${ }^{5}$ que foi usado para fortalecer a crença em Deus dentro do Reino; purificaram o Templo de objetos idólatras e destruíram centros de adoração em Judá. ${ }^{6}$

\footnotetext{
1Rs 15:11-14.

2Rs 11:4-20.

2Rs 18:3-7.

Vide nota 64.

6 2Rs 22:3-20, 23:1-28.
} 
Neste trabalho, tentaremos apresentar as ações do rei Ezequias segundo as teorias mais recentes (além de algumas antigas), parte de suas reformas e suas importantes atividades políticas - envolvendo os povos vizinhos e o maior império da época, o assírio.

Para tanto, abordaremos a época em que viveu, bem como as fontes utilizadas pelos estudiosos que pesquisaram as informações a respeito das questões que a ele se referem. Essas fontes englobam a Bíblia e as descobertas arqueológicas e epigráficas do Oriente Antigo.

Usaremos a Bíblia como fonte primeira, além das recentes pesquisas publicadas em hebraico a respeito das diferenças entre os livros históricos de Reis e Crônicas, que abordam o mesmo período histórico de maneiras diferentes.

Este trabalho demonstra que os pesquisadores analisam a situação de Judá dentro do contexto histórico-político dos povos do Oriente Antigo da época. 


\section{Capítulo 1: Época e fontes}

1.1. A ldade do Ferro e suas divisões

A expressão "Idade do Ferro", relativa à região que estudamos, foi atribuída ao período entre o final da Idade do Bronze Recente, por volta de 1200 a.e.c., até a destruição do primeiro Templo de Jerusalém, em 586 a.e.c. Nela podemos apreender uma relação entre os achados arqueológicos, as pesquisas bíblicas e o estudo da história do período bíblico. Esse período é paralelo à maior parte da época coberta pelos relatos bíblicos.

A pesquisa da Idade do Ferro em Israel concentra-se na relação entre os achados arqueológicos e as fontes históricas, tanto das que se encontram na Bíblia, quanto das extra-bíblicas.

No decorrer das pesquisas realizadas em Israel, foram propostas subdivisões da Idade do Ferro de vários modos. Até o início dos anos sessenta, a divisão mais aceita pelos pesquisadores foi:

Idade do Ferro A - 1200-920 a.e.c.

Idade do Ferro B - 920-586 a.e.c. $^{7}$

De acordo com essa divisão, na primeira fase da Idade do Ferro estão incluídas a época bíblica dos juízes e o Reino Unido até o seu final. A segunda fase

\footnotetext{
${ }^{7}$ Mazar, Amihai. The Archaeology of Ancient Israel in the Biblical Period - The Iron Age I (em hebraico), Open University, Tel Aviv, 1990, p. 11. É importante ressaltar que Albright fez a seguinte divisão: Idade do Ferro I: séculos 12-10 a.e.c., Idade do Ferro II: século 9 e início do 6 a.e.c., Idade do Ferro III: de 550-330 a.e.c. In: Albright, William Foxwell. The Archaeology of Palestine (em hebraico), Daat, Tel Aviv, 1951, pp. 103-130.
} 
estende-se da cisão dos reinados de Judá e Israel até a destruição do primeiro Templo de Jerusalém.

Como resultado das escavações em Hasor, ${ }^{8}$ comandadas por Yohanan Aharoni e Ruth Amiran, em 1958, surgiu uma nova proposta de divisão da Idade do Ferro:

Idade do Ferro A - 1200-1000 a.e.c.

Idade do Ferro B - 1000-586 a.e.c.

Segundo essa divisão, o primeiro período é paralelo à época do assentamento do povo de Israel em Canaã até a morte de seu primeiro rei, Saul, e o segundo período estende-se da monarquia de Davi até a destruição do primeiro Templo.

Conseqüentemente, Amihai Mazar ${ }^{9}$ sugere a seguinte divisão:

Idade do Ferro A1 - 1200-1150 a.e.c.

Idade do Ferro A2 - 1150-1000 a.e.c.

Idade do Ferro B1 - 1000-925 a.e.c.

Idade do Ferro B2 - 925-720 a.e.c.

Idade do Ferro B3 - 720-586 a.e.c.

Essa divisão enfatiza os eventos históricos, tais como a divisão da monarquia e a conquista assíria do Reino do Norte.

\footnotetext{
8 Aharoni, Yohanan. The Land of Israel in Biblical Times a Historical Geography (em hebraico), The Bialik Institute, Jerusalém, 1962, pp. 110-111.

9 Mazar, Amihai. Arqueologia na terra da Bíblia - 10.000 - 586 a.C., Paulinas, São Paulo, 2003, pp. $290-291$.
} 


\subsection{Arqueologia e Bíblia}

Até a Idade do Ferro B1, cujos achados arqueológicos determinaram os acontecimentos históricos, a Bíblia é utilizada como pano de fundo. A partir da Idade do Ferro B1 - que é a época do Reino Unido de Israel - podemos encontrar na Bíblia relato historiográfico. ${ }^{10}$ Além dos livros da Bíblia considerados históricos, tais como 1 e 2 Samuel, 1 e 2 Reis e 1 e 2 Crônicas, nos livros dos profetas há muitos detalhes que completam a imagem da vida cotidiana, da lei, das crenças, das idéias e do culto em Israel e Judá. ${ }^{11}$

A arqueologia da Idade do Ferro em Israel é tida como arqueologia histórica, isto é, o arqueólogo estuda as fontes escritas, principalmente a Bíblia, e tenta completar a imagem histórica de acordo com os achados arqueológicos. Há uma forte relação entre a pesquisa histórica e a pesquisa arqueológica. ${ }^{12}$ Vale lembrar que o resultado mais importante da pesquisa arqueológica é a concretização da vida na antiguidade e não a confirmação do relato bíblico. A arqueologia oferece o fundamento que completa o relato do historiador. ${ }^{13}$

Durante as escavações em Israel e no Oriente Próximo, muitos pesquisadores tentaram relacionar, de maneira forçada, os achados arqueológicos às narrações da

\footnotetext{
${ }^{10}$ Maguidov, Rony define o termo: "Historiografia é uma escrita histórica movida por tendências e opiniões do historiador que as descreve, há historiadores movidos por sua visão do mundo." In: "Historiografia" (em hebraico), Mikranet, 2005. Disponível em:<http://lib.cet.ac.il/pages/item.asp?item =13168\& kwd=4024> (acesso em 22/05/2008); Zeligman, Itzhak Arie assim descreve o termo: "A historiografia bíblica é uma redação completa e contínua baseada em acontecimentos e tradições anteriores."

In: מודות אטיולוגיים בהיסטוריוגרפיה המקראית המראת (As Bases Etiológicas na Historiografia Bíblica.)

In: מחקרים בתולדות ישראל בתקופת המקרא (Pesquisas da História de Israel na Época Bíblica), Ed.: Horovitz Avi, Tov Emanuel e Japhet Sara; IL Magnes, Jerusalém, 1992, p. 141.

${ }^{11}$ Barkai, Gabriel. The Archaeology of Ancient Israel in the Biblical Period - The Iron Age II (em hebraico), Open University, Tel Aviv, 1990, pp. 83-88.

12 Idem.

${ }^{13}$ Grober, Meir. ישראל בימי קדם מנקודת מבט פוסט-קולוניאלית' (Israel na Antiguidade do ponto de vista Pós-Colonial), Resling 7, verão de 2000, Tel Aviv, pp. 113-118.
} 
Bíblia. ${ }^{14}$ Entretanto, a equivalência entre as evidências epigráficas encontradas e a vida dos reis - cujos nomes aparecem na Bíblia - não é obrigatória. Mas, alguns dos acontecimentos mencionados na Bíblia - como a construção de uma cidade, ou sua destruição em guerras ou terremotos e conquistas militares - podem auxiliar na datação dos achados arqueológicos. Assim, analisando cuidadosamente as descobertas arqueológicas, podemos dizer que esses dados e a Bíblia se complementam. ${ }^{15}$

${ }^{14}$ Herzog Ze'ev, The Scientific Revolution in the Archaeology of Ancient Israel (em hebraico). In: The Controversy over the Historicity of the Bible. Ed.: Lee Israel Levin e Mazar Amihai, Yad Ben Zvi e Dinur Center, Jerusalém, 2001, pp. 52-65; Ben-Tor, Amnon. מהי ארכיאולוגיה? פרקי מבוא (O que é Arqueologia? Capítulos de Introdução). In: מבוא לארכיאולוגיה של ארץ ישראל בתקופת המקרא (Introdução à Arqueologia de Israel na Época Bíblica), Ed.: Ben-Tor Amnon, Open University Tel Aviv, 1989, pp. 42-42.

${ }^{15}$ Vide nota 11. 


\subsection{Fontes epigráficas}

A principal fonte para o estudo da época da monarquia em Israel são os livros historiográficos da Bíblia. A eles devemos acrescentar fontes extra-bíblicas egípcias, assírias e babilônias - a maioria em obeliscos ou relevos gravados nas paredes dos templos e das fortalezas - além de inscrições descobertas em Israel e suas redondezas.

Os registros em hebraico referentes ao período da monarquia, já conhecidos, incluem: textos oficiais em monumentos; óstraca; estelas; pequenas anotações em vasos de cerâmica; devoções; selos, bullae (impressões de selos); orações; textos literários gravados em paredes; jarros e talismãs de metal.

Devemos lembrar que todas essas descobertas representam somente uma pequena porção de tudo o que foi escrito em Israel no período da monarquia, já que os principais materiais epigráficos usados na Idade do Ferro foram papiros e pergaminhos, materiais de curta durabilidade. Apesar de fechados com cordas e bullae, a única parte preservada desses documentos oficiais é a peça de argila estampada - bullae. Esse artefato foi encontrado em abundância.

O conteúdo dos óstraca é principalmente burocrático, e entre os mesmos há recibos, comprovantes de entrega, listas de mercadorias, listas de nomes, rascunhos de cartas etc. Foram descobertas grandes quantidades de óstraca em Samaria, Laquis e Arad, como também em muitos outros sítios arqueológicos espalhados em Israel. A maioria dos óstraca encontrados é datada do século 7 e início do 6 a.e.c. Os da Samaria são datados do final do século 8 a.e.c., antes da 
conquista da Samaria em 720 a.e.c., aproximadamente. Alguns dos óstraca achados em Arad são datados dos séculos 9 e 8 a.e.c. ${ }^{16}$

Registros de caráter religioso, escritos sobre utensílios de cerâmica e pedra, como também em paredes, auxiliam na ligação de personagens bíblicos aos achados arqueológicos. ${ }^{17}$

Além das inscrições em hebraico, foram encontradas pequenas partes de inscrições assírias - que parecem ser pedaços de estelas da monarquia Assíria em Ashdod, Samaria, Bet Shemesh e Gezer. Um pedaço de estela com inscrição em hieróglifo, com o nome do Faraó Sisaque, foi achado numa muralha do século 9 a.e.c., em Meguido. ${ }^{18}$

Vários documentos epigráficos localizados em Israel complementam, em determinados detalhes, a descrição bíblica. Apresentam particularidades sobre nomes próprios, funções burocráticas, administração de reinado e sua economia, costumes e culto no Reino de Israel, no Reino de Judá e nos reinos vizinhos, durante os séculos 8 a 6 a.e.c.

$\mathrm{Na}$ Bíblia, são mencionados poucos documentos escritos em pedras, em paredes, ou outros materiais: as tábuas da lei, ${ }^{19}$ os nomes das tribos de Israel sobre ônix no efod - a vestimenta sacerdotal, ${ }^{20}$ as frases escritas nos umbrais das portas, ${ }^{21}$

${ }^{16}$ Sass, Benjamin. Script and Inscriptions in the Biblical Period (em hebraico), Open University, Tel Aviv, 1992, pp. $10-11$.

${ }^{17}$ Barkai, Gabriel. The Archaeology of Ancient Israel in the Biblical Period - The Iron Age II (em hebraico), Open University, Tel Aviv, 1990, p. 85.

${ }^{18}$ Idem.

${ }^{19}$ Ex 32:15: "Moisés voltou-se e desceu da montanha com as duas tábuas do Testemunho nas mãos, tábuas escritas nos dois lados: estavam escritas em uma e outra superfície." Bíblia de Jerusalém, 2003, p. 149.

${ }^{20}$ Ex 28:9-12: "Tomarás duas pedras de ônix e gravarás nelas os nomes dos israelitas. Seis nomes em uma e os outros seis na outra, por ordem de nascimento... Porás as duas pedras nas ombreiras do efod, como memorial para os israelitas." Bíblia de Jerusalém, 2003, p. 142.

${ }^{21}$ Dt 6:6-9: "Que estas palavras que hoje te ordeno estejam em teu coração... tu as escreverás nos umbrais da tua casa, e nas tuas portas." Bíblia de Jerusalém, 2003, p. 266. 
no Tsits (diadema) de ouro, ${ }^{22}$ as pedras sobre as quais foi escrita a Torá, quando o povo de Israel atravessou o rio Jordão, ${ }^{23}$ os documentos escritos apresentados ao povo pelos profetas $^{24}$ etc.

Vale ressaltar que, na Bíblia, o termo "livro" refere-se ao objeto livro ${ }^{25}$ como o conhecemos nos dias de hoje, mas também representa quase todos os tipos de documentos, como cartas ${ }^{26}$ e documentos judiciais. ${ }^{27}$

${ }^{22}$ Ex 28:36: "Farás uma flor de ouro puro, na qual gravarás, como se gravam os selos..." Bíblia de Jerusalém, 2003 , p. 143.

${ }^{23}$ Dt 27:2-3: "No dia em que atravessardes o Jordão para entrardes na terra..., erigirás grandes pedras e as caiarás. E sobre elas escreverás todas as palavras desta Lei...” Bíblia de Jerusalém, 2003, p. 290.

${ }^{24}$ Por exemplo: Is 8:1: “... me disse: Toma uma tabuinha de bom tamanho e nela escreve com estilete comum...” Bíblia de Jerusalém, 2003, p. 1266.

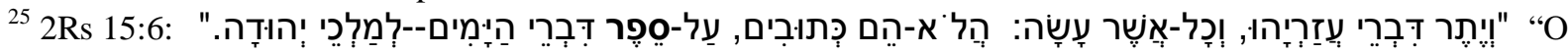
resto da história de Ozias e tudo o que fez não está escrito no livro dos Anais dos reis de Judá?" Bíblia de Jerusalém, 2003, p. 527.

${ }^{26}$ 2Rs 5:5: " E o rei de Aram respondeu: "vai que eu enviarei uma carta ao rei de Israel'." Bíblia de Jerusalém, 2003, p. 512.

${ }^{27}$ Jr 32:11: " "Depois eu tomei o contrato de compra, o exemplar selado...” Bíblia de Jerusalém, 2003, p. 1422. 


\subsubsection{A Estela de Tel Dan}

Para exemplificar o que foi dito acima, podemos examinar as três partes de estela descobertas na pavimentação de entrada na cidade de Tel Dan, no norte de Israel, por Guila Kuk, Avraham Biran e Joseph Naveh.

O fragmento maior mede $32 \times 22 \mathrm{~cm}$ e contém 13 linhas de uma escrita alfabética aramaica, com palavras separadas por ponto e frases por traço, e foi encontrado em 1993. Os outros dois fragmentos da Estela, encontrados em 1994, contêm 8 linhas cada e, apesar de não se encaixarem perfeitamente ao primeiro, apresentam uma continuidade de conteúdo. ${ }^{28}$

A Estela descreve as vitórias do rei de Aram, Hazael, sobre o rei de Israel, Jorão, filho de Acab, e sobre o rei de Judá, Ocozias, filho de Jorão, da casa de Davi. ${ }^{29}$ Ocozias é apresentado como o rei da casa de Davi, בית דוד, o que pode confirmar a existência de uma dinastia real que se iniciou com o rei Davi. ${ }^{30}$

O relato que aparece na Estela combina com o texto em 2Rs 8:25-29: “Ocozias... tornou-se rei de Judá... Foi com Jorão, filho de Acab, combater Hazael, rei de Aram, em Ramot de Galaad. Mas os arameus feriram Jorão. O rei Jorão voltou a Jezrael para tratar-se dos ferimentos recebidos dos arameus em Ramot, quando combatia contra

\footnotetext{
${ }^{28}$ Vide anexo 1.

${ }^{29}$ [קתלת.אית.יהו]רם.בר[אחאב.] מלך.ישראל.וקתל[ת.אית.אחז]יהו.בר]יהורם.מל] ך.ביתדוד.ואשם.[אית.קרית.הם.חרבת.ואהפך.א. (Vide tradução no anexo 1.)

${ }^{30}$ Biran, Avraham e Naveh, Joseph. An Aramaic Stele Fragment from Tel Dan, Israel Exploration Journal 43, 1993, pp. 81-98. Biran, Avraham e Naveh, Joseph. The Tel Dan Inscription: A New Fragment, Israel Exploration Journal 45, 1995, pp. 1-18; Neeman, Nadav. הכתובת הארמית מתל דן בהארה היסטורית (A Inscrição Aramaica de Tel Dan à luz da História), Eretz Israel Archaeological, Historical and Geographical Studies, vol. 26, Israel Exploration Society, Jerusalém, 1999, pp. 112-118; Rendsburg, Gary A. On the writing ביתדוד. in the Aramaic Inscription from Tel Dan, Israel Exploration Journal 45, 1995, pp. 19-21; Takamitsu, Muraoka. Linguistic Notes on the Aramaic Inscription from Tel Dan, Israel Exploration Journal 45, 1995, pp. 22-25; Schniedewind, William M. Tel Dan Stele: New light on Aramaic and Jehu's Revolt, Bulletin of the American Schools of Oriental Research 302, maio 1996, pp. 75-90.
} 
Hazael, rei de Aram; e Ocozias, filho de Jorão, rei de Judá, desceu a Jezrael para visitar Jorão, filho de Acab, que estava enfermo." 31

A única diferença entre os dois textos está no relato do final das batalhas. Em 2Rs consta que Jeú, filho de Josafá, matou os dois reis, ${ }^{32}$ e, na Estela, o rei de Aram vangloria-se por ter matado os dois reis.

Essa Estela, datada dos séculos 9-8 a.e.c., é a mais antiga evidência em escrita alfabética encontrada em Israel.

A reconstituição dos trechos fragmentados foi feita com o auxílio dos relatos bíblicos e de outro achado arqueológico: a Estela de Mesha. ${ }^{33}$

Essa última foi descoberta em 1868, em Diban, na Jordânia. A Estela foi gravada em basalto, em meados do século 9 a.e.c, numa escrita alfabética hebraica com alguns traços moabitas, como por exemplo ת como sufixo feminino e נ como sufixo plural masculino. Nela, podem ser lidas 34 linhas de prováveis 36 , com um ponto entre as palavras e um traço separando as frases. ${ }^{34}$ Ela mede $124 \times 71 \mathrm{~cm} \mathrm{e}$ seu topo é arredondado. ${ }^{35}$

A Estela de Mesha descreve as guerras do rei Mesha contra Omri, rei de Israel. O texto está redigido na $1^{\underline{a}}$ pessoa e é dedicado a Kamush, deus de Moab. O relato engrandece o rei Mesha, que libertou Moab da mão opressora de Israel, venceu todos os inimigos, aumentou as suas cidades e realizou várias construções.

\footnotetext{
${ }^{31}$ Bíblia de Jerusalém, 2003, p. 518.

32 2Rs 9:24-27: "Mas Jeú já tinha retesado seu arco e atingiu Jorão entre as espáduas; a flecha atingiu o coração do rei, que tombou dentro do carro... Vendo isso, Ocozias, rei de Judá, fugiu pela estrada de Bet-Gã; mas Jeú o perseguiu e gritou: 'Matai-o também', feriram-no dentro do seu carro, na subida de Gaver, que fica perto de Jeblaam; refugiou-se em Meguido e lá morreu.” Bíblia de Jerusalém, 2003, p. 519.

33 2Rs 3:4-5: "Mesha, rei de Moab, era criador de gado e pagava ao rei de Israel cem mil cordeiros... mas quando morreu Acab, o rei de Moab revoltou-se contra o rei de Israel.” Bíblia de Jerusalém, 2003, p. 509.

34 Vide anexo 2.

${ }^{35}$ Sass, Benjamin. Script and Inscriptions in the Biblical Period (em hebraico), Open University, Tel Aviv, 1992, pp. 30-34.
} 
O estilo da Estela de Mesha é muito parecido com o da Estela de Tel Dan, que descreve a vitória do rei de Aram sobre seus inimigos, entre eles os reinos de Israel e de Judá.

Existe muita semelhança entre os primeiros parágrafos dessas Estelas. Nas duas, os acontecimentos do passado servem como justificativa para os ataques e conquistas dos reis naquele período. Esse tipo de preâmbulo serviria para convencer o destinatário da composição, Deus, e os habitantes do reinado, de que a ação do rei não é um ato brutal gratuito, mas, sim, resposta justificada para as violentas ações anteriores que ocorreram nos dias dos pais daqueles reis.

De acordo com Neeman, ${ }^{36}$ a colocação de estelas com escrita alfabética era um costume assírio, que visava a explanação das conquistas dos reis para amedrontar os habitantes locais.

Ao cotejar os achados arqueológicos com o relato bíblico, podemos ter uma visão mais ampla dos personagens bíblicos e suas ações, bem como uma melhor compreensão dos objetos encontrados nas escavações arqueológicas.

\footnotetext{
${ }^{36}$ Neeman, Nadav. הכתובת דארמית מתל דן בהזרה היסטורית, (A Inscrição Aramaica de Tel Dan à luz da História), Eretz Israel Archaeological, Historical and Geographical Studies, vol. 26, Israel Exploration Society, Jerusalém, 1999, pp.112-118.
} 


\subsubsection{Papiros}

Até hoje,${ }^{37}$ foram encontradas somente duas cartas escritas em papiro. Ambas são datadas do século 7 a.e.c. e têm estilo semelhante ao das Estelas de Mesha e de Tel Dan.

Uma das cartas foi localizada numa caverna em Wadi Muraba'at, no deserto de Judá e mede 9x18cm. Nela está escrito:

"אמר]...]יהו.לך.שלח.שלחת.את.שלם.ביתך.

ועתָ.אל.תשמע.לכ[ל.ד[בר.אשר.ידבר.אליך"

"E disse [...]yahu para ti: como está a sua família? E agora não ouviste tudo que te dirá."38

A outra carta é um veredicto judicial divino e foi descoberta selada com bullae. Nela está escrito:

"כה. אמרו. אלהן. לגרא. לך. המרזח. והרחין. וה

בית. וישעא. רחק. מהם. ומלכא. השלש"

A carta foi traduzida da seguinte forma:

“Assim disse Deus para Guera: Ishá tem que se afastar da festa do velório, do moinho e da casa. Essa lhe pertence. Assim escreveu Malká o escriba." 39

E nos informa sobre a introdução da palavra divina em casos cotidianos que exigiam solução, como aparece em Números 22:8. ${ }^{40}$

\footnotetext{
${ }^{37}$ Ahituv, Shmuel. A Divine Verdict: A Judicial Papyrus of the Seventh Century BCE (em hebraico), Eretz, Israel Archaeological, Historical and Geographical Studies, Frank Cross, vol. 26, Israel Exploration Society, Jerusalém, 1999, pp. 1-4.

38 Sass, Benjamin. Script and Inscriptions in the Biblical Period (em hebraico), Open University, Tel Aviv, 1992, p. 38. O texto foi traduzido pela presente autora, de acordo com as explicações de Benjamin Sass.

${ }^{39}$ Vide nota 37 . O texto foi traduzido pela presente autora, a partir da detalhada análise de Shmuel Ahituv.
} 


\subsubsection{Selos e Bullae}

Foi encontrado um bullae queimado ${ }^{41}$ datado do século 7 a.e.c., que mede $10,5 \times 2,0 \mathrm{~mm}$. Ele retrata uma figura de besouro com duas asas empurrando uma pequena quantidade de lama. Abaixo da figura está escrito: "לחזקיהו•אחזימלך•/יהדה (Ihzqyhw. 'hzmlk/yhdh) (Belonging to Hezekiah, (son of) Ahaz, king of Judah) e acima dela está escrito: "הדה" (Judá). ${ }^{42}$

O besouro com quatro ou duas asas é um motivo originário do Egito e parece ser o símbolo oficial do Reino de Judá nos dias de Ezequias. ${ }^{43}$ A pequena quantidade de lama que está sendo empurrada representa o nascer do sol, símbolo da salvação. ${ }^{44}$

Tanto a escrita como o desenho de besouro assemelham-se muito àqueles encontrados nas alças dos vasos "למלך" Imlk ("pertencente ao rei"), descobertos em abundância nas ruínas queimadas da cidade de Laquish e em outros sítios arqueológicos da região. ${ }^{45}$ As letras são semelhantes à inscrição localizada no túnel de Siloé. Todos são datados do século 7 a.e.c., aproximadamente, e atribuídos ao rei Ezequias.

40 "E ele thes disse: Ficai aqui esta noite e eu vos responderei segundo o que Iahweh me disser." Bíblia de Jerusalém, 2003, p. 236.

${ }^{41}$ Vide anexo 3.

${ }^{42}$ Cross, Frank Moore. A Bulla of Hezekiah, King of Judah. In: Essays in the Archaeology and Biblical Interpretation in Honor of Eduard F. Campbell Jr. Ed.: Prescott H. Williams Jr. e Theodor Hiebert, Realias Dei, Scolars Press, Atlanta, Georgia, 1999, pp. 62-66.

${ }^{43}$ Aharoni, Yohanan. The Land of Israel in Biblical Times a Historical Geography (em hebraico), Bialik Institute, Jerusalém, 1962, pp. 316-323; Mazar, Amihai. Arqueologia na terra da Bíblia - 10.000 - 586 a.C., Paulinas, São Paulo, 2003, pp. 432-494.

${ }^{44}$ Sass, Benjamim. Studies in the Iconography of Northwest Semitic Inscribed Seals, Fribourg University Press, Fribourg, 1993, pp. 214-219; Malaquias 3:20.

${ }^{45}$ Ussishkin, David. קנקני 'למלך' וחפירות לכיש (Os Vasos de 'Lmlk' e as Escavações em Laquish), Kadmoniot 9, Israel Exploration Society, Jerusalém, 1976, pp. 63-68. 
Muitos dos selos encontrados continham nomes dos servos dos reis, como por exemplo:

(Belonging to Yehozarah son (of) Hilqi[ya]hu servant (of) Hizqiyahu); "לשמע עבד ירבעם" (Belonging to Shem'a servant of Jerobo'am) e outros. ${ }^{46}$

O bullae aqui mencionado é o primeiro descoberto com o nome de um rei cuja história é relatada na Bíblia.

${ }^{46}$ Sass, Benjamin. Script and Inscriptions in the Biblical Period (em hebraico), Open University, Tel Aviv, 1992, p. 54; Hestrin Ruth e Dayagi Michal, A Seal Impression of a Servant of King Hezekiah. In: The Israel Exploration Journal Reader, vol. II, Ed.: Orlinsky Harry Meyer, Ktav Publishing House, Jersey City, 1981, p. 1173. 


\subsubsection{Inscrições de caráter religioso}

Em Tell Deir'Alla, no Vale do Jordão, ${ }^{47}$ foi descoberta uma inscrição datada de 840-760 a.e.c., feita com tinta preta e vermelha sobre uma parede recoberta de argamassa, que mede $100 \times 31 \mathrm{~cm}$ e contém 55 linhas. Ela conta uma história sobre Balaão, o adivinho, que teve uma revelação divina, na qual foi avisado sobre um desastre que estaria se aproximando. ${ }^{48} \mathrm{~A}$ história de Balaão aparece também no relato bíblico, em Números 22:24.

Outro tipo de inscrição de caráter religioso aparece nos talismãs de prata pura (99\%), com conteúdo quase idêntico à benção dos sacerdotes, ${ }^{49}$ reconhecida na Bíblia em Números 6:24-27.

O uso de jóias como artefato religioso na antiguidade é mencionado na Bíblia, em Êxodo 13:9 "E será como sinal na tua mão, um memorial entre os teus olhos.") ${ }^{51}$ É possível perceber que os talismãs foram usados como jóias pelo desgaste existente nos cantos de cada um.

Esses talismãs foram descobertos em Katef Hinom, Jerusalém (caverna ํํ25), no ano de 1979, pelo arqueólogo Gabriel Barkai, são datados da segunda metade do século 7 a.e.c. e medem $27 \times 97 \mathrm{~mm}$ e $11 \times 39 \mathrm{~mm}$.

\footnotetext{
${ }^{47}$ Barkai, Gabriel. The Archaeology of Ancient Israel in the Biblical Period - The Iron Age II, Open University, Tel Aviv, 1990, p. 85; Margolis, Baruch. עלילות בלעם בר בעור מעמק סוכות (A Trama de Balaão filho de Beor do Vale de Sucot), Al Haperek 15, outubro 1998, Ministério da Educação, Israel. Disponível em: <http://lib.cet.ac.il/pages/item.asp?item=7595 > (acesso em 03/05/2008); Franken, Hendricus Jacobus. Vetus Testamentum, vol. 17, Fasc. 4, Out. 1967), pp. 480-481.

${ }^{48}$ Neeman, Nadav. על כמה כתובות עבריות קדומות וחשיבותן (Sobre Algumas Inscrições Hebraicas Antigas e sua Importância), Tzion 82, 2007, pp. 225-230; Davies, Graham. Hebrew Inscriptions. In: The Biblical World, vol. I, Ed.: John Barton, Taylor e Francis, Londres, 2002, pp. 270-286.

${ }^{49}$ Vide anexo 4.

${ }^{50}$ Sass, Benjamin. Script and Inscriptions in the Biblical Period (em hebraico), Open University, Tel Aviv, 1992, pp. 6-7; Vainstub, Daniel. Hebrew Inscriptions of the First Temple Period (em hebraico). In: The History of Jerusalem, the Biblical Period. Ed.: Ahituv Shmuel e Mazar Amihai, Yad Ben-Zvi Press, Jerusalém, 2000, pp. 271-305.

${ }^{51}$ Bíblia de Jerusalém, 2006, p. 120.
} 
No maior, existem vestígios de 18 linhas escritas, com 5-7 letras em cada linha, aproximadamente 140 letras no total. No menor, há 15 linhas, com 5 letras cada uma. $^{52}$

No talismã maior está escrito:

"יברכך יהוה וישמרך יאר יהוה פניו אליך ויחנך וישם לך שלום"

(May Yahweh bless you and keep you; may Yahaweh make his face shine upon you and be gracious to you, and give you peace. $)^{53}$

No talismã menor está escrito:

"יברכך יהוה וישמרך יאר יהוה פניו אליך ויחנך"

(May Yahweh bless you and keep you; may Yahaweh make his face shine upon you and be gracious to you. $)^{54}$

Na Bíblia, em Números 6:24-26, está escrito:

"יברכך יהוה וישמרך יאר יהוה פניו אליך ויחנך ישא יהוה פניו אליך וישם לך שלום"

("Iahweh te abençoe e te guarde, lahweh faça resplandecer o seu rosto sobre ti e te seja benigno, lahweh mostre para ti a sua face e te conceda a paz." $)^{55}$

As placas de prata apresentam a versão bíblica mais antiga encontrada até hoje, a única anterior à conclusão do cânon bíblico. Sua importância reside na

\footnotetext{
${ }^{52}$ Barkai, Gabriel. ברכת הכהנים על לוחית כסף מכתף הינום בירושלים (A Benção dos Sacerdotes sobre Placa de Prata de Katef Hinom em Jerusalém), Katedra 52, Jerusalém, 1989, pp. 37-76.

${ }^{53}$ Davies, Graham. Hebrew Inscriptions. In: The Biblical World, vol. I, Ed.: John Barton, Taylor e Francis, Londres, 2002, pp. 284.

${ }^{54}$ Idem.

${ }^{55}$ Bíblia de Jerusalém, 2006, p 212
} 
demonstração de que a benção dos sacerdotes consolidou-se antes da destruição do primeiro Templo. ${ }^{56}$

${ }^{56}$ Sass, Benjamin. Script and Inscriptions in the Biblical Period (em hebraico), Open University, Tel Aviv, 1992, pp. 6-7; Neeman, Nadav. על כמה כתובות עבריות קדומות וחשיבותן (Sobre Algumas Inscrições Hebraicas Antigas e sua Importância), Tzion 82, 2007, pp. 225-230. 


\subsection{Historiografia nos livros de Reis e Crônicas}

A formação da literatura histórica de Israel, como a de outras nações, é resultado de um processo muito longo, baseado nas tradições e na composição social do povo. Os sinais característicos de uma escrita histórica são: a junção de acontecimentos isolados numa trama contínua; a distinção de elementos mitológicos e lendários dos acontecimentos reais; o uso de várias fontes e sua combinação; uma visão histórica global. ${ }^{57}$

A concepção histórico-filosófica da Bíblia traz o monoteísmo como a base de toda sua narrativa. Assim, de acordo com esse entendimento, a história de Israel, desde o princípio, é a concretização da palavra de Deus. Deus é uma vontade moral, que se coloca perante o homem como quem exige e comanda; promete e ameaça; domina o homem e a natureza de forma absoluta. ${ }^{58}$

A destruição de Jerusalém e o exílio da nação foram vistos pelo povo como castigos de Deus que, com sua força, determina o curso da história do mundo conforme sua vontade..$^{59}$

De acordo com Alexandre Rofé, ${ }^{60}$ historiografia é, antes de tudo, uma investigação do passado - "como realmente aconteceu" - e, depois, uma investigação das causas desses acontecimentos, na tentativa de explicá-los. Esse

\footnotetext{
${ }^{57}$ Liver, Jacov. המקרא והמקורות ההיסטוריים שבו (A Bíblia e as suas Fontes Históricas). In: A História do Povo Judeu, Volume II; Os Patriarcas e os Juízes, Am Oved, Tel Aviv, 1967, pp. 31-32.

${ }^{58}$ Idem.

${ }^{59}$ Guttman, Julius. Philosophie des Judentums (em hebraico). Tradução para o hebraico: Baruch, I. L., Bialik, Jerusalém, 1951, p. 13; Grant, Michael. The History of Ancient Israel, Weidenfeld e Nicolson, Londres, 1996, p. 168.

${ }^{60}$ Rofé, Alexander. ההיסטוריוגרפיה הנבואית, (A Historiografia Profética). In: Histórias dos Profetas, Ed.: Magnes, Jerusalém, 1983, p. 68-69.
} 
tipo de registro possibilita a escolha do material que deve ser incluído ou excluído da obra final.

A literatura histórica - que apresenta os acontecimentos de forma clara, bem como a explicação dos seus motivos e o seu desenvolvimento - está presente na narrativa que relata a trajetória dos reis Davi e Salomão e na descrição que segue nos livros de Samuel e Reis. Assim, a maioria dos estudiosos afirma que Israel possui uma literatura histórica e uma tradição de relato histórico, a partir dos dias de Davi e Salomão. ${ }^{61}$

A trajetória dos reinos de Israel e Judá, desde a cisão até a destruição de Judá, é relatada nos livros de Reis e Crônicas. Os redatores dos livros basearam-se em fontes mais antigas. O redator de Reis fez somente pequenas modificações no texto dessas fontes, enquanto que o redator de Crônicas adaptou-as para que fossem compreendidas pelo povo da sua época. ${ }^{62}$

Os livros de Reis e Crônicas foram escritos a partir de fontes diferentes, por autores diferentes, em épocas diferentes.

\footnotetext{
${ }^{61}$ Tadmor,Hayim. ימי הבית הראשון ושיבת ציון (O Período do Primeiro Templo e o Retorno a Sião). In: History of the Jewish People, The Ancient Times. Ed.: Ben Sasson Hayim Hilel, Devir, Tel Aviv, 1969, p. 111.

${ }^{62}$ Idem.
} 


\subsubsection{Reis}

A narrativa histórica dos livros Josué, Juízes, Samuel e Reis é tão similar lingüística e teologicamente ao Deuteronômio que, a partir de meados do século 20 a.e.c., muitos pesquisadores começaram a chamá-la de História Deuteronomística. ${ }^{63}$

Essa História expressa a ideologia do movimento religioso que tem início em Judá nos dias do rei Josias, com a descoberta do livro Deuteronômio por Helcias. ${ }^{64}$ Não há como determinar, realmente, se esse sacerdote descobriu o livro durante a reforma do Templo, conheceu o livro e o trouxe ao conhecimento público no momento que considerou apropriado, ou, até, se ele mesmo escreveu o livro.

Alguns acham que foi escrito na Diáspora, na tentativa de explicar a tragédia da destruição de Jerusalém e do Templo e para manter a identidade do povo no exílio. Outros acreditam que foi escrito nos dias do rei Josias, principalmente para servir à sua ideologia, como também às suas ambições territoriais, e que foi concluído posteriormente, na Diáspora. ${ }^{65}$

\footnotetext{
${ }^{63}$ Neeman, Nadav. לשחזור ההיסטוריה הקדומה של עם ישראל: מקרא, ארכיאולוגיה וכתיבת היסטוריה (Para a Reconstituição da História Antiga do Povo de Israel: Bíblia, Arqueologia e Escrita da História), Zemanim 94, Jerusalém 2006, pp. 8-19; Finkelstein, Israel; Silberman, Niel Asher. The Bible Unearthed Archaeology's New Vision of Ancient Israel and the Origin of its Sacred Texts (em hebraico), Tel Aviv University, Tel Aviv, 2003, pp. 3031; Lipschits, Oded. Jerusalem Between Destruction and Restoration - Judah under Babylonian Rule (em hebraico), Yad Ben-Zvi, Jerusalém, 2004, p. 309-342.

${ }^{64}$ Kaufman, Yehezkel, A Religião de Israel do Início ao Exílio Babilônico, Perspectiva, São Paulo, 1989, pp. 172, 173: "A história da reforma de Josias contém dois elementos: as medidas contra a idolatria e as medidas tomadas contra o culto dos lugares altos, inclusive a centralização do sacrifício pascal em Jerusalém. Essa parece ter sido uma grande inovação (2Rs 23-21ss). Nada se pode saber, por intermédio das medidas contra a idolatria, quanto ao livro que inspirou a reforma, visto que todas as partes de nossa Torá atual denunciam, a idolatria. Mas os lugares altos são interditados explicitamente apenas no livro do Deuteronômio. Baseado nisso, De Wette, no começo do século passado, concluiu que o livro de Josias era o Deuteronômio. Essa opinião passou a dominar o campo da crítica bíblica."

${ }^{65}$ Bright, John. História de Israel, $7^{\mathrm{a}}$ edição, Paulus, São Paulo, 2003, pp. 281-282; Hoffman, Yair. Aspects of Modern Biblical Criticism (em hebraico), Ministry of Defense, Israel 1997, pp. 68-74; Rofé, Alexander. Introduction to the Composition of the Pentateuch, Sheffield Academic Press, Londres, 1999, pp. 62-83; Finkelstein, Israel and Silberman, Neil Asher. The Bible Unearthed, Archaeology's new Vision of Ancient Israel and the Origin of its Sacred Texts (em hebraico), Tel Aviv University, Tel Aviv, 2003, pp. 22-44; Tadmor, Hayim. מי הבית הראשון ושיבת ציון, (O Período do Primeiro Templo e o Retorno a Sião). In: History of the Jewish People, The Ancient Times. Ed.: Ben Sasson, Hayim Hilel, Dvir, Tel Aviv, 1969, pp. 110-114; Neeman, Nadav. לשחזור ההסטוריה הקדומה של עם ישראל, מקרא, ארכיאולוגיה וכתיבת הסטוריה, (Para a Reconstituição da História Antiga do Povo de Israel, Bíblia, Arqueologia, e a Escrita da História), Zemanim 94, 2006, pp. 8-19; Noth, Martin. The Deuteronomistic History, Sheffield, Academic Press, Londres, 1981, pp. 4-11, e outros.
} 
A História Deuteronomística apresenta uma cronologia organizada e linear dos acontecimentos que envolveram o povo de Israel desde a antiguidade. Além disso, contém detalhes que não se propõem a fortalecer nenhuma ideologia, senão apresentar de forma organizada e contínua a história desse povo no decorrer das gerações. $^{66}$

As fontes utilizadas pelo redator do livro são variadas. Três delas são mencionadas no próprio livro: ${ }^{67}$

1. "O livro da história de Salomão."68 A partir desse antigo livro, foram extraídos os trechos que relatam a sabedoria de Salomão como, por exemplo, 1Rs 3:4-15, 1628; porém, é bem provável que esse livro contivesse também documentos oficiais do reinado, ligados à administração, construção e economia.

2. Livro dos "Anais dos Reis de Israel."69 $\mathrm{O}$ autor desse livro conclui o relato sobre cada rei de Israel com as palavras que formam o nome dessa própria fonte. As únicas exceções são os relatos dos reinados de Jorão e Oséias, que não terminam com essa mesma frase.

3. "Livro dos Anais dos Reis de Judá." ${ }^{\text {N0 }}$ Noxto do encerramento da história de quase todos os reis de Judá - com exceção das de Joacaz, Joaquim e Sedecias - o redator conduz o leitor a esse livro.

\footnotetext{
${ }^{66}$ Neeman, Nadav. לשחזור ההסטוריה הקדומה של עם ישראל, מקרא, ארכיאולוגיה וכתיבת הסטוריה, (Para a Reconstituição da História Antiga do Povo de Israel, Bíblia, Arqueologia, e a Escrita da História), Zemanim 94 , 2006, pp. 8-19.

${ }^{67}$ Bustenai, Oded. מבוא לספר מלכים: המקורות של ספר מלכים (Introdução ao livro de Reis: as Fontes do livro Reis). In: עולם התנ"ד (O Mundo da Bíblia), Volume 1 Reis. Ed.: Haran, Menhem, Divrei Hayamim, 1983-1996. Disponível em: <http://lib.cet.ac.il/pages/item.asp?item=9463> (acesso em: 23/04/2008 ); Tadmor, Hayim. (O Período do Primeiro Templo e o Retorno a Sião). In: History of the Jewish People, The Ancient Times. Ed.: Ben Sasson, Hayim Hilel. Dvir, Tel Aviv, 1969, pp. 110-114; Ben-Tor, Amnon. Archaeology-Bible-History (em hebraico). In: The Controversy over the Historicity of the Bible. Ed.: Lee Israel Levin e Mazar Amihai, Yad Ben Zvi e Dinur Center, Jerusalém, 2001, p. 25.

68 1Rs 11:41 Bíblia de Jerusalém, 2003, p 488.

${ }^{69}$ 1Rs 14:19 Bíblia de Jerusalém, 2003, p 492.

${ }^{70}$ 1Rs 14:29 Bíblia de Jerusalém, 2003, p 492.
} 
O Livro das Crônicas dos Reis de Israel e o Livro das Crônicas dos Reis de Judá são, provavelmente, redações baseadas em documentos oficiais da corte dos reis. ${ }^{71}$ Isso pode ser observado nas versões de encerramento da história de cada rei. Por exemplo: "Quanto aos demais atos de Ezequias, todo o seu poder e como ele fez a represa e o aqueduto, trazendo a água à cidade, estão registrados no Livro das Crônicas dos Reis de Judá."72

Esses livros foram as crônicas oficiais dos reinos, como as crônicas dos reis da Assíria e da Babilônia, e relatavam as ações "monumentais" dos reis, além das guerras das quais participaram (Tadmor. H., 1969, p.112). Não há como saber quem os escreveu, ou como e quando foram escritos; mas fica claro que a população da época conhecia o seu conteúdo.

O Livro das Crônicas dos Reis de Israel aparece pela última vez no trecho que trata do rei Pecéia, filho de Romelias. ${ }^{73}$ Provavelmente, o livro foi escrito numa época próxima à conquista do reino de Israel pelos assírios.

Já o Livro das Crônicas dos Reis de Judá aparece pela última vez no trecho que trata do rei Joaquim. ${ }^{74}$ Depreende-se, portanto, que o livro foi escrito, possivelmente, quando da conquista de Jerusalém e da destruição do Templo pelos Babilônios.

\footnotetext{
${ }^{71}$ Tadmor, Hayim. ימי הבית הראשון ושיבת ציון (O Período do Primeiro Templo e o Retorno a Sião). In: History of the Jewish People, The Ancient Times. Ed.: Ben Sasson, Hayim Hilel, Dvir, Tel Aviv, 1969, pp. 110-114.

${ }^{72}$ 2Rs 20:20 Bíblia Hebraica, 2006, p 389. Esse versículo aparece assim em hebraico: "ויתר דברי חזקיהו וכל גבורתו ואשר עשה את הברכה ואת התעלה ויבא את המים העירה הלא הם כתובים על ספר דברי הימים למלכי "יהודה Na Bíblia de Jerusalém, 2003, p. 537, 538, está assim traduzido: "O resto da história de Ezequias, todas as suas façanhas, e como construiu o reservatório e o aqueduto para levar água à cidade, não está tudo escrito no livro dos anais dos reis de Judá?" No Dicionário Hebraico-Português de Berezin, Rivka, USP, SP, 2003, p. 133, a palavra הלא "ha-lo" tem a seguinte tradução: "em verdade, mas, pois." No The Complete Hebrew-English Dicionary, de Alcalay, Reuben, Massada Publishing, Tel Aviv 1965, p. 527, a tradução de הלא é: "surely". Por isso, para a citação acima escolhemos usar a tradução de Fridlin, Jairo e Gorodovits, David, em: "Bíblia Hebraica", Ed.: Sêfer, SP, 2006 p. 389.

${ }^{73}$ 2Rs 15:31.

${ }^{74}$ 2Rs 24:5.
} 
Além desses livros, há também a inclusão, em Reis, de histórias sobre profetas. Elas trazem a figura do homem de Deus - o profeta - e não a do rei da época, como figura central. ${ }^{75}$ Essas histórias foram passadas, oralmente, de geração em geração, ${ }^{76}$ e é possível que algumas delas tenham até sido escritas. O autor de Reis precisou dessas histórias para descrever, por um lado, as batalhas dos profetas contra os reis e contra o culto idólatra e, por outro, a salvação que os profetas trouxeram para o povo de Israel, quando seguiu o caminho de Deus.

Outra fonte usada nos relatos em Reis são os arquivos do Templo, que continham assuntos do próprio Templo e descrições dos grandes acontecimentos que o atingiram, ${ }^{77}$ como, por exemplo, as reformas físicas de sua construção, a reforma do culto e o destino do tesouro do Templo. ${ }^{78}$

As fórmulas de abertura e de conclusão do relato sobre cada rei incluem, normalmente, dados sobre os reis e marcos cronológicos. Em muitas dessas fórmulas o redator acrescentou comentários de juízo sobre o rei. O critério usado foi principalmente o culto. ${ }^{79} \mathrm{O}$ redator deu importância aos reis que promoveram reformas no culto, aumentaram a importância do Templo e destruíram altares durante seu reinado. Essa tendência condenou os reis de Israel, que se afastaram do Templo de Jerusalém e com isso: "fizeram... o mal na presença de lahweh." 80

Ao direcionar o leitor a textos anteriores, que descrevem as ações dos reis e suas guerras, o redator demonstra que não determinou sua narração a partir da

\footnotetext{
${ }^{75}$ O profeta Elias: 1Rs 17-19 e 2Rs 1-2; O profeta Eliseu: 2Rs: 2-13.

${ }^{76}$ 2Rs 8:7.

77 Rs 22.

${ }^{78}$ A Jornada do Faraó Sisaque para Jerusalém, nos dias de Roboão, e a descrição dos bens do Templo que lhe foram entregues, 1Rs 14:25-27, o ouro e a prata que foram entregues por Ezequias para Senaquerib, o rei de Assíria, 2Rs 18:14-16.

79 Garsiel, Moshe. מבוא לספר מלכים: מבנה הספר תוכנו ומגמתו (Introdução ao livro de Reis: sua Estrutura, seu Conteúdo e sua Tendência), in: עולם התנמה: (O Mundo da Bíblia), Volume 1 Reis. Ed.: Haran, Menhem, Divrei Hayamim, 1983-1996. Disponível em: <http://lib.cet.ac.il/pages/item.asp?item=9464> (acesso em: 23/04/2008).

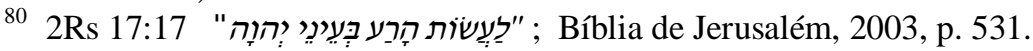


construção do reino, ou das ações sociais ou político-militares dos reis. Como exemplo, pode-se mencionar o fato de que a guerra contra o rei assírio, da qual Acab participou, não foi relatada no livro, apesar de sua enorme importância para toda a região.

A escolha dos assuntos tratados no livro, a ênfase dada ao culto no Templo, as fórmulas de abertura e de conclusão e os comentários de juízo, demonstram claramente o seu objetivo: manter as leis de Deus e realizar, corretamente, o seu culto.

Nesse livro, os pontos de maior relevância são: a concentração do culto em Jerusalém e a promessa de eternidade para a casa de Davi. ${ }^{81}$ Por isso, a construção do Templo e a celebração do serviço sagrado dentro dele, são apresentadas como as ações mais significantes do rei Salomão. Os reis relatados como os mais admiráveis no reino de Judá são Ezequias $^{82}$ e Josias $^{83}$, que elevaram a importância de Jerusalém e do Templo.

Apesar disso, destacam-se o aumento de culto idólatra e dos atos de tirania dos reis. Esses atos - pecados - seriam a causa dos castigos sofridos pelo povo, com a divisão do Reino Unido e a destruição do reino de Israel e do reino de Judá. Assim, o redator explica a razão para que Deus tenha levado às ultimas conseqüências Seu pacto com Seu povo, levando-o ao exílio.

Dessa descrição histórica, podemos aprender alguns pontos cruciais a respeito da tradição e da cultura do povo judeu: o direito de habitar a terra de Israel; a importância de Jerusalém; a eternidade da casa de Davi frente às famílias

\footnotetext{
81 Lipschits, Oded. Jerusalem Between Destruction and Restoration - Judah under Babylonian Rule, (em hebraico), Yad Ben-Zvi, Jerusalém, 2004, pp. 309-342.

82 2Rs trata do reinado de Ezequias nos capítulos 16:20, 18:1-37, 19:1-37, 20:1-21, 21:3.

83 2Rs 22-23. O redator de Reis descreve, detalhadamente, a descoberta do livro da Lei nos dias de Josias.
} 
sacerdotais; as relações entre a Diáspora e a terra de Israel e a importância de morar em Israel. ${ }^{84}$

\footnotetext{
${ }^{84}$ Vide nota 81.
} 


\subsubsection{Crônicas}

O livro de Crônicas provavelmente foi redigido no final do domínio Persa, na segunda metade do século 4 a.e.c., alguns séculos após os acontecimentos nele descritos. $^{85}$

É uma narrativa que traz o ponto de vista do Cronista, que objetiva glorificar o rei Davi como o rei ideal, cujo reinado e dinastia são os únicos considerados legítimos. ${ }^{86}$ Assim, apresenta parte dos pensamentos e crenças da época do segundo Templo, na linguagem compreendida naquele período.$^{87} \mathrm{O}$ Cronista atribui enorme importância ao culto celebrado no Templo. Em Crônicas, há muito mais passagens relatando o cerimonial do Templo, sua ordem e sua organização, do que em Reis. Muitos desses detalhes combinam com a realidade da época do segundo Templo. ${ }^{88}$

Ao contrário do ponto de vista de Reis, que entendia o pecado de alguns reis, como a razão do severo castigo - a destruição do Templo e o exílio do povo - o redator de Crônicas acredita em castigo ou recompensa imediatos, que recaem individualmente e de acordo com os atos de cada pessoa. Seguindo esse

\footnotetext{
${ }^{85}$ Japhet, Sara. ההיסטוריה של עם ישראל, שיבת ציון - ימי שלטון פרס, ההיסטוריוגרפיה המקראית בתקופה הפרסית (A História do Povo de Israel, O Retorno a Sião - o Período do Domínio Persa, a Historiografia Bíblica na Época Persa) Am Oved, Jerusalém, 1983, p. 199; Finkelstein, Israel e Silberman, Niel Asher. The Bible Unearthed Archaeology's New Vision of Ancient Israel and the Origin of its Sacred Texts (em hebraico), Tel Aviv University, Tel Aviv, 2003, p. 31; Tadmor, Hayim. מי הבית הראשון ושיבת ציון (O Período do Primeiro Templo e o Retorno a Sião). In: History of the Jewish People, The Ancient Times. Ed.: Ben Sasson, Hayim Hilel. Devir. Tel Aviv, 1969, p. 111.

${ }^{86}$ Maguidov, Rony, היסטוריוגרפיה (Historiografia), Mikranet, 2005. Disponível em: <http://lib.cet.ac.il/ pages/ item.asp?item=13168 \&kwd=4024> (acesso em 22/05/2008.)

87 Zakovitch, Yair em. ספר דברי הימים כפרשן - מבוא לפרשנות פנים מקראית Crônicas como Comentarista - Introdução aos Comentários Intra-Bíblicos), Reches, 1992. Disponível em: <http:// mikranet.cet.ac.ul /pages/item.asp ?item=7641> (acesso em 01/05/2008), apresenta alguns exemplos dessas diferenças: em 1Rs 10:18 está escrito: "זהב מופז" (ouro puro); no texto correspondente em 2Cr 9:17 está escrito " זהב טהור" (ouro puro); em 2Sm 23:13 está escrito "וחית פלישתים" (acampamento dos filisteus); no texto correspondente em 1Cr 11:15 está escrito: "מדתנה פלישתים" (acampamento dos filisteus).

${ }^{88}$ Bustenai, Oded. ירושלים לדורותיה: מעיר יבוסית לבירת עם ישראל (Jerusalém e suas Gerações: de Cidade Jebusita à Capital do Povo de Israel), Open University, Tel Aviv, 1984, pp. 37,38.
} 
pensamento, filhos não podem ser castigados por pecados cometidos por seus pais. $^{89}$

O Cronista acredita que não é cabível que um rei tenha pecado e que outro rei sofra o castigo. Cada reinado recebe castigo ou recompensa de acordo com sua essência. Assim, os acontecimentos apresentados em 2Rs 23:24-27 - o pecado do rei Manassés versus a "bondade" de Josias - não são mencionados em Crônicas. ${ }^{90}$

Dessa forma, também, o maior castigo, a destruição de Judá, é apresentada em Crônicas como castigo pelos atos de um único rei - Sedecias - e não pelos pecados acumulados por todas as gerações anteriores.

"De acordo com o seu conteúdo e a sua estrutura, Crônicas está dedicado à descrição da história do povo de Israel, desde o começo, com a criação do homem, até o novo começo, a declaração do rei Ciro. É uma descrição de essência política definida e contínua, tanto no aspecto do tema, como no do tempo e do lugar.,"91

O espaço de tempo e a descrição histórica que o livro abrange são paralelos àqueles descritos no Pentateuco e nos livros Josué, Juízes, 1 e 2 Samuel e 1 e 2 Reis. É composto, em grande parte, de citações desses livros, sem modificações ou com pequenas variações dos originais.

Assim, quando a narrativa em Crônicas se afasta do texto original, pode-se entender o significado do distanciamento a partir de uma comparação entre as fontes, como será explicado a seguir.

\footnotetext{
${ }^{89}$ Esse pensamento é expresso nas palavras de Ezequiel no período da diáspora na Babilônia. Ele acredita no castigo ou recompensa individuais. "הנפש החוטאת היא תמות" ("Aquele que pecar, esse morrerá" Bíblia de "מה לכם אתם מושלים את המשל הזה על אדמת ישראל לאמור אבות אכלו בוסר "Oterusalém, 2006, p.1503.) Ezequiel 18:4" "Q"Que vem a ser este provérbio que vós usais na terra de Israel: "Os pais comeram uvas verdes e os dentes dos filhos ficaram embotados"?” Bíblia de Jerusalém, 2006, p. 1503.) Ezequiel 18:2.

${ }^{90}$ Talshir, Tzipora. תפיסת פילוג הממלכה בספר מלכים ובספר דברי הימים: תפיסת הפילוג בספר דברי הימים (A Concepção da Cisão em Reis e Crônicas: A Concepção da Cisão em Crônicas), Al Haperek 7, 1994, p. 34.

${ }^{91}$ Japhet, Sara. ספר דיברי הימים, חיבור היסטורי (Crônicas - Redação Histórica), Anuário da Pesquisa Bíblica e do Oriente Antigo, 14, Tanach, Israel, 2004, p. 102.
} 
Em Crônicas, o relato foi determinado por fatores literários, cronológicos e políticos. De acordo com esses mesmos fatores, a narrativa pode ser dividida em três partes: ${ }^{92}$

Primeira parte - 1 Crônicas capítulos 1-9:

Essa parte pode ser considerada como introdução. Nela são apresentadas as bases cronológicas, geográficas e étnicas, que servem de fundamento aos acontecimentos históricos descritos no livro. Esses capítulos respondem algumas perguntas: Quem é o povo cuja história será relatada? Qual é o seu âmbito histórico e onde ele vive?

Os primeiros capítulos de Crônicas apresentam uma junção de listas genealógicas, que também aparecem em outros livros da Bíblia ${ }^{93}$. O cronista não inclui todas as listas genealógicas existentes na Bíblia. Seleciona apenas aquelas que the interessam ${ }^{94}$.

A apresentação detalhada dos indivíduos e sua genealogia demonstram que o povo de Israel, em sua essência, é uma unidade composta de doze tribos.

O panorama geográfico descrito é a comprovação necessária para a habitação do povo inteiro, dentro do território inteiro que é "ארצות ישראל" (todas as terras de Israel) 1Cr 13:2. As suas fronteiras são: "מן שיחור מצרים ועד לבוא חמת" (desde o Sior, do Egito, até a entrada de Hamate) 1Cr 13:5. Essa constatação é atingida ao descrever cada tribo com o seu respectivo território.

\footnotetext{
92 Japhet, Sara. ה ההיסטוריה של עם ישראל, שיבת ציון - ימי שלטון פרס, ההיסטוריוגרפיה המקראית בתקופה הפרסית (A História do Povo de Israel, o Retorno a Sião - o Período do Domínio Persa, Historiografia Bíblica na Época Persa) Am Oved, Jerusalém, 1983, pp. 176-203.

${ }^{93} 1 \mathrm{Cr} 1$, apresenta todos as listas genealógicas que aparecem em Gênesis.

${ }^{94}$ De Josué ele escolhe somente duas listas, as que descrevem as cidades de Shimon (Josué 19:1-8 aparecem em $1 \mathrm{Cr}$ 4:28-33) e as que descrevem as cidades dos Levitas (Josué 21: 1-42 aparecem em 1Cr 6: 40-66).
} 
As instituições responsáveis pelo culto são apresentadas como extremamente organizadas, cumprindo suas funções de forma correta (2Cr 6:19-33), fato considerado importante na descrição histórica, a partir dos dias do rei Davi, mas que tem raízes muito mais antigas, como demonstrado pelo Cronista nesse livro.

A percepção histórica do livro é muito peculiar. Existe uma continuidade, sem intervalos, da presença do povo de Israel em Canaã, desde os filhos de Jacó até o rei Davi. Não há qualquer relato da ida ao Egito, ou da escravidão, da saída do Egito, ou da conquista e do assentamento em Canaã.

Com isso, o Cronista apresentou o seu parecer sobre a natureza da escolha do povo de Israel, bem como sobre a essência de sua ligação com a terra de Israel. Não há uma promessa num momento histórico específico e sua realização em outro, mas tão somente a existência do povo eleito e a continuidade perene de seu assentamento.

Segunda parte - 1 Crônicas capítulo 10 a 2Cr capítulo 9:

A segunda parte mostra a história do estabelecimento dos reinados de Davi e de seu filho Salomão, época considerada como a era gloriosa do reino. Os dois reis foram apresentados como paralelos que se complementam. Davi inicia as ações e Salomão as completa.

A descrição da vida de Davi foi feita principalmente a partir do relato em Samuel, do qual o Cronista copiou capítulos inteiros; mas, fazendo algumas modificações, construiu uma nova concepção do rei Davi. ${ }^{95}$ Um Davi isento de

\footnotetext{
${ }^{95}$ Em Crônicas não aparecem os relatos sobre Davi e Bate-Seba, ou o que é feito com seu marido - Urias $2 \mathrm{Sm}$ 11; do estupro que sofreu Tamar pelo seu irmão Amnon 2Sm 13:14 ou da revolta de Absalão 2Sm 15:10. Japhet, Sara. ההיסטוריה של עם ישראל, שיבת ציון - ימי שלטון פרס, ההיסטוריוגרפיה המקראית בתקופה הפרסית (A História
} 
pecados irreparáveis, em sua trajetória, e cujo reinado é considerado exemplar. ${ }^{96} \mathrm{O}$ Cronista acrescentou à trajetória de Davi mais ações sociais e religiosas, além de discursos e orações repletos de espírito religioso e devoção a Deus e a seu povo.

E, igualmente, tratou Salomão. Foram retiradas da história todas as intrigas do início e a decadência religiosa ao final do reinado de Salomão. O Cronista acrescentou, ainda, características que se destinaram a engrandecer a imagem de Salomão.

Terceira parte - 2Cr capítulos 10-36:

$\mathrm{Na}$ terceira parte, há uma descrição dos reis do reino de Judá que são descendentes de Salomão, de Roboão até Sedecias. Não existe relato dos reis do reino de Israel, pois, de acordo com o Cronista, o povo de Israel tem um único reinado legítimo - o reino de Judá, com os descendentes do rei Davi. ${ }^{97}$ Assim, o Cronista trouxe todos os eventos comuns aos dois reinos, sem narrar a história específica do reino de Israel. Ele considerou o povo do reino do norte como parte integrante do povo de $\left.\right|_{\text {srael }} ^{98}$.

A fonte empregada nessa parte é o relato descrito em Reis, com uma adaptação útil à visão do Cronista. Nessa adaptação, podemos perceber algumas regras:

do Povo de Israel, o Retorno a Sião - o Período do Domínio Persa, Historiografia Bíblica na Ėpoca Persa) Am Oved, Jerusalém, 1983, p. 193.

${ }^{96}$ Maguidov, Rony. היסטוריוגרפיה (Historiografia), Mikranet, 2005, disponível em: <http://lib.cet.ac.il/pages /item.asp?item=13168 \&kwd=4024> (acesso em 22/05/2008,)

${ }^{97} 2 \mathrm{Cr} 13: 5-12$

${ }^{98}$ Japhet, Sara. התיסטוריה של עם ישראל, שיבת ציון - ימי שלטון פרס, ההיסטוריוגרפיה המקראית בתקופה הפרסית (A História do Povo de Israel, o Retorno a Sião - o Período do Domínio Persa, Historiografia Bíblica na Ėpoca Persa) Am Oved, Jerusalém, 1983, pp. 176-203 
1. Por pecados cometidos propositadamente, há castigo, e, por boas ações, há recompensa. Assim, se em suas fontes existia a descrição de um ato sem resposta imediata, o Cronista acrescentou-Ihe uma.

2. Qualquer desastre é apresentado como castigo e qualquer sucesso pessoal ou público - é apresentado como recompensa. Se o redator de Reis não descreveu as boas ações antes da recompensa, ou deixou de citar o pecado antes do castigo, o Cronista tratou de intercalá-los.

3. Com isso, o Cronista criou relações de causa e efeito entre os acontecimentos.

O fato de que cada geração recebe seu castigo ou recompensa imediatamente, afasta o Cronista da idéia expressa em Reis, de que há acúmulo de pecados durante gerações, o que implicaria em castigo muito grande.

Em Crônicas, aparecem muitas descrições de vários aspectos da vida política. O Cronista relata, com detalhes, a organização do exército e suas armas, as formas da administração, as construções, a atividade econômica e outros. ${ }^{99}$

Crônicas é um livro que apresenta uma continuação literal tradicional de Reis, sendo, entretanto, completamente diferente. Não foi escrito para que o leitor pudesse entender determinado acontecimento, ou fato histórico, mas, sim, para entender que a ordem dos acontecimentos históricos que envolvem o povo de Israel é resultado direto da ação de Deus. Deus é quem supervisiona e dirige o mundo com justiça e a história do povo resulta dessa vigilância. A concepção de justiça nas

\footnotetext{
${ }^{99}$ Idem.
} 
ações de Deus dá ao povo a esperança de dias melhores - uma visão otimista para o futuro da nação. ${ }^{100}$

Aprendemos sobre a trajetória de Ezequias a partir de $1 \mathrm{Cr}$ 3:13; 4:38-43 e de 2Cr 28:27-33:3.

${ }^{100}$ Idem. 


\subsection{Os anais assírios}

As crônicas dos reis assírios tinham como meta engrandecer suas ações. Elas são os escritos oficias do reinado e estão redigidas na $1^{\underline{a}}$ pessoa, para dar a entender que o próprio rei registrou, ano a ano, todos os acontecimentos no reinado. Os textos começam apresentando todos os títulos do rei e terminam com uma lista de todas as suas obras.

A partir do século 11 a.e.c., no reinado de Tiglat Pilasser I, os textos assírios oficiais começam a apresentar as incursões militares e as conquistas pessoais de cada rei, sempre de acordo com os anos de seu reinado. ${ }^{101}$

Os anais são narrativas reais, que utilizam descrições heróicas com qualidades poéticas e empregam formatos repetidos. ${ }^{102}$ Os textos combinam o épico heróico com a crônica, na qual os acontecimentos estão organizados de acordo com os anos de reinado de cada governante. Além disso, havia necessidade de mostrar a grandiosidade do rei logo no início do seu reinado. Nos anais de Tiglat Pilasser I, por exemplo, uma grande vitória ocorreu em um único dia, no primeiro ano do seu reinado: "Em um terço do dia, depois do nascer do sol.".103

Senaquerib, nos séculos 8-7 a.e.c., usou um formato diferente. Em seus anais, aparece a expressão "na minha primeira incursão militar" e não "no primeiro ano do reinado." Esse novo formato trouxe a possibilidade de relatar os acontecimentos em ordem cronológica de maneira mais exata. Assim, a grandiosidade do rei foi avaliada levando em conta a quantidade de suas incursões militares. Seus anais descrevem

\footnotetext{
${ }^{101}$ Tadmor, Hayim. Assyria, Babylonia and Judah (em hebraico). Ed.: Cogan Mordechai, The Bialik Institute, Jerusalém, 2006, pp. 1, 2.

${ }^{102}$ Idem, p. 6.

${ }^{103}$ Idem, p. 26.
} 
todas as guerras das quais participou, detalhando os anos em que ocorreram, os nomes dos reis inimigos derrotados e as listas de presentes e tributos que foram obrigados a pagar ao rei assírio. ${ }^{104}$

Os anais serviram para expressar a ideologia real e mostrar os reis como seguidores devotos dos deuses. Reis que dedicam todas as suas ações para engrandecer os deuses e agem de acordo com as exigências divinas. Além disso, os relatos da suma importância de cada rei, de sua crueldade nas conquistas e dos enormes impostos recolhidos dos inimigos derrotados tinham como objetivo manter os povos conquistados amedrontados, para que não tentassem rebelar-se contra a Assíria. ${ }^{105}$ 
Capítulo 2: Povos vizinhos do reinado de Ezequias

\subsection{Filistéia}

As cidades filistéias desenvolveram-se ao longo do "Caminho do Mar"106, uma estrada 'internacional' que ia da Síria e do Líbano ao Egito, localizada na faixa costeira a 4-6 quilômetros do mar. Entre elas, havia cidades portuárias com um desenvolvido comércio marítimo. ${ }^{107}$

Essa estrada era passagem obrigatória dos exércitos e dos comboios comerciais que iam do Egito a Israel, Síria e Mesopotâmia, e vice-versa. O caminho foi utilizado, também, pelos exércitos que lutaram contra os filisteus. ${ }^{108}$

As grandes cidades Filistéias foram divididas em três grupos: As cidades da faixa costeira: Ashkelon e Yaffo que se tornaram as principais cidades costeiras em Canaã, com o principal acesso por via marítima; cidades que se localizavam a pouca distância do mar com acesso marítimo e terrestre: Gaza, Ashdod e lavne; e cidades distantes do mar: Ekron e Gat. ${ }^{109}$

Essas últimas cinco desempenharam um papel fundamental no comércio 'internacional' entre Arábia, Egito e Fenícia e, assim, obtiveram grande poder

\footnotetext{
${ }^{106}$ Is 8:23, Bíblia de Jerusalém, 2003, p. 1268.

107 Aharoni, Yohanan. The Land of Israel in Biblical Times a Historical Geography (em hebraico), The Bialik Institute, Jerusalém, 1962, pp. 32-42; Kitchen, Kenneth Anderson. The Philistines. In: Peoples of the Old Testament Times. Ed.: Wiseman, Donald John, Oxford University Press, 1973, pp. 53-78.

${ }^{108}$ Idem

${ }^{109}$ Kitchen, Kenneth Anderson. The Philistines. In: Peoples of the Old Testament Times. Ed.: Wiseman, Donald John, Oxford University Press, 1973, pp. 53-78.
} 
econômico e mantiveram o controle do "Caminho do Mar." Por isso tiveram poucos períodos de paz. ${ }^{110}$

Os filisteus organizaram-se num tipo de confederação, constituída por cinco Cidades-Estado: Ashkelon, Ekron, Gaza, Gat e Ashdod, nas quais ficavam os governantes-reis, que geralmente eram militares.

Durante 150 anos, nos séculos 11 e 10 a.e.c., os filisteus foram a principal força de Canaã, devido à sua ótima organização militar dentro da confederação, aos métodos avançados de guerra e ao seu equipamento militar. Esse último é bastante visível nos relevos egípcios, que mostram o guerreiro filisteu equipado com armas de ferro, cujo segredo de fabricação os filisteus guardavam a sete chaves. ${ }^{111}$

${ }^{110}$ Tadmor, Hayim. Assyria, Babylonia and Judah (em hebraico). Ed.: Cogan Mordechai, The Bialik Institute, Jerusalém, 2006, pp. 229-232.

${ }^{111}$ Aharoni, Yohanan. The Land of Israel in Biblical Times a Historical Geography, (em hebraico), The Bialik Institute, Jerusalém, 1962, pp. 230-238; Grant, Michael. The History of Ancient Israel, Weidenfeld e Nicolson, Londres, 1996, pp. 67-70. 


\subsubsection{Revoltas internas nas cidades filistéias}

Nos dias dos reis Acaz e Ezequias, a história das cidades filistéias foi caracterizada por rebeliões e derrubadas de governos.

Em Ashdod, houve disputas entre a dinastia que estava no poder e os militares que queriam lutar contra o jugo da Assíria. Numa revolta militar do final de 713 a.e.c., o rei Ahimot, vassalo assírio, foi deposto e substituído por um plebeu denominado Yamani. ${ }^{112}$

Em Ashkelon, Zidká - partidário da revolta contra Assíria - tomou o poder das mãos do rei Ruchibti - que era leal aos reis assírios. Zidká é mencionado na inscrição de Senaquerib, de 701 a.e.c., como um rei inimigo da Assíria. Disso podemos deduzir que ele era aliado de Ezequias - que talvez o tenha ajudado a assumir o governo de Ashkelon. ${ }^{113}$

O envolvimento de Ezequias nas revoltas que derrubaram governos nas cidades filistéias destaca-se especialmente em Ekron. Ele ajudou os ministros da cidade - que queriam rebelar-se contra a Assíria - a derrubar seu rei, vassalo leal dessa. Senaquerib relata que castigou os ministros de Ekron:

"... I approached Ekron and slew the governors and nobles who had rebelled, and hung their bodies on stakes around the city. The inhabitants who rebelled and treated (Assyria) lightly I counted as spoil."114

Ezequias aproveitou a fragilidade de Ekron, apoiou os nobres e, assim, conseguiu que os governantes da cidade dele dependessem. ${ }^{115}$

\footnotetext{
${ }^{112}$ Bustanai, Oded. יהודה ואשור (Judá e Assíria), Open University, Tel Aviv, 1984, pp. 6-10.

${ }^{113}$ Idem

${ }^{114}$ Luckenbill, Daniel David. The Annals of Sennacherib. Oriental Institute Publications 2, University of Chicago Press, Chicago, 1924, pp. 27-31, coluna 3, linhas 9-11.
} 


\subsection{Assíria}

O Império Assírio dominava a região do Oriente Próximo Antigo durante os séculos 9 a 7 a.e.c. Os reis assírios mantiveram o império com um aparato militar gigantesco e conhecimento tecnológico baseado numa estrutura administrativa bem desenvolvida. ${ }^{116}$

O profeta Isaías assim descreve essa força:

"Ele deu sinal de um povo distante, assobiou-lhe desde os confins da terra; ei-lo que vem chegando apressado e ligeiro. No meio dele não há cansados nem claudicantes, não há nenhum sonolento, ninguém que dormite, ninguém que desate o cinto dos seus lombos, ninguém que rompa a correia de suas sandálias. Suas flechas estão aguçadas e todos os seus arcos retesados, os cascos dos seus cavalos parecem sílex, as rodas dos seus carros lembram furacão. Seu rugido é como leoa, ruge como o leão novo; ruge enquanto agarra sua presa, arrebata-a e não há quem consiga tomar-lha."117

O desenvolvimento de meios para cruzar rios e obstáculos terrestres, como também de instrumentos para sitiar cidades muradas, juntamente com a construção de fortalezas, possibilitou aos reis da Assíria o longo domínio sobre os reinados conquistados. ${ }^{118}$

O sucesso dos assírios foi devido ao fato de que junto com a força militar, os assírios elaboraram uma forma de governo revolucionária nos reinados conquistados. Eles migraram povos para aniquilar a existência desses como entidades independentes, organizaram os territórios ocupados como províncias

\footnotetext{
${ }^{115}$ Bustanai Oded. הודה ואשור (Judá e Assíria), Open University, Tel Aviv, 1984, pp. 6-10.

${ }^{116}$ Malamat Avraham. The Wars of Israel and Assyria (em hebraico). In: The Military History of the Land of Israel in Biblical Times. Ed.: Liver Jacob, Maarachoth, $4^{\mathrm{a}}$ edição, Tel Aviv, 1968, pp. 241-260.

${ }^{117}$ Is, 5:26-29, Bíblia de Jerusalém, 2003, pp.1262, 1263.

${ }^{118}$ Vide nota 116.
} 
assírias e alistaram soldados dos povos invadidos para o seu próprio exército. Assim, eles se precaveram de rebeliões futuras. ${ }^{119}$

Os reis colocaram governantes assírios nos reinados conquistados, que utilizavam seu próprio exército e cobravam impostos em dinheiro, produção agrícola e trabalho. Muitos reis, com medo da forte Assíria, tornaram-se seus vassalos, pagando-Ihe tributos elevados. ${ }^{120}$ Como exemplo, podemos observar a inscrição no Obelisco Negro de Shalmanesser III: ${ }^{121}$ Tribute of Jehu, son of Omri. I received from him: silver, gold, a golden bowl, a golden beaker, golden goblets, pitchers of gold, lead, staves for the hand of the king, javelins. ${ }^{122}$

Mazar ${ }^{123}$ descreve a força dos assírios:

"A ameaça assíria a Israel e seus vizinhos foi sentida pela primeira vez durante o reinado de Acab. Os assírios tinham reunido uma formidável máquina militar e, a partir do início do século nove a.C., começado a conquista sistemática de grande parte do Antigo Oriente Próximo... O perigo da conquista assíria foi tão agudo que, já em meados do século nove a.C., os reis da Síria meridional e da Palestina, inclusive Acab, foram motivados a suspender seus próprios conflitos e formar uma liga anti-assíria."

A expansão territorial da Assíria foi principalmente à Síria no oeste, onde havia muito material de construção como pedras e madeiras nobres. Por ali passavam os caminhos de comércio da Ásia Menor ao Egito e à Arábia. Para garantir um suprimento constante de produtos, a Assíria ampliou seu domínio para o norte e para o sul, Israel. ${ }^{124}$

\footnotetext{
${ }^{119}$ Tadmor, Hayim. Assyria, Babylonia and Judah (em hebraico). Ed.: Cogan Mordechai, The Bialik Institute, Jerusalém, 2006, p. 226.

${ }^{120}$ Malamat Avraham. The Wars of Israel and Assyria (em hebraico). In: The Military History of the Land of Israel in Biblical Times. Ed.: Liver Jacob, Maarachoth, $4^{\mathrm{a}}$ edição, Tel Aviv 1968, pp. 241-260.

${ }^{121}$ Vide anexo 5.

${ }^{122}$ Luckenbill, Daniel David. Ancient Records of Assyria and Babylonia. Volume 1, Chicago: University of Chicago Press, 1927, pp. 200-211.

${ }^{123}$ Mazar, Amihai. Arqueologia na terra da Bíblia - 10.000 - 586 a.C., Paulinas, São Paulo, 2003, p. 387.

${ }^{124}$ Malamat, Avraham. The Wars of Israel and Assyria (em hebraico). In: The Military History of the Land of Israel in Biblical Times. Ed.: Liver Jacob, Maarachoth, $4^{\text {a }}$ edição, Tel Aviv 1968, pp. 241-260.
} 
As incursões militares assírias acabaram com muitos reinados, dentre eles, Aram-Damasco, em 732 a.e.c. aproximadamente, e Israel ${ }^{125}$ (Reino do Norte), em 722 a.e.c., aproximadamente. Alguns reinados conseguiram conservar uma relativa independência, mas mediante pagamento de impostos para o império Assírio. ${ }^{126}$

Ao mesmo tempo em que o império Assírio se manteve como a maior força da região, alguns outros reinos conseguiram fortalecer-se. No oeste - o Egito, no leste - a Babilônia, no nordeste - o reino de Madai, e em Canaã - o reino de Judá. ${ }^{127}$

125 "Shalmanesser, rei da Assíria, atacou a Samaria e a sitiou. No fim de três anos, conquistou-a... O rei da Assíria deportou Israel para a Assíria.” 2Rs 18:9-11, Bíblia de Jerusalém, 2006, p. 532.

${ }^{126}$ Vide nota 124, pp. 255-256.

${ }^{127}$ Mazar Binyamin. Sennacherib's Judean Campaign (em hebraico). In: The Military History of the Land of Israel in Biblical Times. Ed.: Jacob Liver, Maarachot, Tel Aviv, 4ª edição, 1968, pp. 286-288. 
2.2.1 As invasões assírias na Filistéia entre $734-720$ a.e.c. ${ }^{128}$

Nos trinta e cinco anos que antecederam a Jornada de Senaquerib, em 701 a.e.c., as cidades filistéias sofreram ataques dos exércitos assírios, liderados por Tiglat Pilesser III e Saragon II.

Entre 742-738 a.e.c., Tiglat Pilesser III conquistou a Síria e suas cidades costeiras. Dentre os que pagavam tributo para o rei assírio estavam Ratzin, o rei de Damasco; Manaém, de Israel ${ }^{129}$ e Hiram, de Tiro. Os assírios tinham interesse no comércio marítimo da Fenícia e queriam o monopólio das mercadorias comercializadas. ${ }^{130}$

Para conseguir o monopólio, Tiglat Pilesser III seguiu o "Caminho do Mar" até a Filistéia. O domínio sobre todas as cidades costeiras possibilitou o controle do comércio, além de impedir o contato entre os reinados da região, prevenindo possíveis revoltas. ${ }^{131}$

O principal alvo na incursão de 734 a.e.c. foi Gaza, como revelam os anais Assírios. Descrevem a fuga do rei Hanun e a conquista e o saque feitos pelos assírios na cidade. A família real e os deuses da cidade foram capturados e Gaza se

\footnotetext{
${ }^{128}$ As datas constantes deste capítulo estão de acordo com Tadmor, Hayim. Assyria, Babylonia and Judah (em hebraico), Ed.: Cogan Mordechai, The Bialik Institute, Jerusalém, 2006.

129 "Pul, rei da Assíria, invadiu a terra. Manaém pagou a Pul mil talentos de prata para que apoiasse e consolidasse o poder real em suas mãos. Manaém requereu essa quantia de Israel, de todos os notáveis, para dá-la ao rei da Assíria." 2Rs 15:19,20. Bíblia de Jerusalém, 2006, pp. 527-528. "Conforme os documentos assírio-babilônicos, Pûlu é o nome de coroação tomado por Tiglat Pilesser III, rei da Assíria (745-727), quando assumiu o poder na Babilônia em 729." Bíblia de Jerusalém, 2006, nota de rodapé f, pp. 527-528.

${ }^{130}$ Tadmor, Hayim. Assyria, Babylonia and Judah (em hebraico). Ed.: Cogan Mordechai, The Bialik Institute, Jerusalém, 2006, pp. 231-232.

${ }^{131}$ Tadmor Hayim. The Assyrian Campaigns to Philistia. In: The Military History of the Land of Israel in Biblical Times. Ed.: Liver Jacob, $4^{a}$ edição, Maarachoth, Tel Aviv, 1968, p. 264.
} 
tornou vassala Assíria, continuando a exercer sua função de maior cidade portuária da região, próxima ao Egito. ${ }^{132}$

Em 732 a.e.c., a lista dos reis que pagavam tributos para a Assíria inclui Mitinti, de Ashkelon; Acaz, de Judá; Hanun, de Gaza; como também os reis de Amon, Moab e Edom. ${ }^{133}$

Com a morte de Tiglat Pilesser III, a maioria dos reinados da Síria e de Canaã, incluindo o de Gaza, rebelou-se contra a Assíria, o que levou Saragon II, o sucessor do falecido rei assírio, a uma incursão militar devastadora na região, em 720 a.e.c.

Como resultado, o rei de Gaza foi levado prisioneiro e sua cidade tornou-se vassala da Assíria, não mais se rebelando contra ela. Gaza continuou a servir de principal porto para as mercadorias vindas da Arábia e os dois reinos tiraram proveito da situação. A Assíria - que através do controle do porto em Gaza tentou controlar também a Arábia - e Gaza - que continuou obtendo lucros altos desse comércio. $^{134}$

O rei de Ashdod, Yamani, rebelou-se em 712 a.e.c. e convocou outras cidades filistéias, bem como os reinos de Judá, Edom e Moab, a se juntar para expulsar a Assíria da região. Mas somente Ekron atendeu ao chamado. No caminho para Ashdod, Saragon II com seu exército capturou Ekron. Como resultado desta incursão militar, a Assíria transformou Ashdod em província e, com isso, aproximouse da fronteira egípcia. ${ }^{135}$

\footnotetext{
${ }^{132}$ Vide nota 127 , pp. 232-233.

133 Idem, p. 234.

${ }^{134}$ Idem, pp. 236-238.

${ }^{135}$ Saragon II deixou uma estela em Ashdod, que descreve sua vitória naquela cidade em 712 a.e.c. A estela foi feita de basalto que não é material presente na natureza nas redondezas de Ashdod. Por isso, parece que foi preparada antes mesmo da guerra, partindo de uma certeza de que a vitória estaria garantida. Bustanai, Oded. יהודה ואשור (Judá e Assíria), Open University, Tel Aviv, 1984, pp. 6-10.
} 
Capítulo 3: O reinado de Ezequias

3.1 Os anos de reinado

Há divergência entre os pesquisadores ${ }^{136}$ a respeito da data em que Ezequias se tornou o rei de Judá.

Um método baseia-se em 2Rs 18:9-10, onde está escrito que a conquista de Israel ocorreu no $6^{0}$ ano do reinado de Ezequias. ${ }^{137}$ De acordo com os anais assírios, a conquista do Reino de Israel aconteceu em 722 a.e.c. Assim, seus anos de reinado teriam sido 727 a 698 a.e.c. Entre os pesquisadores que defendem esse método podemos mencionar Tadmor, Bustenai e Kaplinsky. ${ }^{138}$

O outro método baseia-se em 2Rs $18: 13$ e Is $36: 1$ onde está relatado que Senaquerib marchou para a região no $14^{\circ}$ ano de reinado de Ezequias. ${ }^{139}$ De acordo com os Anais de Senaquerib, sua Jornada ocorreu em 701 a.e.c. Assim, os anos de

136 Neeman, Nadav. עלייתה של ירושלים למעמד "העיר הראשה" בממלכת יהודה במאות הח'-הז' לפני סה" Ascensão de Jerusalém para a Posição da Cidade Principal no Reino de Judá nos Séculos 8 e 7 a.e.c.), Tzion 71, Historical Society of Israel, Jerusalém, 2006, pp. 410-427; Bustenai, Oded. הודה ואשור (Judá e Assíria), Open University, Tel Aviv, 1984, pp. 1-63; Kaplinski, Baruch. Hezekiah the Fourteenth King of the Davidic Dynasty and his Period (em hebraico), Israel Society for Biblical Research, Tel Aviv, 1990, pp. 23-24; Tadmor, Hayim. Verbete: "Cronologia”, in: Enciclopédia Bíblica, vol. 4, The Bialik Institute, Jerusalém, 1962, pp. 251-262.

137 2Rs 18:9-10: "No quarto ano de Ezequias, correspondente ao sétimo ano de Oséias, filho de Ela, rei de Israel, Shalmanesser, rei da Assíria, atacou a Samaria e a sitiou. No fim de três anos, conquistou-a. Foi no sexto ano de Ezequias, correspondente ao nono ano de Oséias, rei de Israel, que a Samaria foi tomada." Bíblia de Jerusalém, 2006, p. 532.

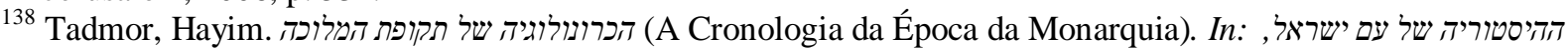
ימי המלוכה - היסטוריה מדינית (A História do Povo de Israel, o Período da Monarquia - História Política), Am Oved, Jerusalém, 1982, pp.50; -------------, ימי הבית הראשון ושיבת ציון (O Período do Primeiro Templo e o Retorno à Sião). In: History of the Jewish People, The Ancient Times. Ed.: Ben Sasson, Hayim Hilel. Devir. Tel Aviv, 1969, pp.138-145; ------------. Verbete: “Cronologia”, In: Enciclopédia Bíblica, vol. 4, The Bialik Institute, Jerusalém, 1962, pp. 251-262; Bustenai, Oded. יהודה ואשור (Judá e Assíria), Open University, Tel Aviv, 1984, pp. 1-63; Kaplinski, Baruch. Hezekiah the Fourteenth King of the Davidic Dynasty and his Period (em hebraico), Israel Society for Biblical Research, Tel Aviv, 1990, pp. 23-24.

139 2Rs 18:13: "No décimo quarto ano do rei Ezequias, Senaquerib, rei da Assíria, subiu contra todas as cidades fortificadas de Judá e apoderou-se delas." Bíblia de Jerusalém, 2006, pp. 532-533; Is 36:1: "No décimo quarto ano do rei Ezequias, subiu Senaquerib, rei da Assíria, contra todas as cidades fortificadas de Judá e as ocupou." Bíblia de Jerusalém, 2006, p. 1307. 
reinado de Ezequias teriam sido de 715 a 686 a.e.c. Entre os pesquisadores que defendem esse método podemos mencionar Neeman e Bright. ${ }^{140}$

De acordo com o primeiro método, Ezequias teria sido vassalo de Assíria durante a maior parte do seu reinado, rebelando-se somente no final dos seus dias, vindo a falecer logo após a Jornada de Senaquerib. Portanto, ele teria reinado por 22 anos antes da revolta, durante os quais teria agido para fortalecer e desenvolver o reinado.

De acordo com o segundo método, Ezequias teria iniciado a rebelião contra Assíria após dez anos de reinado e a Jornada de Senaquerib teria ocorrido nos meados do seu reinado. Assim, na segunda metade do seu reinado teria tentado reerguer-se das ruínas.

Tadmor, ${ }^{141}$ seguindo o primeiro método, descreve o início do reinado de Ezequias como muito tranqüilo devido ao fato de não ter participado de nenhuma revolta contra a Assíria antes da queda de Israel.

Nesses anos, Ezequias teve a oportunidade de estabelecer um reinado próspero, tanto política como economicamente. O aumento de riquezas, habitantes e do território foi fruto dessa estabilidade. Desta forma, mesmo pagando impostos para a Assíria, Judá se tornou um reino forte e muito importante no Oriente Próximo Antigo, na divisa entre o Egito e o Império Assírio. ${ }^{142}$

\footnotetext{
${ }^{140}$ Neeman, Nadav. עלייתה של ירושלים למעמד "העיר הראשה" בממלכת יהודה במאות הת'-הז' לפני סה"נ (A Ascensão de Jerusalém para a Posição da Cidade Principal no Reino de Judá nos Séculos 8 e 7 a.e.c.), Tzion 71, Historical Society of Israel, Jerusalém, 2006, pp. 410-427; Bright, John. História de Israel, $7^{\text {a }}$ edição, Paulus, São Paulo, 2003, pp. 338-349.

${ }^{141}$ Tadmor, Hayim. ימי הבית הראשון ושיבת ציון (O Período do Primeiro Templo e o Retorno a Sião). In: History of the Jewish People, The Ancient Times. Ed.: Ben Sasson, Hayim Hilel. Devir, Tel Aviv, 1969, pp. 138-141. Neste trabalho seguiremos esta opção.

${ }^{142}$ Idem.
} 


\subsection{Suas riquezas}

O relato bíblico apresenta o rei como dono de inúmeras riquezas:

"Ezequias possuiu muita riqueza e glória. Acumulou tesouros para si em ouro, prata, pedras preciosas, ungüentos, escudos e toda espécie de objetos preciosos. Teve armazéns para as safras de trigo, vinho e óleo; estábulos para as diferentes espécies de gado e apriscos para os rebanhos. Construiu cidades e um arrendamento abundante de gado graúdo e miúdo.,143

Os anais de Senaquerib descrevem a quantidade enorme de tributos que Ezequias mandou para o rei:

"He, Hezekiah,... and he sent me after my departure to Nineveh, my royal city, his elite troops (and) his best soldiers, which he had brought in as reinforcements to strengthen Jerusalem, with 30 talents of gold, 800 talents of silver, choice antimony, large blocks of carnelian, beds (inlaid) with ivory, armchairs (inlaid) with ivory, elephant hides, ivory, ebony-wood, boxwood, multicolored garments, garments of linen, wool (dyed) redpurple and blue-purple, vessels of copper, iron, bronze and tin, chariots...,144

Como Ezequias conseguiu todas essas riquezas?

O Reino de Judá localizava-se próximo a 2 dos principais caminhos de comércio: "O Caminho Principal", que ia da Arábia até Damasco, e "O Caminho do Mar", que ia do Egito até Damasco e Ásia Menor. Além disso, seus portos serviram como ponto de parada, aos comerciantes que navegavam pelo Mar Mediterrâneo e em volta da Península Arábica.

As caravanas eram obrigadas a passar pelos caminhos citados. Assim, cada uma que chegava, ou passava pelo território, pagava impostos no valor de $20-25 \%$

\footnotetext{
${ }^{143} 2$ Cr 32:27-29. Bíblia de Jerusalém, 2006, p. 621.

144 Tradução das linhas 37-45, coluna 3, no "Prisma de Senaquerib", feita por Holladay, John S. Jr. Hezekiah's Tribute, Long-Distance Trade, and the Wealth of Nation ca. 1000-600 BC: A New Perspective. In: Confronting the Past: Archaeological and Historical Essays on Ancient Israel in Honor of William G. Dever. Ed.: Seymour Gitin, J. Edward Wright, J.P Dessel, Eisenbrauns, EUA, 2006, p. 312.
} 
das mercadorias ao rei de Judá. Dessa forma, ele obteve produtos que provinham de outras regiões, como por exemplo: ouro, prata, marfim, especiarias, madeiras raras, pedras preciosas e os mais variados tecidos e perfumes. Ezequias certamente também poderia comprar mercadorias. ${ }^{145}$

O rei desenvolveu a agricultura, ${ }^{146}$ obtendo, assim, produtos agrícolas tais como óleo, trigo, frutas secas etc., que poderiam servir como moeda de troca na aquisição de mercadorias que não havia em Judá. Outros produtos do reino foram as madeiras locais, como o pinheiro, o asfalto extraído do Mar Morto etc. ${ }^{147}$

As riquezas de Ezequias ${ }^{148}$ eram provenientes, também, das guerras contra os filisteus $^{149}$ - das quais ele obteve os despojos de guerra -, doações, presentes e tributos:

"Ezequias ordenou que se preparassem celeiros no Templo de lahweh, o que foi feito. Depositaram-se ali, fielmente, as oferendas, os dízimos e as coisas consagradas." 150 (2Cr 31:11-12)

"Muitos levaram a Jerusalém uma oblação para lahweh e presentes para Ezequias, rei de Judá, que, depois desses acontecimentos, adquiriu prestígio aos olhos de todas as nações." ${ }^{151}$ (2Cr 32:23)

No Templo, eram guardadas todas as contribuições trazidas pelos peregrinos e, no palácio, eram depositados todos os presentes, as doações e os tributos feitos

\footnotetext{
${ }^{145}$ Har-El, Menashe. The Ancient Landscapes of the Land of Israel (em hebraico), Kineret, Zmora-Bitan, Dvir, Or Yehuda, 2005, pp. 9-12, 408-428; Holladay, John S. Jr. Hezekiah's Tribute, Long-Distance Trade, and the Wealth of Nation ca. 1000-600 BC: A New Perspective. In: Confronting the Past: Archaeological and Historical Essays on Ancient Israel in Honor of William G. Dever. Ed.: Seymour Gitin, J. Edward Wright, J.P Dessel, Eisenbrauns, EUA, 2006, pp. 309-331.

${ }^{146} 2 \mathrm{Cr} 32: 28-29$.

${ }^{147}$ Vide nota 145

${ }^{148}$ Kaplinski, Baruch. Hezekiah the Fourteenth King of the Davidic Dynasty and his Period (em hebraico), Israel Society for Biblical Research, Tel Aviv, 1990, pp. 187-194.

${ }^{149}$ 2Rs 18:8.

${ }^{150}$ Bíblia de Jerusalém, 2006, p. 619.

${ }^{151}$ Idem, p. 621.
} 
diretamente ao rei. Em dias de necessidade, o rei usava as duas fontes de riquezas para pagar dívidas: ${ }^{152}$

"O rei da Assíria exigiu de Ezequias, rei de Judá, trezentos talentos de prata e trinta talentos de ouro, e Ezequias entregou toda a prata que achava no Templo de lahweh e nos tesouros do palácio real. ${ }^{, 153}$ (2Rs 18:14-15)

${ }^{152}$ Holladay, John S. Jr. Hezekiah's Tribute, Long-Distance Trade, and the Wealth of Nation ca. 1000-600 BC: A New Perspective. In: Confronting the Past: Archaeological and Historical Essays on Ancient Israel in Honor of William G. Dever. Ed.: Seymour Gitin, J. Edward Wright, J.P Dessel, Eisenbrauns, EUA, 2006, pp. 309-331.

153 Bíblia de Jerusalém, 2006, p. 533. 
Capítulo 4: As Guerras de Ezequias

\subsection{Ezequias e os filisteus}

Sobre a guerra de Ezequias contra os filisteus temos o relato em 2Rs 18:8:

"Derrotou os filisteus até Gaza, devastando seu território, desde as torres de vigia até as cidades fortificadas." 154

Ezequias não se contentou em devolver ao seu reino os territórios conquistados pelos filisteus nos dias de Acaz, seu pai, ${ }^{155}$ e aumentou as fronteiras do Reino de Judá para o oeste até Gaza. ${ }^{156}$

No trecho que descreve as ações do Ezequias, em 2Cr capítulos 29 a 32, não há um relato dessa batalha. No entanto, ela está descrita em outros dois documentos:

1. Em 1Cr 4:39-43, que se refere à tribo de Simeon e seu local de assentamento, o cronista relata uma ação militar dos dias de Ezequias:

"Percorreram desde o passo de Gedor até o oriente do vale, procurando pastagens para seu gado... Eram os camitas os que habitavam lá antes. Os simeonitas, inscritos por seus nomes, chegaram no tempo de Ezequias, rei de Judá... e se estabeleceram em seu lugar... Alguns deles, pertencentes aos filhos de Simeão, foram para a montanha de Seir... Abateram o resto dos sobreviventes de Amalec e fizeram lá a sua morada..."157

\footnotetext{
154 Idem, p. 532.

155 2Cr 28:16-18, "Por esse tempo, Acaz mandou pedir ao rei da Assíria que o socorresse... Os filisteus fizeram incursões contra as cidades da Planície e do Negueb de Judá... e aí se estabeleceram.” Bíblia de Jerusalém, 2006, p. 615.

${ }^{156}$ Tadmor, Hayim. Assyria, Babylonia and Judah (em hebraico). Ed.: Cogan Mordechai, The Bialik Institute, Jerusalém, 2006, p. 229-232.

${ }^{157}$ Bíblia de Jerusalém, 2003, p. 555.
} 
2. Nos anais de Senaquerib, que relatam a Jornada assíria para Israel em 701 a.e.c., está escrito:

"The officials, nobles, and people of Ekron who had thrown Padi their king bound by oath and curse of Assyria into fetters of iron and had given him over to Hezekiah, the Judahite - he kept him in confinement like an enemy their heart became afraid, and they called upon the Egyptian kings..."158

A extradição do rei de Ekron, Padi, para Ezequias, sem nomear outro rei em seu lugar, demonstra a grande influência que Ezequias tinha na cidade.

Como mencionado anteriormente, dois fatores provocaram mudanças no equilíbrio entre o Reino de Judá e a Filistéia, durante o reinado de Ezequias: as invasões assírias na Filistéia entre 734-720 a.e.c. e as revoltas internas nas cidades filistéias. $^{159}$

Ao contrário dessas, Judá se destaca pela união de suas forças em torno da autoridade central, fortalecendo-se e aumentando sua potência militar. ${ }^{160}$

\footnotetext{
${ }^{158}$ Luckenbill, Daniel David. The Annals of Sennacherib. Oriental Institute Publications 2. Chicago: Univ. of Chicago, 1924, pp. 27-31, coluna 2, linhas 73-78.

${ }^{159}$ Bustanai, Oded. יהודה ואשור' (Judá e Assíria), Open University, Tel Aviv, 1984, pp. 6-10.

${ }^{160}$ Tadmor, Hayim. Assyria, Babylonia and Judah (em hebraico). Ed.: Cogan Mordechai, The Bialik Institute, Jerusalém, 2006, p. 229-232.
} 
4.2 A revolta contra a Assíria

\subsubsection{A situação anterior à revolta}

"... e ele teve êxito em todos os seus empreendimentos. Revoltou-se contra o rei da Assíria e não mais the foi submisso."161 (2Rs 18:7)

A revolta de Ezequias contra Senaquerib teve algumas metas: ${ }^{162}$

1. Libertação do jugo da Assíria e renovação da independência de Judá.

2. Unificação territorial e política do extinto Reino de Israel com o Reino de Judá.

3. Alcance da hegemonia de Israel, atacando províncias assírias.

Com a ascensão de Senaquerib ao poder, em 705 a.e.c., foram criadas condições que incentivaram Ezequias a rebelar-se contra a Assíria, ${ }^{163}$ a saber:

1. A morte repentina de Saragon II no campo de batalha, em 705 a.e.c., trouxe inquietação para dentro da Assíria, situação entendida pelos povos dominados como enfraquecimento do império, gerando, assim, possibilidade de revolta.

2. A conquista assíria do litoral da Fenícia e de Israel, até o território dos filisteus, ${ }^{164}$ atingiu a economia do Egito ameaçando sua soberania. Por isso,

${ }^{161}$ Bíblia de Jerusalém, 2003, p. 532.

${ }^{162}$ Bustanai, Oded. יהודה ואשורי (Judá e Assíria), Open University, Tel Aviv, 1984, pp. 11-13.

יהודה ואשור ${ }^{163}$ Bright, John. História de Israel, 7a edição, Paulus, São Paulo, 2003, pp. 338-349; Bustanai, Oded (Judá e Assíria), Open University, Tel Aviv, 1984, pp. 11-13; Tadmor, Hayim. Assyria, Babylonia and Judah (em hebraico). Ed.: Cogan Mordechai, The Bialik Institute, Jerusalém, 2006, pp. 255-274.

${ }^{164}$ Luckenbill, Daniel David. The Annals of Sennacherib. Oriental Institute Publications 2. Chicago, Univ. of Chicago, 1924, pp. 27-31, coluna 2, linhas 60-72: "But Sidka, the king of Ashkelon, who had not submitted to my yoke, the gods of his father's house, himself, his wife, his sons, his daughters, his brothers, the seed of his paternal house, I tore away and brought to Assyria. Sharru-lu-dari, son of Rukibti, their former king, I set 
o faraó egípcio, Shabataka, incentivou Ezequias a rebelar-se contra a Assíria, prometendo-Ihe ajuda militar.

3. Merodac-Baladã, o príncipe caldeu que reinou na Babilônia e foi derrotado por Saragon II em 710 a.e.c., restabeleceu-se como rei após a morte desse último. Ele fez um pacto com Ezequias e juntos desafiaram os assírios.

4. Lulê, Rei de Tiro seguiu uma política anti-assíria. Ele compactuou com Ezequias, incentivando-o a rebelar-se contra a Assíria.

5. A forte posição de Ezequias em Ekron e o pacto com o governante de Ashkelon aumentaram as chances de sucesso dessa revolta e a possibilidade de bloquear o exército assírio em sua marcha para conquistar o Reino de Judá.

A revolta de Ezequias contra Senaquerib, em 701 a.e.c., foi resultado de sua política de expansão. Por um lado, abordou reis que foram leais ao rei assírio, e, por outro, desmantelou a ordem estabelecida por esse rei na região. ${ }^{165}$ accepted my yoke. In the course of my campaign, Beth-Dagon, Joppa, Banaibarka, Asuru, cities of Sidka, who had not speedily bowed in submission at my feet, I besieged, I conquered, I carried off their spoil."

165 Bustanai, Oded. בין חזקיהו לערי פלשת (Entre Ezequias e as Cidades Filistéias), Sefer Barslavi, Israel Society for Biblical Research, Jerusalém, 1970, pp. 79-88. 
4.2.2 Os preparativos de Ezequias

De acordo com o relato bíblico, Ezequias preparou-se para a revolta em algumas frentes: ${ }^{166}$

1. Reorganizou a administração de Judá ${ }^{67}$ e construiu cidades-celeiros para armazenar alimentos; ${ }^{168}$

2. Organizou o exército ${ }^{169}$ e fez pactos com seus vizinhos; ${ }^{170}$

3. Fortaleceu Jerusalém e outras cidades no reino; ${ }^{171}$

4. Trouxe água para dentro de Jerusalém. ${ }^{172}$

\footnotetext{
${ }^{166}$ Bustanai Oded, יהודה ואשור (Judá e Assíria), Open University, Tel Aviv, 1984, pp. 64-65.

${ }^{167}$ Is $22: 15-25 ; 2$ Rs $18: 18$.

$1682 \mathrm{Cr} 32: 28$.

${ }^{169} 2 \mathrm{Cr} 32: 6-8$.

${ }^{170}$ Is $30: 1-7,31: 1-3$.

171 2Cr 32:1-5; Is 22:10, 36:1-2; 2Rs 18:13.

172 2Rs 20:20; 2Cr 32:1-4, 30; Is 22:9-11.
} 
4.2.2.1 Reorganização da administração de Judá

No estrato III das ruínas de Laquis, foram achadas 320 asas de jarros com a inscrição: "למלך" (Im/k) "Pertencente ao rei"; abaixo da inscrição, um desenho de besouro com 4 ou 2 asas e, abaixo dele, o nome de uma de 4 cidades: ${ }^{173}$ Hebron, Zif, Soco e mmst (temos somente as consoantes do nome dessa cidade, pois não se conhece ao certo sua localização e não se sabe como seu nome era pronunciado.)

As primeiras duas estão situadas nas colinas de Hebron; Soco estava provavelmente na Sefelá (a planície costeira) e mmst é desconhecida. Pode ter sido um título de Jerusalém (redução de mmslt 'governo'). ${ }^{174}$

De acordo com Aharoni, ${ }^{175}$ esses vasos foram feitos por ordem de Ezequias, como preparação administrativa dentro do Reino de Judá, pouco antes da Jornada de Senaquerib.

Aharoni sugere que os jarros foram destinados ao pagamento organizado de imposto real e que os nomes que aparecem em cada jarro representam os centros administrativos responsáveis pelo recolhimento desses impostos, ערי מסכנות, as chamadas "cidades celeiros."

Esses centros administrativos foram uma renovação de Ezequias. Antes de seu reinado, havia 12 centros regionais, que ele reduziu a 4 e, ao centralizá-los, melhorou a forma de recolher os impostos. As cidades escolhidas não foram as

\footnotetext{
${ }^{173}$ Vide anexo 6.

${ }^{174}$ Mazar, Amihai. Arqueologia na terra da Bíblia - 10.000 - 586 a.C., Paulinas, São Paulo, 2003, pp. 408-436; Avigad, Nahman. Excavations in the Jewish Quarter of the Old City, 1969-1971. In: Jerusalem RevealedArchaeology in the Holy City 1968-1974, The Israel Exploration Society, Jerusalém, 1975, pp. 41-54.

175 Aharoni, Yohanan. The Land of Israel in Biblical Times a Historical Geography (em hebraico), The Bialik Institute, Jerusalém, 1962, pp. 312-323.
} 
principais, mas cada uma delas já havia sido fortificada e ficava no caminho principal para Jerusalém.

A melhoria no recolhimento de impostos auxiliou Ezequias nos preparativos da revolta contra a Assíria. Assim, ele obteve um controle maior das provisões que serviriam o exército, bem como a concentração dos bens do reinado.

Outra ação administrativa de Ezequias pode ser observada na troca de funcionários de alto escalão dentro do palácio. ${ }^{176}$ Em Isaías 22:15, Sobna tem a função mais importante no palácio, a de "אשר על הבית" "Intendente do palácio."177 Mas, alguns versículos adiante, 21-24, Eliacim, filho de Helcias, recebe a sua função e suas vestimentas. Em 2Rs 18:18, e 18:37, Eliacim aparece com o titulo "chefe do palácio"178 e Sobna com o de secretário.

É possível que o túmulo de Sobna tenha sido encontrado numa das necrópoles de Jerusalém, em Siloé, na encosta ocidental do vale Cedron, em frente à "Cidade de Davi." Nesse lugar foram descobertas tumbas elaboradas, escavadas nos penhascos, que pertenciam a importantes personalidades de Jerusalém. ${ }^{179}$

Num dos túmulos, foi achada uma inscrição de $21 \times 132 \mathrm{~cm}$, com três linhas escritas em hebraico, em $1870 .{ }^{180}$ Pesquisas paleográficas revelaram que ela foi gravada em 700 a.e.c. aproximadamente e que, pela semelhança das letras e da

\footnotetext{
${ }^{176}$ Bustenai, Oded. יהודה ואשור (Judá e Assíria), Open University, Tel Aviv, 1984, pp. 15-17; Vainstub, Daniel. Hebrew Inscriptions of the First Temple Period (em hebraico). In: The History of Jerusalem. Ed.: Shmuel Ahituv e Amihai Mazar, Yad Ben Zvi, Jerusalém, 2000, pp. 275-277.

${ }^{177}$ Bíblia de Jerusalém, 2006, pp. 1286-1287.

${ }^{178}$ Idem, p. 533.

${ }^{179}$ Sass, Benjamin. Script and Inscriptions in the Biblical Period (em hebraico), Open University, Tel Aviv, 1992, pp. 39-40; Ahituv, Shmuel. כתובות עבריות מירושלים של ימי בית ראשון (Inscrições Hebraicas de Jerusalém no Período do Primeiro Templo). In: ירושלים בימי בית ראשון (Jerusalém no Período do Primeiro Templo.) Ed.: Naor Mordechai, Yad Ben Zvi, Jerusalém, 1990, pp. 90-101.

${ }^{180}$ Vide anexo 7.
} 
forma, pertence à mesma época da Inscrição de Siloé e à época de Ezequias e Isaías. ${ }^{181}$

A inscrição apresenta uma função administrativa muito importante no palácio real "אשר על הבית", que já mencionamos. O respeitável homem ali enterrado era funcionário de alto escalão dentro do palácio - uma espécie de primeiro ministro. Junto a ele foi enterrada sua 'serva'. Pode ser que a expressão 'serva' refira-se à sua amada mulher. ${ }^{183}$

É difícil determinar quem é o funcionário enterrado naquele local. Alguns

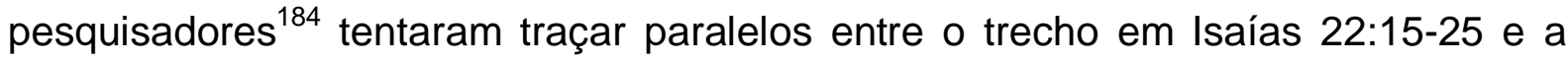
inscrição, alegando que ela se refere a Sobna, que foi amaldiçoado por Isaías por construir uma tumba parecida com os túmulos dos fenícios. Mas também pode pertencer a outra pessoa, que em outro momento ostentava esse título no palácio. Como por exemplo, Eliacim, filho de Helcias, que ocupou o lugar de Sobna após sua deposição, conforme 2Rs 18:18.

Apesar da dificuldade de definir quem seria a personalidade enterrada naquele local, não podemos ignorar a semelhança entre a descrição em Isaías e a localização desse túmulo majestoso, no topo da colina, em frente à "Cidade de Davi." Daí a suposição de que a escrita na tumba foi gravada com a ordem de Sobna. ${ }^{185}$

\footnotetext{
${ }^{181}$ Vide nota 179.

${ }^{182}$ De Vaux, Ronald. חיי יום יום בישראל בימי המקרא (A Vida Cotidiana em Israel na Época da Bíblia), Volume 1, Ed.: Massada e Am Hassefer, Tel Aviv 1969, pp. 141-143.

${ }^{183}$ Vide nota 179.

${ }^{184}$ Bustenai, Oded. יהודה ואשור (Judá e Assíria), Open University, Tel Aviv, 1984, pp. 15-17; Ahituv, Shmuel. כתובות עבריות מירושלים של ימי בית ראשון (Inscrições Hebraicas de Jerusalém no Período do Primeiro Templo). In: ירושלים בימי בית ראשון (Jerusalém no Período do Primeiro Templo). Ed.: Naor Mordechai, Yad Ben Zvi, Jerusalém, 1990, pp. 90-101.

${ }^{185}$ Vide nota 179.
} 


\subsubsection{Organização do exército e pactos com povos vizinhos}

Em $2 \mathrm{Cr}$ 32:5-8 o cronista descreve Ezequias preparando muitas armas e escudos e montando um exército de voluntários para lutar contra a Assíria:

"... mandou fazer armas e escudos em abundância. Colocou generais à frente do povo, reuniu-os ao seu redor na praça da porta da cidade e os encorajou... não temais, nem vos apavoreis diante do rei da Assíria..."

Os anais de Senaquerib também mencionam o exército regular e o de voluntários de Ezequias: ${ }^{187}$

"... and the Urbi and his mercenary troops which he had brought in to strengthen Jerusalem, his royal city... "188

Segundo esses anais, o rei preparou um forte exército, composto de soldados arameus, trazidos para defender Jerusalém do ataque assírio.

Tadmor $^{189}$ defende que os urbi, que aparecem nesses anais, fazem parte do exército de voluntários formado por Ezequias.

Outra etapa dos preparativos pode ser deduzida a partir da abundância de jarros com a inscrição "למלך" Imlk ("Pertencente ao rei”), que foi encontrada em várias escavações em Israel e aponta, como mencionado no item anterior, que o rei de Judá estava preparando provisões para o seu vasto exército. ${ }^{190}$

Ezequias juntou-se ao rei Lulê, de Tiro; ao rei Sidka, de Askelon; aos nobres de Ekron. O Faraó Shabataka prometeu apoiar os rebeldes, na revolta contra a

\footnotetext{
${ }^{186}$ Bíblia de Jerusalém, 2006, p. 620.

${ }^{187}$ Mazar, Binyamin. Sennacherib's Judean Campaign (em hebraico). In: The Military History of the Land of Israel in Biblical Times. Ed.: Jacob Liver, Maarachot, Tel Aviv, 4 a edição, 1968, pp. 286-295.

${ }^{188}$ Luckenbill, Daniel David. The Annals of Sennacherib. Oriental Institute Publications 2. Chicago: Univ. of Chicago, 1924, pp. 31-36, coluna 3, linhas 37-40.

189 Tadmor, Hayim. Assyria, Babylonia and Judah (em hebraico). Ed.: Cogan Mordechai, The Bialik Institute, Jerusalém, 2007, pp. 275-282.

${ }^{190}$ Idem.
} 
Assíria. ${ }^{191}$ O "Prisma de Senaquerib" relata o castigo de cada um desses reis após o fracasso da revolta: ${ }^{192}$

"Lulê, king of Sidon... and far off into the midst of the sea he fled. There he died... But Sidka, the king of Ashkelon... the gods of his father's house, himself, his wife, his sons, his daughters, his brothers, the seed of his paternal house, I tore away and brought to Assyria... The Egyptian charioteers and princes, together with the Ethiopian king's charioteers, my hands captured alive in the midst of the battle... I approached Ekron and slew the governors and nobles who had rebelled, and hung their bodies on stakes around the city. The inhabitants who rebelled and treated (Assyria) lightly I counted as spoil."

${ }^{192}$ Luckenbill, Daniel David. The Annals of Sennacherib. Oriental Institute Publications 2. Chicago: Univ. of Chicago, 1924, pp. 27-36, coluna 2, linhas 38-83, e coluna 3, linhas 1-11. 
4.2.2.3 O fortalecimento de Jerusalém e de outras cidades no reino

Em Is 22:10, temos: “...as casas de Jerusalém, demolistes as casas para reforçar a muralha."193 Em 2Cr 32:5, o cronista relata: "Para se fortificar, Ezequias consertou todas as brechas da muralha, sobre ela construiu torres, ergueu uma segunda muralha na parte externa..."

As escavações no bairro judeu da cidade velha de Jerusalém demonstram que, durante os séculos 8 e 7 a.e.c., uma sólida e grossa muralha ${ }^{195}$ foi construída na encosta oriental da colina ocidental de Jerusalém. Um dos segmentos dessa muralha de pedra tem a espessura de 7 metros. A grossura e a solidez da muralha foram projetadas para defender os bairros habitados dessa colina e resistir aos ataques assírios. Para a sua construção, casas mais antigas foram demolidas e o material usado para reforçar a muralha. ${ }^{196}$

No topo da colina, ao norte da maciça muralha, foram encontrados os remanescentes de uma grande torre e de uma muralha com 8 metros de altura. ${ }^{197}$

Outra cidade, fortemente fortificada por Ezequias, é a cidade de Laquis. O estrato III nas escavações de Laquis ${ }^{198}$ revela que, no final do século 8 a.e.c.,

\footnotetext{
${ }^{193}$ Bíblia de Jerusalém, 2006, p. 1286.

${ }^{194}$ Idem, p. 620.

195 Vide anexo 8.

${ }^{196}$ Avigad Nahman. Excavations in the Jewish Quarter of the Old City, 1969-1971. In: Jerusalem RevealedArchaeology in the Holy City 1968-1974, The Israel Exploration Society, Jerusalém, 1975, pp. 41-51; Mazar, Amihai. Arqueologia na terra da Bíblia - 10.000 - 586 a.C., Paulinas, São Paulo, 2003, pp. 398-408; Finkelstein, Israel e Silberman, Niel Asher. The Bible Unearthed Archaeology's New Vision of Ancient Israel and the Origin of its Sacred Texts (em hebraico), Tel Aviv University, Tel Aviv, 2003, pp. 248-261.

${ }^{197}$ Mazar, Amihai. Arqueologia na terra da Bíblia - 10.000 - 586 a.C., Paulinas, São Paulo, 2003, pp. 398-408; Mazar, Binyamin. Jerusalem in the Biblical Period. In: Jerusalem Revealed - Archaeology in the Holy City 1968-1974, The Israel Exploration Society, Jerusalém, 1975, pp. 1-8.

${ }^{198}$ Barkai, Gabriel. The Archaeology of Ancient Israel in the Biblical Period - The Iron Age II. Open University, Tel Aviv, 1990, pp.122-131; Mazar, Amihai. Arqueologia na terra da Bíblia - 10.000 - 586 a.C., Paulinas, São Paulo, 2003, pp. 398-408; Finkelstein, Israel; Silberman, Niel Asher. The Bible Unearthed Archaeology's New Vision of Ancient Israel and the Origin of its Sacred Texts (em hebraico), Tel Aviv University, Tel Aviv, 2003, pp. 248-261.
} 
Laquis era a segunda cidade mais importante de Judá. Ela está localizada na planície costeira perto da estrada principal que levava ao "Caminho do Mar." Ezequias a fortificou com uma muralha externa de pedras e uma outra interna, cujo topo foi construído com tijolos de barro, assentados sobre uma fundação de pedras com 6 metros de espessura.

Uma torre gigante defendia o portão de 6 câmaras que levava à cidade. Dentro da cidade foi erguido um altar - provavelmente onde estava localizado o palácio do governador da cidade - e, ao lado desse, foram construídos estábulos. ${ }^{199}$

É provável que algumas partes dessas fortificações tenham sido erguidas antes do reinado de Ezequias, mas durante o seu reinado, a cidade foi mantida em ótimas condições, pronta para o confronto com Senaquerib. ${ }^{200}$ 


\subsubsection{O projeto de abastecimento de água para Jerusalém}

A nascente de Gihon gerou um problema duplo para Ezequias: impedir que o exército assírio usufruísse da água e assegurar o fornecimento de água para a cidade, em caso de cerco.

Para que os inimigos de Judá não usassem a água da nascente, o rei bloqueou sua saída, direcionando o curso da água para dentro de Jerusalém. ${ }^{201}$

Em caso de cerco longo a Jerusalém, o maior problema que seus habitantes teriam que enfrentar seria a falta d'água. Jerusalém está localizada no topo da montanha e não possuiu abastecimento regular de água dentro do perímetro murado da cidade. Para obter água, os moradores da cidade saíam das muralhas protetoras e desciam até a nascente de Gihon.

Uma das maiores realizações de Ezequias, citada no relato bíblico, ${ }^{202}$ foi o túnel escavado dentro da montanha de Jerusalém, o monte Sião, para levar a água de Gihon até um reservatório, denominado "Piscina (Reservatório) de Siloé"203 que ficava dentro das muralhas da cidade..$^{204}$

${ }^{201} 2 \mathrm{Cr}$ 32:2-4-30: "Vendo, então, Ezequias que Senaquerib chegava com intenção de atacar Jerusalém, decidiu, com seus oficiais e seus guerreiros, obstruir as águas das nascentes que estavam fora da cidade e eles the prestaram ajuda. E tendo-se reunido uma grande multidão, obstruíram todas as fontes e o riacho que corria pelo território, dizendo: 'Por que os reis da Assíria, vindo aqui, haveriam de achar água em abundância?' ... Foi Ezequias que obstruiu a saída superior das águas do Gihon e as canalizou para baixo, para o ocidente da cidade de Davi." Bíblia de Jerusalém, 2006, pp. 620, 621. Ver também Eclesiástico 48:17: "Ezequias fortificou a sua cidade e conduziu a água para o seu centro. Com ferro cavou a rocha e construiu cisternas." Bíblia de Jerusalém, 2006, p. 1222.

202 2Rs 20:20: "O resto da história de Ezequias, todas as suas façanhas, e como construiu o reservatório e o aqueduto para levar água à cidade...” Bíblia de Jerusalém, 2006, p. 537.

${ }^{203}$ 2Rs 20:20, Bíblia de Jerusalém, 2006, p. 537,538 - nota de rodapé i: "A fonte de Gihon ficava fora da cidade. Ezequias mandou cavar na rocha um túnel para de lá conduzir a água à piscina chamada de Siloé, o 'reservatório' de Is 22,11 e Eclo 48,17, no interior das muralhas. Este canal substituía outro, mais antigo, cavado em parte a céu aberto no lado oriental do monte Sião, e que levava as águas a outra piscina, situada um pouco mais abaixo que a piscina de Siloé."

${ }^{204}$ Bustenai Oded. יהודה ואשור (Judá e Assíria), Open University, Tel Aviv, 1984, pp. 13-16; Ussishkin, David. מפעלי המים של ירושלים בימי חזקיהו (Os Projetos de Suprimento de Água em Jerusalém nos Dias de Ezequias), Katedra 70, Yad Ben Zvi, Jerusalém, 1994, pp.3-28; Rubin, Rehav. Jerusalem and its Environs: the Impact of 
O túnel foi descoberto por Eduard Robinson Smith, em 1838. Entre 1909-1911 a comissão Parker limpou o túnel do acúmulo de terra e Vincent Louis Hugues realizou medições e descobriu que o comprimento do túnel curvado é de $533,10 \mathrm{~m}$. A sua largura média é de $0,60 \mathrm{~cm}$ e a sua altura varia de $1,5 \mathrm{~m}$ a $5,0 \mathrm{~m}$, com altura média de $1,80 \mathrm{~m}$.

A pesquisa de Vincent foi publicada em Underground Jerusalem: Discoveries on the Hill of Ophel (1909-1911), por H. Cox, Londres, 1911. Sua avaliação é a mais completa feita até hoje e é aceita pelos pesquisadores. ${ }^{205}$

De acordo com Yigal Shiloh, ${ }^{206}$ a diferença entre o inicio do túnel, no ponto mais alto e o seu final, no ponto mais baixo é de $0,30 \mathrm{~cm}$, o que significa uma inclinação média de apenas $0,06 \%$ ao longo de todo o seu percurso.

A escavação foi realizada por dois grupos de operários que partiram de extremidades opostas, escavando até que se encontrassem. $O$ momento do encontro dos dois grupos foi registrado numa inscrição de $60 \times 50 \mathrm{~cm}$, datada do final do século 7 a.e.c., que recebeu o nome "A Inscrição de Siloé"207 e foi entalhada na parede do túnel, perto de sua saída. ${ }^{208}$

A longa inscrição em hebraico apresenta de forma dramática, numa linguagem literária, o momento de encontro dos dois grupos de escavadores. Seu formato, que

Geographical and Physical Conditions on the Development of Jerusalem (em hebraico). In: The History of Jerusalem. Ed.: Ahituv Shmuel e Mazar Amihai, Yad Ben-Zvi, Jerusalém, 2000, pp.1-12

205 Mazar, Amihai. Jerusalem's Water Supply in the First Temple Period (em hebraico). In: The History of Jerusalem, the Biblical Period. Ed.: Shmuel Ahituv e Amihai Mazar, Yad Ben-Zvi, Jerusalém, 2000, pp. 195132; Ussishkin, David. מפעלי המים של ירושלים בימי חזקיהו (Os Projetos de Suprimento de Água em Jerusalém nos Dias de Ezequias), Katedra 70, Yad Ben Zvi, Jerusalém, 1994, pp. 3-28.

${ }^{206}$ In: Mazar, Amihai. Jerusalem's Water Supply in the First Temple Period (em hebraico). In: The History of Jerusalem, the Biblical Period. Ed.: Shmuel Ahituv e Amihai Mazar, Yad Ben-Zvi, Jerusalém, 2000, pp. 217218.

207 Vide anexo 9.

208 Amiran, Ruth. The Water Supply of Israelite Jerusalem. In: Jerusalem Revealed - Archaeology in the Holy City 1968-1974, The Israel Exploration Society, Jerusalém, 1975, pp. 75-78; Mazar, Amihai. Jerusalem's Water Supply in the First Temple Period (em hebraico). In: The History of Jerusalem, the Biblical Period. Ed.: Shmuel Ahituv e Amihai Mazar, Yad Ben-Zvi, Jerusalém, 2000, pp. 218-221. 
é o mais longo e complexo de todas as inscrições da época do 1ำ Templo descobertas até hoje, mostra a importância do acontecimento para os habitantes de Jerusalém, e a extraordinária conquista dos realizadores da escavação. ${ }^{209}$

O túnel de Ezequias é considerado o mais audacioso projeto hidrotécnico de Israel em sua época. Além de sua importância militar, demonstra um planejamento metropolitano muito desenvolvido. O projeto permitiu a condução de toda a água da fonte de Gihon, através de um túnel subterrâneo, até um reservatório que ficava dentro das muralhas de Jerusalém. Assim, Ezequias obteve o controle absoluto sobre o uso da água. ${ }^{210}$ 
Capítulo 5: A Jornada de Senaquerib

5.1 O relato da Jornada

A Guerra de Senaquerib contra Judá e a "salvação" de Jerusalém, são longamente detalhadas no relato bíblico. Essa narração é a mais extensa de todas as descrições dos confrontos entre o povo de Israel e a Assíria.

Nas fontes assírias há também informações muito detalhadas a esse respeito. Os anais de Senaquerib da sua "Terceira Incursão Militar" possuem o relato mais minucioso de todas as campanhas militares dos reis assírios conhecidos até hoje. ${ }^{211}$

Estes expõem o sucesso do rei na guerra contra a Fenícia e a Filistéia, o castigo imposto ao rebelde Reino de Judá, a rendição de Ezequias e o detalhamento dos inúmeros tributos enviados a Nínive.

Em tudo que diz respeito ao tributo em ouro e prata enviado por Ezequias à Assíria, há uma semelhança espantosa entre a fonte bíblica e a assíria. As duas mencionam a quantidade de trinta talentos de ouro. Em relação à prata, a fonte assíria descreve a chegada de oitocentos talentos de prata, enquanto a bíblica menciona o envio de apenas trezentos. Mas deve-se acrescentar a esses a prata retirada dos portões do Templo e enviada à Assíria. ${ }^{212}$

$\mathrm{Na}$ descrição do final do confronto, há uma diferença entre as duas fontes. A bíblica mostra a derrota milagrosa de Senaquerib, enquanto a assíria relata a derrota

\footnotetext{
${ }^{211}$ Tadmor Hayim. Assyria, Babylonia and Judah (em hebraico). Ed.: Cogan Mordechai, The Bialik Institute, Jerusalém, 2007, pp. 255-274.

${ }^{212}$ Idem.
} 
de Ezequias. Essa contradição entre as duas fontes suscitou algumas hipóteses. Uma delas cogita de duas Jornadas de Senaquerib para Judá. ${ }^{213}$

Bright $^{214}$ alega que essa discussão não pode ser resolvida, por falta de evidências. Ainda assim, assume a possibilidade de duas campanhas, uma em 701 a.e.c. e, a outra, alguns anos mais tarde. Bright baseia sua suposição numa divisão do relato bíblico, argumentando que 2Rs $18: 14-16$ e os anais de Senaquerib, descrevem acontecimentos que ocorreram em 701 a.e.c., enquanto todos os outros trechos sobre o assunto em Reis, relatam uma outra campanha dos assírios.

$\operatorname{Mazar}^{215}$ não aceita a possibilidade de duas campanhas, alegando que não há nenhum suporte a esse respeito nos documentos assírios.

Grabbe ${ }^{216}$ em seu livro Like a Bird in a Cage, the Invasion of Sennacherib in 701 ECE, traz o histórico das opiniões dos pesquisadores, além dos mencionados acima, a respeito do assunto:

1. Alguns dos pesquisadores que acreditaram na realização de duas campanhas assírias:

George Rawlinson, ${ }^{217}$ em 1864, defendeu que, de acordo com o relato bíblico, é possível perceber que a principal meta da Assíria foi conquistar o Egito e por isso foram realizadas duas campanhas em direção a Israel;

Dougherty Raymond Philip ${ }^{218}$ aceitou a opinião de duas campanhas, apesar de não oferecer nenhuma justificativa para essa opinião.

\footnotetext{
${ }^{213}$ Idem.

${ }^{214}$ Bright, John. História de Israel, $7^{\text {a }}$ edição, Paulus, São Paulo, 2003, pp. 360-373.

215 Mazar, Binyamin Sennacherib's Judean Campaign (em hebraico). In: The Military History of the Land of Israel in Biblical Times. Ed.: Jacob Liver, Maarachot, Tel Aviv, $4^{\text {a }}$ edição, 1968, pp. 286-296.

${ }^{216}$ Grabbe, Lester L. Like a bird in a cage, the Invasion of Sennacherib in 701 ECE. Ed.: Grabbe Lester. L., T\&T Clark International, Londres, 2003 pp. 2-36.

${ }^{217}$ In: Grabbe, p. 21: Rawlinson, George. The Five Great Monarchies of the Ancient Eastern World: the Second Monarch Assyria, 4 volumes, Londres, John Murray, 1864, pp. 430-446.
} 
Albright $^{219}$ alegou que foram realizadas duas campanhas, trazendo como argumento, entre outros, o fato de que o Faraó egípcio Tarhaka tinha somente nove anos em 701 a.e.c. e, por isso, é impossível que tivesse liderado uma batalha tão importante contra os assírios. Sua opinião influenciou muitos pesquisadores.

2. Alguns dos pesquisadores que acreditaram na realização de somente uma campanha Assíria:

Wellhausen ${ }^{220}$ argumentou que Ezequias e Senaquerib fizeram um acordo de rendição e que, somente após, o rei assírio dirigiu-se para a guerra contra o Egito. No caminho, repensou o acordo feito com o rei de Judá e enviou mensageiros para exigir a rendição de Jerusalém. Ao analisar os fatos dessa forma chegou à conclusão de que houve somente uma Jornada.

Schrader $^{221}$ alegou que a vitória do Egito na guerra contra a Assíria, enfraqueceu Senaquerib que, com seu exército enfraquecido, ficou impossibilitado de lutar novamente contra o Egito, ou de realizar nova batalha contra Ezequias. Por isso, na opinião de Schrader, o rei assírio não lutou para obter a rendição de Jerusalém. Ele baseou a sua hipótese no fato de que não há prisioneiros ou despojos de guerra egípcios nos relatos assírios. Ele termina com as seguintes palavras: "There is absolutely no space in the Biblical record for this subsequent campaign."

${ }^{218}$ In: Grabbe, p. 24: Dougherty, Raymond Philip. Sennacherib and the Walled Cities of Judah. Journal of Biblical Literature, 49, 1930, pp. 160-171.

${ }^{219}$ In: Grabbe, p. 24: Albright, William Foxwell. The History of Palestine and Syria. Jewish Quarterly Review 25, 1934, pp. 363-376.

${ }^{220}$ In: Grabbe, p. 21: Wellhausen, Julius. Prolegomena Zur Geschichte Israels, 2 volumes. G. Reimer, Berlim, 1878.

${ }^{221}$ In: Grabbe, p. 21: Schrader Hans. The Cuneiform Inscriptions and the Old Testament. Williams e Norgate, Londres, 1885-1888, pp. 305-336. 
Honor Leo Lazarus ${ }^{222}$ ofereceu seis versões de leitura e compreensão do texto bíblico e, no final, concluiu que não há possibilidade de determinar com certeza a realização de duas campanhas.

Tadmor $^{223}$ alegou que, a suposição de duas campanhas realizadas por Senaquerib, provém do anseio dos pesquisadores em confirmar a veracidade do relato bíblico e explicar trechos que se contradizem, e que esses não se sustentam perante uma crítica histórica.

Para Tadmor, um historiador moderno enfrenta muitas dificuldades ao tentar combinar todos os dados encontrados a respeito da Jornada de Senaquerib. Cada tipo de fonte se diferencia da outra, o que dificulta uma análise unificada. É impossível tratar todos os documentos de uma mesma forma. Uma crônica que descreve a quantidade de tributo recolhido se diferencia de uma história profética teocrática, cujo "magnífico" é muito mais importante do que a realidade, e essa se distingue de inscrições reais de um imperador dominante, cujos textos seguem um gênero literário pré-estabelecido.

${ }^{222}$ In: Grabbe, p. 24: Honor Leo Lazarus. Sennacherib's Invasion of Palestine: a Critical Source Study. Contributions to Oriental History and Philology, 12. Columbia University Press, Nova York, 1926.

${ }^{223}$ Tadmor, Hayim. Assyria, Babylonia and Judah (em hebraico). Ed.: Cogan Mordechai, The Bialik Institute, Jerusalém, 2007, pp. 255-259. 
5.2 As fontes sobre a Jornada

Existem informações de fontes variadas sobre a Jornada de Senaquerib. Como apresentado anteriormente, as dificuldades em reconstruir a Jornada não provêm da falta de dados, mas, sim, do encaixe de todos os elementos:

1. A Bíblia trata da Jornada em 155 dos 305 versículos dedicados a Ezequias. O relato é dividido desta forma: 2 Rs $18: 13-37,19: 1-37$; $2 \mathrm{Cr} 32: 1-22$; Is 22:912, 36:1-22, 37:1-38; Mq 1:9-16. ${ }^{224}$

2. Os anais de Senaquerib, ${ }^{225}$ em suas três versões. Foram encontrados três prismas: o primeiro, "O Prisma de Taylor" de $38,5 \times 16,5 \mathrm{~cm}$, datado de aproximadamente 700 a.e.c., encontra-se hoje no British Museum, em Londres; o segundo, que mede $31 \times 17 \mathrm{~cm}$, é datado de aproximadamente 691 a.e.c. e está no Museu de Israel, em Jerusalém; o terceiro, que mede 38x14cm, aproximadamente de 689 a.e.c., está hoje no Oriental Institute, em Chicago. Austen Henry Layard descobriu os anais em 1847, em Tel Nínive, no Iraqe. ${ }^{226}$ Os anais estão escritos em acádico cuneiforme sobre prismas de barro e relatam as oito Jornadas realizadas por Senaquerib. Existem pequenas diferenças na descrição das Jornadas em cada prisma, mas no que se refere à terceira Jornada, em Canaã, os detalhes são iguais. ${ }^{227}$

\footnotetext{
${ }^{224}$ Kaplinski, Baruch. Hezekiah the Fourteenth King of the Davidic Dynasty and his Period (em hebraico), Israel Society for Biblical Research, Tel Aviv, 1990, p. 262.

${ }^{225}$ Vide anexo 10.

${ }^{226}$ Layard, Austen Henry, Discoveries among the Ruins of Nineveh and Babylon. Harper e Bros. Londres, 1853, pp. 117-126.

${ }^{227}$ Tadmor, Hayim. Assyria, Babylonia and Judah (em hebraico). Ed.: Cogan Mordechai, The Bialik Institute, Jerusalém, 2007, pp. 256-257.
} 
3. Os relevos encontrados por Austen Henry Layard no palácio de Senaquerib, em Nínive, têm aproximadamente $18 \mathrm{~m} \times 2,5 \mathrm{~m}^{228}$ e descrevem, com riqueza de detalhes, o exército assírio; a conquista de Laquish; os habitantes da cidade como prisioneiros de guerra deportados; os prisioneiros que passam em frente ao trono de Senaquerib com a inscrição: "Sennacherib, the mighty king, king of the country of Assyria, sitting on the throne of judgment, before (or at the entrance of) the city of Lachish (Lakhisha). I give permission for its slaughter."229

${ }^{229}$ Layard, Austen Henry, Discoveries among the Ruins of Nineveh and Babylon. Harper e Bros. Londres, 1853, p. 128. 
5.2.1 O relato bíblico

O relato bíblico não traz informação militar detalhada sobre a Jornada de Senaquerib.

Como já mencionado, ${ }^{230}$ os redatores de Reis tinham como meta mostrar as ações dos reis em relação à concentração do culto em Jerusalém e, também, indicar os pecados que, cumulativos, trouxeram a destruição de Jerusalém.

A meta do cronista era apresentar a casa de Davi como a única dinastia legítima, livre de pecados. Assim, os eventos históricos descritos em Crônicas, aparecem somente para que o leitor possa entender que a ordem dos acontecimentos que envolvem o povo é resultado direto da ação de Deus.

${ }^{230}$ Vide capítulo 1.4 e seus subitens. 


\subsubsection{Reis}

Ao narrar os acontecimentos do Reino de Judá, antes da Jornada de Senaquerib, o redator exclui a descrição de todas as reformas feitas por Ezequias. Com isso, não há exposição da fortificação de Jerusalém, ou da escavação do túnel na cidade. Uma única frase refere-se a esses feitos, em 2Reis 20:21: “...e como construiu o reservatório e o aqueduto para levar água à cidade."231

No relato da Jornada de Senaquerib contra Judá, o redator atende à necessidade de falar sobre seu componente militar, somente com a descrição da conquista das cidades de Judá, e a submissão de Ezequias. Não especifica quais foram essas cidades, quantas haviam sido tomadas e como se defendiam dos assírios:

"No décimo quarto ano do rei Ezequias, Senaquerib, rei da Assíria, subiu contra todas as cidades fortificadas de Judá e apoderou-se delas.,232

A rendição de Ezequias e a relação dos tributos por ele entregues a Senaquerib são destacadas com as palavras:

'... 'Cometei um erro! Retira-te de mim e aceitarei as condições que me impuseres.' $O$ rei da Assíria exigiu de Ezequias, rei de Judá, trezentos talentos de prata e trinta talentos de ouro, e Ezequias entregou toda a prata que se achava no Templo de lahweh e nos tesouros do palácio real..233

Para alguns de outros eventos não militares, o redator de Reis dedica vasto espaço. Como, por exemplo, o discurso de Ravshaka ${ }^{234}$ com seu impacto sobre o

\footnotetext{
${ }^{231}$ Bíblia de Jerusalém, 2006, p. 537.

232 2Rs 18:13, Bíblia de Jerusalém, 2006, pp. 532-533.

${ }^{233}$ 2Rs 18:14-15, Bíblia de Jerusalém, 2006, p. 533.

${ }^{234}$ 2Rs 18:17-37. No texto original em hebraico, as pessoas que Senaquerib manda a Jerusalém aparecem desta

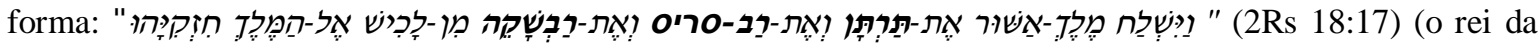
Assíria mandou Tartan, Rav-Saris e Ravshaka de Laquish...) Na Bíblia de Jerusalém, 2006, p. 533 assim: "De Laquish, o rei da Assíria mandou ao rei Ezequias, em Jerusalém, o comandante-chefe, o grande
} 
povo de Judá, e, ainda, a explanação da importância do profeta Isaías como mensageiro de Deus que luta pela continuidade da casa de Davi:

"De Laquish, o rei da Assíria mandou ao rei Ezequias, em Jerusalém, o comandantechefe, o grande eunuco, o copeiro-mor com um forte contingente de homens... Dizei a Ezequias: Assim fala o grande rei, o rei da Assíria... Em que, pois, depões tua confiança, para te teres revoltado contra mim? Confias no apoio do Egito, esse caniço quebrado, que penetra e fura a mão de quem ele apóia... Então o copeiro-mor se pôs de pé e, gritando em alta voz, em língua judaica, disse: 'Escutai a palavra do grande rei, o rei da Assíria...Que Ezequias não alimente vossa confiança em lahweh... não deis ouvidos a Ezequias... Fazei as pazes comigo, rendei-vos, e cada qual poderá comer o fruto da sua vinha e da sua figueira...até que eu venha para vos transportar para uma terra como a vossa...para que possais viver e não morrer. Mas não deis ouvidos a Ezequias, que vos ilude...' Ao ouvir essas coisas, o rei Ezequias rasgou suas vestes, cobriu-se de pano de saco..." 235

"Os ministros do rei Ezequias foram ter com Isaías, e este lhes disse: 'Direis a vosso senhor: Assim fala lahweh: Não tenha medo das palavras que ouviste... ele não há de entrar nesta cidade, nela não lançará flecha, não empunhará escudo contra ela, nem acumulará contra ela os terraplenos... Protegerei esta cidade e a salvarei em atenção a Mim mesmo e a Meu servo Davi'. .236

eunuco, o copeiro-mor." Na Bíblia de Jerusalém, os nomes que foram entendidos como funções, dentro da corte do rei da Assíria, foram traduzidos para o português. Tadmor, Hayim. ימי הבית הראשון ושיבת ציון (O Período do Primeiro Templo e o Retorno a Sião). In: History of the Jewish People, The Ancient Times. Ed.: Ben Sasson e Hayim Hilel, Devir. Tel Aviv, 1969, p. 144, traduz esses nomes da seguinte forma: Tartan = primeiro ministro do exército; Rav-Saris = comandante do exército; Ravshaka = ministro do exército de alto escalão. Mesmo assim, continua referindo-se a eles pelos nomes que aparecem no relato bíblico, e não por sua função. Neste trabalho, optamos por usar o critério de Tadmor e escrever os nomes originais de forma transliterada.

2352 Rs 18:17-35, 19:1, Bíblia de Jerusalém, 2006, pp. 533-534.

236 2Rs 19:5-34, Bíblia de Jerusalém, 2006, p. 536. 


\subsubsection{Crônicas}

O cronista não relata a conquista de nenhuma cidade em Judá nem descreve a devastação causada por Senaquerib em sua Jornada. Sobre ela, há somente:

“... houve a invasão de Senaquerib, rei da Assíria. Invadiu Judá, sitiou as cidades fortificadas com o propósito de conquistá-las." $(2 \mathrm{Cr} 32: 1)^{237}$

Quando o cronista narra o conhecimento de Ezequias a respeito da aproximação de Senaquerib, traz um relato extenso dos seus preparativos, além do seu discurso, proferido com a intenção de encorajar o povo e apresentar-se como um líder devoto a Deus:

"Vendo, então, Ezequias que Senaquerib chegava com a intenção de atacar Jerusalém, decidiu... obstruir as águas das nascentes que estavam fora da cidade... Para fortificar, Ezequias consertou todas as brechas da muralha, sobre ela construiu torres, ergueu uma segunda muralha... mandou fazer armas e escudos... Colocou generais à frente de povo... Sede firmes e corajosos; não temais, nem vos apavorais diante do rei da Assíria e diante de toda a multidão que o acompanha, pois Aquele que está conosco é mais poderoso do que aquele que está com ele. Com ele está um braço de carne, mas conosco, está lahweh, nosso Deus, que nos socorre e combate nossas batalhas. O povo ganhou confiança ao ouvir as palavras."238

O texto descreve a vinda dos mensageiros de Senaquerib a Jerusalém, sem o auxilio de forte exército, como lemos em Reis; porém, o conteúdo do discurso em hebraico é muito similar ao último.

“... Senaquerib, rei da Assíria, enquanto ainda estava diante de Laquish com todas as suas tropas, enviou seus servos a Jerusalém, para dizer a Ezequias, rei de Judá, e a todos os judeus que se achavam em Jerusalém.... Bradavam em alta voz, usando a

\footnotetext{
${ }^{237}$ Bíblia de Jerusalém, 2006, p. 620.

${ }^{238}$ 2Cr 32:2-8, Bíblia de Jerusalém, 2006, p. 620.
} 
língua judaica, dirigindo-se ao povo que estava sobre a muralha, para atemorizá-lo e intimidá-lo e, assim, apoderarem-se da cidade..."239

Em Crônicas, não há relato do luto de Ezequias, após ouvir as palavras de Senaquerib, como também da rendição do rei de Judá, ou do tributo pago ao rei da Assíria, que incluiu os portões do Templo. Seguindo a redação do cronista, ${ }^{240}$ podese deduzir que a exclusão desses detalhes foi proposital, para não macular a imagem e as conquistas de Ezequias, alcançadas com suas reformas.

${ }^{239} 2 \mathrm{Cr}$ 32:9-19, Bíblia de Jerusalém, 2006, p. 620.

${ }^{240}$ Vide Capítulo 1.4.2. 


\subsubsection{Os profetas Isaías e Miquéias}

Isaías relata em poucas palavras a Jornada de Senaquerib. Ele não se refere à sua trajetória, à conquista de Laquish, ao cerco de Jerusalém, ou aos seus devastadores resultados. Apesar disso, há alguns trechos que repetem a descrição de caráter militar de Reis:

"No décimo quarto ano do rei Ezequias, subiu Senaquerib, rei da Assíria, contra todas as cidades fortificadas de Judá e as ocupou"241 (Is 36:1, corresponde a 2Rs 18:13.) “... o rei da Assíria que combatia contra Lebona... tinha ouvido dizer que o rei havia abandonado Laquish, por ter recebido um recado a respeito de Taraca, rei de Cuch, dizendo: 'Ele partiu para a guerra contra ti'."242 (Is 37:8-9, corresponde a 2Rs 18:89.)

"O anjo de lahweh saiu e feriu cento e oitenta e cinco mil homens no acampamento dos assírios. De manhã, ao despertar, só havia cadáveres. Senaquerib, rei da Assíria, levantou acampamento e partiu."243 (Is 37:36-37 corresponde a 2Rs 19:35-36.)

Isaías destaca os discursos que fazem parte de uma guerra psicológica, como também a sua própria profecia de consolo. Assim, há:

O discurso de Ravshake, ${ }^{244}$ em Is $36: 4-20:$

“... Em quem puseste a tua confiança, para te rebelares contra mim? No mínimo, estás confiando no apoio dessa cana quebrada que é o Egito... falando na língua judaica clamou em voz alta: 'Ouvi as palavras do grande rei, do rei da Assíria'..."245

\footnotetext{
${ }^{241}$ Bíblia de Jerusalém, 2006, p. 1307.

${ }^{242}$ Idem, p. 1309.

243 Idem p. 1311

${ }^{244}$ Vide nota 234.

${ }^{245}$ Bíblia de Jerusalém, 2006, p. 1308.
} 
O discurso dos mensageiros de Senaquerib, em Is 37:9-13:

"Senaquerib tornou a enviar mensageiros a Ezequias com este recado: 'Direis a Ezequias, rei de Judá: Não te engane o teu Deus, em quem confias, dizendo: Jerusalém não será entregue nas mãos do rei da assíria'..."246

A profecia de Isaías, sobre a salvação de Jerusalém, apresenta o ditador Senaquerib como alguém que não possuiu qualquer força perante Deus e cujas ameaças são em vão. Essa profecia mostrou a profunda fé na salvação de Deus, e fortaleceu o rei e o povo para que resistissem o ataque assírio. ${ }^{247}$ Em Is 37:22-35:

“... Quanto ao rei da Assíria, eis o que diz lahweh: ‘Ele não entrará nesta cidade, não atirará contra ela uma flecha, não a atacará com escudos, não a cercará de trincheiras. Pelo mesmo caminho por que veio, voltará'..."248

Em Miquéias 1:9-16, há o relato de uma invasão que atingiu as cidades no caminho de Laquish a Jerusalém.

Alguns pesquisadores ${ }^{249}$ relacionam essa narrativa à Jornada de Senaquerib, em 701 a.e.c., e destacam que é o único lugar da Bíblia que cita a relação das cidades de Judá conquistadas por Senaquerib:

“... sim ele chegou até Judá... até em Jerusalém! Em Gat... em Soco... Em Bet Leafra... Safir... Saanã... Bet-Esel... Marot... Laquish... Morasti-Gat... Bet-Aczib... Maresa... Odolam....250

\footnotetext{
${ }^{246}$ Idem, p. 1309.

${ }^{247}$ Uffenheimer, Benjamin. The Religious Significance of the Temple and Jerusalem, (em hebraico). In: The History of Jerusalem. Ed.: Ahituv Shmuel e Mazar Amihai, Yad Ben-Zvi, Jerusalém, 2000, p. 186.

${ }^{248}$ Bíblia de Jerusalém, 2006, pp. 1310-1311. Esse trecho é uma repetição exata de 2Rs 19:20-34.

${ }^{249}$ Aharoni, Yohanan. The Land of Israel in Biblical Times a Historical Geography, (em hebraico), The Bialik Institute, Jerusalém, 1962, pp. 312-316; Mazar Binyamin. Sennacherib’s Judean Campaign (em hebraico). In: The Military History of the Land of Israel in Biblical Times. Ed.: Jacob Liver, Maarachot, Tel Aviv, $4^{\mathrm{a}}$ edição 1968, pp. 290-291; Bíblia de Jerusalém, 2006, pp. 1634-1635 nota de rodapé: e.

${ }^{250}$ Bíblia de Jerusalém, 2006, p. 1635.
} 


\subsubsection{Os Anais de Senaquerib}

Senaquerib descreve, em seus anais, a incursão militar que realizou na Síria (the Hittite-land) e em Israel (Amurru) no seu terceiro ano de reinado, em 701 a.e.c. A descrição da Jornada é composta de seis partes: ${ }^{251}$

A primeira parte traz a investida contra Lulê, rei de Sidon, e a conquista do seu reinado sem resistência. O rei foi deportado e em seu lugar foi colocado Tuba'lu para servir ao rei assírio.

"In my third campaign, I went against the Hittite-land. Lulê, king of Sidon, the terrifying splendor of my sovereignty overcame him, and far off into the midst of the sea he fled. There he died. Great Sidon, Little Sidon, Bît-Zitti, Zaribtu, Mahalliba, Ushu, Akzib, Akko, his strong, walled cities, where there were fodder and drink, for his garrisons, the terrors of the weapon of Assur, my lord, overpowered them and they bowed in submission at my feet. I seated Tuba'lu on the royal throne over them, and tribute, gifts for my majesty; I imposed upon him for all time, without ceasing."252

No relato acima, há quatro elementos que normalmente aparecem nos anais assírios ao descrever uma luta contra um inimigo rebelde: o destino do rei inimigo nesse caso a fuga e a morte do rei Lulê; a captura de sua capital e das outras cidades do seu reinado; a colocação de um vassalo leal à Assíria no lugar do rei derrotado; a determinação de tributos fixos. ${ }^{253}$

\footnotetext{
${ }^{251}$ Tadmor, Hayim. Assyria, Babylonia and Judah (em hebraico). Ed.: Cogan Mordechai, The Bialik Institute, Jerusalém, 2007, pp. 263-272.

${ }^{252}$ Luckenbill, Daniel David. The Annals of Sennacherib. Oriental Institute Publications 2. Chicago: Univ. of Chicago, 1924, pp. 27-31, coluna 2, linhas 37-49.

${ }^{253}$ Tadmor, Hayim. Assyria, Babylonia and Judah (em hebraico). Ed.: Cogan Mordechai, The Bialik Institute, Jerusalém, 2007, pp. 263-272.
} 
A segunda parte da Jornada descreve a rendição voluntária de oito reis da região. Como esses reis não lutaram e não fugiram, não há necessidade de um relato longo e detalhado. ${ }^{254}$

"From Menachem, the Shamsimurunite, Tuba'lu the Sidonite, Abdi-liti the Arvadite, Uru-milki the Gublite, Mitinti the Ashdodite Budu-ilu the Beth Ammonite, Kammusunadbi the Moabite, Malik-rammu the Edomite, kings of Amurru, all of them, numerous presents as their heavy tribute, they brought before me for the fourth time, and kissed my feet." ${ }^{255}$

A terceira parte desses anais conta o castigo imposto a Sidká, o rei de Ashkelon, que não se rendeu:

"But Sidka, the king of Ashkelon, who had not submitted to my yoke, the gods of his father's house, himself, his wife, his sons, his daughters, his brothers, the seed of his paternal house, I tore away and brought to Assyria. Sharru-lu-dari, son of Rukibti, their former king, I set over the people of Ashkelon, and I imposed upon him the payment of tribute: presents to my majesty. He accepted my yoke. In the course of my campaign, Beth-Dagon, Joppa, Banaibarka, Asuru, cities of Sidka, who had not speedily bowed in submission at my feet, I besieged, I conquered, I carried off their spoil."256

Nesse caso, há uma modificação na construção do relato: descreve a captura do rei e sua deportação para a Assíria; a substituição do rei derrotado por um leal vassalo e os altos tributos cobrados; e, somente depois de tudo isso, revela o castigo dado às cidades do reinado rebelde.

A quarta parte é dedicada aos eventos em Ekron e às forças egípcias em Eltekeh. Por sua localização geográfica, ${ }^{257}$ esse relato deveria aparecer antes daquele que detalha a batalha contra Ashkelon. Mas, o escriba o colocou depois,

\footnotetext{
${ }^{254}$ Mazar Binyamin. Sennacherib's Judean Campaign (em hebraico). In: The Military History of the Land of Israel in Biblical Times. Ed.: Jacob Liver, Maarachot, Tel Aviv, $4^{a}$ edição, 1968, pp. 289-291.

${ }^{255}$ Luckenbill, Daniel David. The Annals of Sennacherib. Oriental Institute Publications 2. University of Chicago Press, Chicago, 1924, pp. 27-31, coluna 2, linhas 50-60.

${ }^{256}$ Idem, pp. 27-31, coluna 2, linhas 60-72.

${ }^{257}$ Vide anexo 12.
} 
para manter uma trama gradual, do simples ao complexo. Assim, a história de Ekron serve como elo entre a batalha na Filistéia e os acontecimentos em Judá: ${ }^{258}$

"The officials, nobles, and people of Ekron who had thrown Padi their king bound by oath and curse of Assyria into fetters of iron and had given him over to Hezekiah, the Judahite he kept him in confinement like an enemy their heart became afraid, and they called upon the Egyptian kings, the bowmen, chariots and horses of the king of Meluhha [Ethiopia], a countless host, and these came to their aid. In the neighborhood of Eltekeh, their ranks being drawn up before me, they offered battle. With the aid of Assur, my lord, I fought with them and brought about their defeat. The Egyptian charioteers and princes, together with the Ethiopian king's charioteers, my hands captured alive in the midst of the battle. Eltekeh and Timnah I besieged, I captured, and I took away their spoil. I approached Ekron and slew the governors and nobles who had rebelled, and hung their bodies on stakes around the city. The inhabitants who rebelled and treated (Assyria) lightly I counted as spoil. The rest of them, who were not guilty of rebellion and contempt, for whom there was no punishment, I declared their pardon. Padi, their king, I brought out to Jerusalem, set him on the royal throne over them, and imposed upon him my royal tribute."259

Nesse trecho não há um rei rebelde e, por isso, somente três dos quatro componentes de um relato militar aparecem: os rebeldes recebem castigo e sua capital é conquistada; um vassalo leal é colocado para governar - que nesse caso é o próprio rei; tributos são fixados.

Provavelmente, a verdadeira ordem dos acontecimentos não é a que vem descrita nos anais. Senaquerib não teria libertado Padi de sua prisão em Jerusalém, sem a rendição de Ezequias. Por isso, pode-se perceber que o escriba relatou, nesse segmento, um acontecimento posterior, para manter o formato préestabelecido da trama. ${ }^{260}$

\footnotetext{
${ }^{258}$ Tadmor, Hayim. Assyria, Babylonia and Judah (em hebraico). Ed.: Cogan Mordechai, The Bialik Institute, Jerusalém, 2007, pp. 263-277.

${ }^{259}$ Luckenbill, Daniel David. The Annals of Sennacherib. Oriental Institute Publications 2. University of Chicago Press, Chicago, 1924, pp. 27-36, coluna 2, linhas 73-83, coluna 3, linhas 1-17.

${ }^{260}$ Tadmor, Hayim. Assyria, Babylonia and Judah (em hebraico). Ed.: Cogan Mordechai, The Bialik Institute, Jerusalém, 2007, pp. 266-267.
} 
A quinta parte do texto é dedicada ao castigo de Ezequias. O leitor que segue o texto desde o começo esperaria ler, nessa parte, um relato de acontecimentos composto pelos quatro elementos de uma incursão militar assíria. Em vez disso, há uma descrição detalhada dos cercos e conquistas das quarenta e seis cidades do Reino de Judá, mas não de Jerusalém - da qual só se fala do bloqueio de acesso à cidade pelo exército assírio, mas não de um cerco.

O escriba assírio enfrentou um desafio. Havia um esquema para descrever a rendição de um rei inimigo. Nesse, somente um rebelde fugitivo não foi corretamente castigado. No caso de Ezequias, o rei rebelde não fugiu, não foi deposto, sua capital não foi conquistada e o reinado não se tornou província assíria. O escriba, então, usou uma figuração literária para descrever o castigo: Ezequias ficou preso dentro da cidade como um pássaro na gaiola. ${ }^{261}$

"As for Hezekiah the Judahite, who did not submit to my yoke: forty-six of his strong, walled cities, as well as the small towns in their area, which were without number, by leveling with battering-rams and by bringing up siege-engines, and by attacking and storming on foot, by mines, tunnels, and breeches, I besieged and took them. 200,150 people, great and small, male and female, horses, mules, asses, camels, cattle and sheep without number, I brought away from them and counted as spoil. (Hezekiah) himself, like a caged bird I shut up in Jerusalem, his royal city. I threw up earthworks against him the one coming out of the city-gate; I turned back to his misery."262

O escriba conclui o relato com os dois últimos elementos: o castigo dado às cidades do reinado rebelde e a atribuição de tributos fixos, como era esperado; porém, diferente de outras conquistas, esse tributo, que é extremamente pesado,

${ }^{261}$ Grabbe, Lester L. Like a bird in a cage, the Invasion of Sennacherib in 701 ECE. Ed.: Grabbe Lester. L., T\&T Clark International, Londres, 2003, pp. 2-36; Tadmor, Hayim. Assyria, Babylonia and Judah (em hebraico). Ed.: Cogan Mordechai, The Bialik Institute, Jerusalém, 2007 pp. 267-268.

${ }^{262}$ Luckenbill, Daniel David. The Annals of Sennacherib. Oriental Institute Publications 2. University of Chicago Press, Chicago, 1924, pp. 31-36, coluna 3, linhas 18-30. 
não é dado para o rei assírio no campo de batalha, mas levado para Nínive, sua capital. $^{263}$

"His cities, which I had despoiled, I cut off from his land, and to Mitinti, king of Ashdod, Padi, king of Ekron, and Silli-bêl, king of Gaza, I gave (them). And thus I diminished his land. I added to the former tribute, and I lad upon him the surrender of their land and imposts gifts for my majesty. As for Hezekiah, the terrifying splendor of my majesty overcame him, and the Urbi and his mercenary troops, which he had brought in to strengthen Jerusalem, his royal city, deserted him. In addition to the thirty talents of gold and eight hundred talents of silver, gems, antimony, jewels, large carnelians, ivory-inlaid couches, ivory-inlaid chairs, elephant hides, elephant tusks, ebony, boxwood, all kinds of valuable treasures, as well as his daughters, his harem, his male and female musicians, which he had brought after me to Nineveh, my royal city. To pay tribute and to accept servitude, he dispatched his messengers."264

263 Tadmor, Hayim. Assyria, Babylonia and Judah (em hebraico). Ed.: Cogan Mordechai, The Bialik Institute, Jerusalém, 2007, pp. 267-269.

${ }^{264}$ Luckenbill, Daniel David. The Annals of Sennacherib. Oriental Institute Publications 2. University of Chicago Press, Chicago, 1924, pp. 31-36, coluna 3, linhas 31-49. 


\subsubsection{Os relevos de Laquish}

A conquista de Laquish por Senaquerib é, talvez, o evento melhor documentado do período da monarquia. Os relevos de Laquish ${ }^{265}$ foram gravados numa parede central do palácio real de Senaquerib, em Nínive, e apresentam a conquista de Laquish de forma extensa e detalhada. Esse fato trouxe um questionamento entre os pesquisadores: Por que Senaquerib atribuiu tanta importância à conquista de uma cidade secundária dentro do Reino de Judá? A seguir, opiniões de alguns dos pesquisadores:

Tadmor $^{266}$ defende que os relevos foram feitos como recompensa pelo fato de Ezequias não ter sido capturado, sua capital Jerusalém não ter sido conquistada e Judá não ter se tornado província assíria. Por isso, Senaquerib teria mandado fazer uma descrição extremamente detalhada e majestosa da conquista de Laquish, mostrando, assim, que sua Jornada teve enorme sucesso.

Ussishkin $^{267}$ defende que Laquish não foi simplesmente uma cidade fortificada dentro do Reino de Judá, mas, sim, serviu como sua segunda capital. Seu tamanho e suas fortificações demonstram sua importância.

Finkelstein e Silberman ${ }^{268}$ relatam uma Jornada de destruição da economia do Reino de Judá. Laquish, que se localizava no mais fértil território agrícola do reino, foi, depois de Jerusalém, o centro do município mais importante de Judá. O ataque

\footnotetext{
${ }^{265}$ Vide anexo 11.

${ }^{266}$ Tadmor, Hayim. Assyria, Babylonia and Judah (em hebraico). Ed.: Cogan Mordechai, The Bialik Institute, Jerusalém, 2007, pp. 270-271.

${ }^{267}$ Ussishkin, David. The Conquest of Lachish by Sennacherib, Tel Aviv University, Tel Aviv, 1982, p. 27.

${ }^{268}$ Finkelstein, Israel e Silberman, Niel Asher. The Bible Unearthed Archaeology's New Vision of Ancient Israel and the Origin of its Sacred Texts (em hebraico), Tel Aviv University, Tel Aviv, 2003, pp. 257-260.
} 
de Senaquerib à cidade teve a intenção de destruí-la completamente e deixar Judá sem provisões.

O relevo foi composto por painéis desenhados e depois gravados a partir de um rascunho feito por um artista assírio, durante o cerco em Laquish. O desenho mostra a topografia exata da cidade, bem como sua vegetação. As escavações feitas no local confirmam a veracidade do evento desenhado. Os painéis foram colocados um ao lado do outro, contando, assim, a história de Laquish da esquerda para a direita: ${ }^{269}$

Os dois primeiros painéis mostram os vários componentes do exército assírio, colocados diante de Laquish em três linhas: na primeira linha, os atiradores, os arqueiros e os escudeiros; na segunda linha, arqueiros; e, na terceira linha, arqueiros e soldados munidos de lanças.

O relevo retrata as duas muralhas da cidade com suas torres de defesa. Todos os componentes do cerco estão ilustrados em detalhes: aríetes arrastados para o portão sobre rampas construídas pelos soldados assírios. Esses intensamente atacados com tochas pelos defensores da cidade, enquanto os atacantes devolviam fogo com suas flechas. Vê-se também a tentativa de escalar as muralhas por escadas, com a proteção dos arqueiros, atiradores, lanceiros e escudeiros.

Apesar do ataque ainda estar ocorrendo, já é possível ver, nesse mesmo painel, prisioneiros de Laquish saindo da cidade, atravessando seu portão.

O retrato continua, mostrando as famílias de Laquish indo para o exílio, levando consigo o despojo de guerra a ser entregue para Senaquerib. A ilustração mostra, com detalhes, a crueldade dos soldados assírios no caminho ao exílio.

\footnotetext{
${ }^{269}$ Bustenai, Oded. יהודה ואשור (Judá e Assíria), Open University, Tel Aviv, 1984, pp. 24-27.
} 
Ao chegar a Nínive, são recebidos por Senaquerib, sentado em seu trono. Nele está a inscrição que possibilitou a identificação desse relevo com a Jornada de Senaquerib contra Laquish. ${ }^{270}$

${ }^{270}$ Vide Capítulo 5.2. 


\subsection{As conseqüências da Jornada}

Apesar de não ter conquistado totalmente Reino de Judá, ou Jerusalém, Senaquerib deixou Judá devastada. Diversas cidades não conseguiram se reerguer, por muitos anos, após essa Jornada, como por exemplo, a cidade de Laquish. ${ }^{271}$

Muitas das cidades do Reino de Judá, que Senaquerib havia conquistado, foram divididas por ele entre os reis de Ashdod, Ekron e Gaza. Essa ação, que fortaleceu as cidades filistéias por conta de Judá, demonstra uma nova tática do rei assírio, que era diferente daquela usada por Saragon, seu pai.

Como Senaquerib foi obrigado a guerrear contra reinados ao nordeste do rio Eufrates, preferiu deixar na região reinados que, apesar de submissos a ele e pagadores de tributos, sustentavam certo grau de independência. Assim, não houve necessidade de deixar um exército ou um rei assírio para governar o local. Dessa forma, criou uma zona de segurança entre a Assíria e o Egito.

A cristalização da situação político-militar na Filistéia, o cuidado em manter um delicado equilíbrio entre as quatro principais cidades filistéias e a diminuição da importância de Judá na região, podem explicar a tranqüilidade em Canaã durante os vinte anos seguintes. ${ }^{272}$

\footnotetext{
${ }^{271}$ Ussishkin, David. Answers at Lachish, Biblical Archaeology Review, Nov/Dez. 1979, pp. 16-39.

${ }^{272}$ Tadmor, Hayim. Assyria, Babylonia and Judah (em hebraico). Ed.: Cogan Mordechai, The Bialik Institute, Jerusalém, 2007, pp. 270-274.
} 
Considerações finais

Um princípio do mundo judiciário determina que, aquele que não esteve presente no momento que um delito foi cometido, não pode testemunhar a respeito do mesmo. Aparentemente, essa regra vale também para a pesquisa histórica e, de acordo com ela, quem não presenciou os acontecimentos, não pode dissertar sobre eles. A justificativa para tal pensamento é a de que a descrição de algum acontecimento, a partir do relato de terceiros, não é confiável. ${ }^{273}$

A aplicação desse princípio à pesquisa bíblica levou a uma situação de anulação do valor da Bíblia como testemunho histórico.

Os que compartilham desse pensamento, argumentam que o relato bíblico descreve, apenas, a vida e os objetivos dos próprios redatores, na época que viveram - os dias do Império Persa. ${ }^{274}$ Assim, não seriam historiadores, relatando com precisão o passado de um povo antigo, mas criadores de mitos, que escreveram com a intenção de suprir as necessidades de um povo, que se solidificava diante de seus olhos.

Se ignorarmos a Bíblia e descreveremos a situação na Idade do Ferro B2 e B3, considerando somente as descobertas epigráficas da região, descobriremos que o único povo existente entre Amon e Moab, no leste, e a Filistéia, no oeste, é o povo de Israel, com seus dois reinos, Israel e Judá. A língua desse povo é única, com

\footnotetext{
${ }^{273}$ Hurowitz, Victor Avigdor. Expelling the Bible from the Biblical Period (em hebraico). In: The Controversy over the Historicity of the Bible. Ed.: Lee Israel Levin e Mazar Amihai, Yad Ben Zvi e Dinur Center, Jerusalém, 2001, pp. 47-51.

${ }^{274}$ Idem.
} 
uma crença monoteísta, na maior parte do tempo - num Deus cujo nome é $Y H W H^{275}$

Para montar esse cenário, bem como descrever a vida religiosa, administrativa e legal da época, podemos usar as descobertas epigráficas apresentadas neste trabalho, como por exemplo: a benção dos sacerdotes de Katef Hinom; a Inscrição de Balaão, de Tell Deir'Alla; as inscrições em papiro, de Wadi Muraba'at; os selos e bullae com nomes de reis e funções administrativas, ou a inscrição do Túnel de Siloé.

Além dessas, na longa sucessão de inscrições de reis vizinhos tratadas nesta dissertação, encontraremos muitas referências aos reinos de Judá e Israel com suas capitais e seus reis. Essas descobertas epigráficas apresentam dinastias, personagens e cidades que aparecem no relato bíblico, como, por exemplo:

Na Estela de Dan, que relata uma batalha entre Hazael, o rei arameu, e os reinos de Israel - cujo rei é Jorão, filho de Acab - e Judá -- cujo rei é Ocozias, filho de Jorão, da Casa de Davi. ${ }^{276}$

Na Estela de Mesha, onde aparece Mesha como o rei de Moab, há o relato da libertação do domínio de Omri, rei de Israel; e uma narrativa sobre os filhos de Gad, que habitavam essa região. ${ }^{277}$

No Obelisco Negro, o rei de Israel é Yahu, e o rei de da Assíria Shalmanesser III. ${ }^{278}$

Nos anais de Tiglat Pilesser III, o rei de Aram-Damasco é Ratzin; o rei de Israel é Manaém; o rei de Tiro é Hiram; e o rei de Judá é Acaz. ${ }^{279}$

\footnotetext{
275 Idem

276 1Rs 19:15; 2Rs 8:27-29; 2Cr 22:5-7.

277 2Rs 3:4-5.

${ }^{278}$ 2Rs 9:2-3; 2 Cr 22:7.

${ }^{279}$ 2Rs 15:17-20.
} 
No Prisma de Senaquerib, ao lado do relato que traz Ezequias como o rei de Judá, ${ }^{280}$ aparece uma longa lista de reis da região e suas cidades.

Os relevos de Laquish são de especial interesse. Apresentam um singular paralelo de dados arqueológicos e bíblicos, através do pictórico e do escrito. Dessa forma, relatam de maneira extremamente detalhada a conquista de Laquish por Senaquerib. ${ }^{281}$

Com isso, podemos aceitar a existência desses reis e conhecer, em parte, a vida espiritual e ideológica da época, mas não os fatos e acontecimentos detalhados da vida de cada um deles. Portanto, ao analisar esses vestígios sem o texto bíblico, não saberíamos quem foram essas pessoas e qual foi a relação entre elas. ${ }^{282}$

A análise realizada nesse trabalho apresentou paralelos entre o relato bíblico e as fontes extra-bíblicas a respeito da língua, religião, cultura e vida cotidiana. Ainda que haja divergências entre as fontes, não podemos alegar que a Bíblia é somente uma junção de histórias populares e mitos. Contudo, se quisermos "olhar" a Bíblia como testemunho, devemos fazê-lo com muita cautela.

\footnotetext{
${ }^{280}$ 2Rs 18:13; 2Rs 16:5-9; Is 36:1-2 e outros.

${ }^{281}$ Is 37:8; 2 Rs 18:14 e outros.

${ }^{282}$ Zakovitch, Yair. Words, Stones, Memory, and Identity (em hebraico). In: The Controversy over the Historicity of the Bible. Ed.: Lee Israel Levin e Mazar Amihai, Yad Ben Zvi e Dinur Center, Jerusalém, 2001, pp. 66-74.
} 


\section{Bibliografia Geral}

AHARONI, Yohanan. The Land of Israel in Biblical Times a Historical Geography (em hebraico), The Bialik Institute, Jerusalém, 1962.

The Land of the Bible a Historical Geography - translated from the Hebrew by A. F. Rainey, Ed.:Burns e Oates, Londres, 1968.

ALBRIGHT, William Foxwell. The Archaeology of Palestine (em hebraico), Daat, Tel Aviv, 1951.

BEN SASSON, Haim Hilel. Organizador, History of the Jewish People, Devir, Tel Aviv, 1969.

BRIGHT, John. História de Israel, 7ª edição, Paulus, São Paulo, 2003.

DE VAUX, Ronald. חי" יום יום בישראל בימי המקרא (A Vida Cotidiana em Israel na Época da Bíblia), Volume 1, Ed.: Massada e Am Hassefer, Tel Aviv, 1969.

FINKELSTEIN, Israel e SILBERMAN, Niel Asher. The Bible Unearthed Archaeology's New Vision of Ancient Israel and the Origin of its Sacred Texts (em hebraico), Tel Aviv University, Tel Aviv, 2003.

GRANT, Michael. The History of Ancient Israel, Weidenfeld e Nicolson, Londres, 1996.

GUTTMAN, Julius. Philosophie des Judentums, tradução para hebraico: Baruch, I. L., Ed.:Vislevsky, Zvi. Bialik, Jerusalém, 1951, 5ª̣ edição, 1999.

HAR-EL, Menashe. The Ancient Landscapes of the Land of Israel (em hebraico), Kineret, Zmora-Bitan, Dvir, Or Yehuda, 2005.

KAUFMANN, Yehezkel. A Religião de Israel, Perspectiva, São Paulo, 1989.

MAZAR, Amihai. Arqueologia na terra da Bíblia 10.000-586 a.C., Paulinas, São Paulo, 2003.

NEGEV, Avraham. Archaeology in the Land of the Bible, Sadan, Tel Aviv, 1976.

ROFÉ, Alexander. Introduction to the Composition of the Pentateuch, Sheffield Academic Press, Londres, 1999.

VILNAY, Zev. ירושלים בירת ישראל, העיר העתיקה (Jerusalém, a Capital de Israel, a Cidade Velha), Volume 1, Achiever, Jerusalém, 1970.

ירושלים בירת ישראל העיר העתיקה וoביבתה. (Jerusalém, a Capital de Israel, a Cidade Velha e seus Arredores), Volume 2, Achiever, Jerusalém, 1972. 


\section{Bibliografia Específica}

AHITUV, Shmuel. כתובות עבריות מירושלים של ימי בית ראשון (Inscrições Hebraicas de Jerusalém do Período do Primeiro Templo). In: ירושלים בימי בית ראשון עים (Jerusalém no Período do Primeiro Templo). Ed.:Naor Mordechai, Yad Ben Zvi, Jerusalém, 1990, pp. 90-101.

AMIRAN, Ruth. The Water Supply of Israelite Jerusalem. In: Jerusalem Revealed - Archaeology in the Holy City 1968-1974, The Israel Exploration Society, Jerusalém, 1975, pp. 75-78.

AVIGAD, Nahman. Excavations in the Jewish Quarter of the Old City, 19691971. In: Jerusalem Revealed - Archaeology in the Holy City 1968-1974, The Israel Exploration Society, Jerusalém, 1975, pp. 41-51.

Archaeological Discoveries in the Jewish Quarter of Jerusalem, The Israel Exploration Society e The Israel Museum, Jerusalém, 1976.

BARKAI, Gabriel. The Archaeology of Ancient Israel in the Biblical Period - The Iron Age II. Open University. Tel Aviv, 1990.

---. The Necropoli of Jerusalem in the First Temple Period, (em hebraico). In: The History of Jerusalem. Ed.: Ahituv Shmuel e Mazar Amihai, Yad Ben-Zvi, Jerusalém, 2000, pp. 233-270.

BEN-TOR, Amnon. מהי ארכיאולוגיה? פרקי מבוא (O que é Arqueologia? Capítulos de

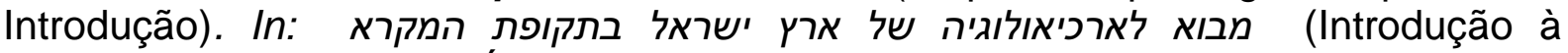
Arqueologia de Israel na Época Bíblica). Ed.: Ben-Tor Amnon, Open University, Tel Aviv, 1989, pp. 45-48.

Archaeology-Bible-History. (em hebraico) In: The Controversy over the Historicity of the Bible. Ed.: Lee Israel Levin e Mazar Amihai, Yad Ben Zvi e Dinur Center, Jerusalém, 2001, pp.17-25.

BEN-DOV, Meir. The Dig at the Temple Mount, Keter, Jerusalém, 1982.

BIRAM, Avraham. דברי ימי ישראל בזמן המקרא במסגרת תולדות המזרח הקדום (A História de Israel no Período Bíblico no quadro da História do Antigo Oriente), Volume 3, Beit Hassefer Hareali, Haifa, 1964.

BUSTANAI, Oded. אחרית ממלכת יהודה (O Fim do Reino de Judá), Open University, Tel Aviv, 1984.

יאשיהו ותקופתו (Isaías e sua Época), Open University, Tel Aviv, 1984.

ירושלים לדורותיה: מעיר יבוסית לבירת עם ישראל (Jerusalém e Suas Gerações: de Cidade Jebusita à Capital do Povo de Israel), Open University, Tel Aviv, 1984. 
(Introdução ao Livro de Reis: as Fontes do Livro de Reis). In: עולם התנים (O Mundo da Bíblia), Volume 1Reis, Ed.: Haran, Menhem, Divrei Hayamim, Jerusalém, 1983-1996. Disponível em: <http://lib.cet.ac.il/pages/item.asp?item=9463> (acesso em 23/04/2008).

COGAN, Mordechai. Royal City and Temple City: The History of Jerusalem from David to Josiah (em hebraico) in: The History of Jerusalem, Ed.: Ahituv Shmuel e Mazar Amihai, Yad Ben-Zvi, Jerusalém, 2000, pp. 67-84.

CROSS, Frank Moore. A Bullae of Hezekiah, King of Judah. In: Essays in the Archaeology and Biblical Interpretation in Honor of Eduard F. Campbell Jr. Ed.: Prescott H. Williams Jr. e Theodor Hiebert, Realias Dei, Scolars Press, Atlanta, Georgia, 1999, 62-66.

DAVIES, Graham. Hebrew Inscriptions. In: The Biblical World, Volume I, Ed.:John Barton, Taylor e Francis, Londres, 2002, pp. 270-286.

FEIG, Nurit. The Environs of Jerusalem in the Iron Age II (em hebraico). In: The History of Jerusalem, Ed.: Ahituv Shmuel e Mazar Amihai, Yad Ben-Zvi, Jerusalém, 2000, pp. 987-410.

GARSIEL, Moshe. מבוא לספר מלכים: מבנה הספר תוכנו ומגמתו (Introdução ao Livro de Reis: sua Estrutura, seu Conteúdo e sua Tendência). In: עולמים התנמת (O Mundo da Bíblia), Volume 1Reis, Ed.: Haran, Menhem. Divrei Hayamim, Jerusalém, 1983-1996. Disponível em: <http://lib.cet.ac.il/pages/item.asp?item=9464> (acesso em 23/04/2008).

GRABBE, Lester L. Like a bird in a cage, the Invasion of Sennacherib in 701 ECE. Ed.: Grabbe Lester L., T\&T Clark International, Londres, 2003.

GREENZVAIG, Michael. ירושלים בירת ישראל, תולדות העיר לדורותיה (Jerusalém a Capital de Israel, a História da Cidade ao Longo de suas Gerações), Meor Volach, Jerusalém, 1994.

HERZOG, Zeev, The Scientific Revolution in the Archaeology of Ancient Israel (em hebraico). In: The Controversy over the Historicity of the Bible. Ed.: Lee Israel Levin e Mazar Amihai, Yad Ben Zvi e Dinur Center, Jerusalém, 2001, pp. 52-65.

HESTRIN, Ruth e DAYAGI, Michal. A Seal Impression of a Servant of King Hezekiah. In: The Israel Exploration Journal Reader, Volume II, Ed.: Orlinsky Harry Meyer, Ktav Publishing House, Jersey City, 1981, p. 1173.

HOFFMAN, Yair. Aspects of Modern Biblical Criticism (em hebraico), Ministry of Defense, Israel, 1997.

The Study of Biblical Historiography: History, Myth, and Politics. (em hebraico) ) In: The Controversy over the Historicity of the Bible. Ed.: Lee Israel Levin e Mazar Amihai, Yad Ben Zvi e Dinur Center, Jerusalém, 2001, pp. 26-33. 
HOLLADAY John S. Jr. Hezekiah's Tribute, Long-Distance Trade, and the Wealth of Nation ca. 1000-600 BC: A New Perspective. In: Confronting the Past: Archaeological and Historical Essays on Ancient Israel in Honor of William G. Dever. Ed.: Seymour Gitin, J. Edward Wright, J.P Dessel, Eisenbrauns, EUA, 2006, pp. 309331.

HUROWITZ, Victor Avigdor. Expelling the Bible from the Biblical Period (em hebraico). In: The Controversy over the Historicity of the Bible. Ed.: Lee Israel Levin e Mazar Amihai, Yad Ben Zvi e Dinur Center, Jerusalém, 2001, pp. 47-51.

JAPHET, Sara. היסטוריה של עם ישראל, שיבת ציון - ימי שלטון פרס, ההיסטוריוגרפיה (A História do Povo de Israel, O Retorno a Sião Período do Domínio Persa, Historiografia Bíblica na Época Persa) Am Oved, Jerusalém, 1983.

The Ideology of the Book of Chronicles and its Place in Biblical Thought (em hebraico). Bialik Institute, Jerusalém, 2ª edição 1995.

The Bible and History (em hebraico). In: The Controversy over the Historicity of the Bible. Ed.: Lee Israel Levin e Mazar Amihai, Yad Ben Zvi e Dinur Center, Jerusalém, 2001, pp. 84-89.

KAPLINSKI Baruch. Hezekiah the Fourteenth King of the Davidic Dynasty and his Period (em hebraico). Israel Society for Biblical research, Tel Aviv, 1990.

KITCHEN, Kenneth Anderson. The Philistines. In: Peoples of the Old Testament Times. Ed.: Wiseman, Donald John, Oxford University Press, 1973, pp. 53-78.

LAYARD, Austen Henry, Discoveries among the Ruins of Nineveh and Babylon. Harper e Bros., Londres, 1853.

LIPSCHITS, Oded. Jerusalem between Destruction and Restoration - Judah under Babylonian Rule, (em hebraico). Yad Ben-Zvi, Jerusalém, 2004.

LUCKENBILL, Daniel David. The Annals of Sennacherib. Oriental Institute Publications 2. Chicago: University of Chicago, 1924.

Ancient Records of Assyria and Babylonia. Volume 2: Historical Records of Assyria from Sargon to the End. Chicago: University of Chicago Press, 1927.

LIVER, Jacov. המקרא והמקורות ההיסטוריים שבו (A Bíblia e suas Fontes Históricas). In: A Historia do Povo Judeu, Volume II: Os Patriarcas e os Juízes, Am Oved, Tel Aviv, 1967, pp. 31-32.

MALAMAT, Avraham. The Wars of Israel and Assyria (em hebraico). In: The Military History of the Land of Israel in Biblical Times. Ed.: Liver Jacob, Maarachoth, 4ํㅡㄹ edição, Tel Aviv, 1968, pp. 241-260. 
(O Início da Nação). In: History of the Jewish People, The Ancient Times, Volume 1, Organizador: Ben Sasson Haim Hilel, Devir. Tel Aviv, 1969, pp. 9-90.

Between Egypt and Jerusalem, and the Destruction of Jerusalem (em hebraico). In: The History of Jerusalem, Ed.: Ahituv Shmuel e Mazar Amihai, Yad Ben-Zvi, Jerusalém, 2000, pp. 85-92.

. The Dawn of Jerusalem (em hebraico). In: The History of Jerusalem, Ed.: Ahituv Shmuel e Mazar Amihai, Yad Ben-Zvi, Jerusalém, 2000, pp. 13-22.

MAZAR, Amihai. The Archaeology of Ancient Israel in the Biblical Period - The Iron Age I (em hebraico), Open University, Tel Aviv, 1990.

Jerusalem's Water Supply in the First Temple Period (em hebraico). In: The History of Jerusalem, Ed.: Ahituv Shmuel e Mazar Amihai, Yad Ben-Zvi, Jerusalém, 2000, pp. 195-232.

Comments on the Relationship between Archaeology and the Biblical Period (em hebraico). In: The Controversy over the Historicity of the Bible. Ed.: Lee Israel Levin e Mazar Amihai, Yad Ben Zvi e Dinur Center, Jerusalém, 2001, pp. 97-111.

MAZAR, Binyamin. Sennacherib's Judean Campaign (em hebraico). In: The Military History of the Land of Israel in Biblical Times. Ed.: Jacob Liver, Maarachot, Tel Aviv, 4aㅡ edição, 1968, pp. 286-295.

כנען וישראל, ממלכת ארם ויחסיה עם ישראל (Canaã e Israel, o Reinado Arameu e seu Relacionamento com Israel), The Bialik Institute, Jerusalém, 1974.

Jerusalem in the Biblical Period. In: Jerusalem Revealed Archaeology in the Holy City 1968-1974. The Israel Exploration Society, Jerusalém, 1975, pp. 1-8.

NIR, Rivka. מעיר יבוסית לבירת עם ישראל (De Cidade Jebusita à Capital do Povo de Israel), Open University, Tel Aviv, 1984.

NOTH, Martin. The Deuteronomistic History. Sheffield, Academic Press, Londres, 1981.

$\mathrm{REICH}$, Ronny. The Topography and Archaeology of Jerusalem in the First Temple Period (em hebraico). In: The History of Jerusalem. Ed.: Ahituv Shmuel e Mazar Amihai, Yad Ben-Zvi, Jerusalém, 2000, pp. 93-130.

ROFÉ, Alexander. ההיoטוריוגרפיה הנבואית (Historiografia Profética), In: Histórias dos Profetas. Magnes, Jerusalém, 1983, pp. 68-69. 
ROZENSON, Israel. ירושלים בראשיתה ובימי בית ראשון (Jerusalém no seu Início e זאת ירושלים, חלק ראשון: מראשיתה עד : זssa é Jerusalém, primeira parte: do seu Início até a Época Muçulmana). Ed.: Peleg Ruth, Yad Ben-Zvi, Jerusalém, 1995, pp. 1-82.

RUBIN, Rehav. Jerusalem and its Environs: the Impact of Geographical and Physical Conditions on the Development of Jerusalem (em hebraico). In: The History of Jerusalem. Ed.: Ahituv Shmuel e Mazar Amihai, Yad Ben-Zvi, Jerusalém, 2000, pp. 1-12.

SASS, Benjamin. Script and inscriptions in the Biblical Period (em hebraico). Open University, Tel Aviv, 1992.

Studies in the Iconography of Northwest Semitic Inscribed Seals. Fribourg University Press, Fribourg, 1993.

TADMOR, Hayim. The Assyrian Campaigns to Philistia (em hebraico). In: The Military History of the Land of Israel in Biblical Times. Ed.: Liver Jacob, 4 ${ }^{\mathrm{a}}$ edição, Maarachoth, Tel Aviv, 1968, pp. 261-285.

O Período do Primeiro Templo e o Retorno a Sião), in: History of the Jewish People, The Ancient Times. Organizador: Ben Sasson, Haim Hilel. Devir. Tel Aviv, 1969, pp. 93-173.

(A Cronologia da Época da Monarquia). In: ההיסטוריה של עם ישראל, ימי המלוכה - היסטוריה מלתינת מלינית (a História do Povo de Israel, o Período da Monarquia - História Política), Am Oved, Jerusalém, 1982, pp. 40-52, 223-225.

Mordechai, The Bialik Institute, Jerusalém, 2006.

THE ISRAEL MUSEUM, Jerusalém, Ed.: Sharon AvRutick, Harry N. Abrams, Inc. Nova York, 2005.

UFFENHEIMER, Benjamin. The Religious Significance of the Temple and Jerusalem (em hebraico). In: The History of Jerusalem. Ed.: Ahituv Shmuel e Mazar Amihai, Yad Ben-Zvi, Jerusalém, 2000, pp. 175-194.

USSISHKIN David. A recently Discovered Monolithic Tomb in Siloam. In: Jerusalem Revealed, Archaeology in the Holy City 1968-1974. The Israel Exploration Society, Jerusalém, 1975, pp. 63-65.

Tel Aviv, 1982.

The Conquest of Lachish by Sennacherib. Tel Aviv University,

VAINSTUB, Daniel. Hebrew Inscriptions of the First Temple Period, (em hebraico). In: The History of Jerusalem. Ed.: Ahituv Shmuel e Mazar Amihai, Yad Ben-Zvi, Jerusalém, 2000, pp. 271-305. 
ZAKOVITCH, Yair. Words, Stones, Memory, and Identity (em hebraico). In: The Controversy over the Historicity of the Bible. Ed.: Lee Israel Levin e Mazar Amihai, Yad Ben Zvi e Dinur Center, Jerusalém, 2001, pp. 66-74.

ZELIGMAN Itzhak Arie, יסודות אטיולוגיים בהיסטוריוגרפיה המקראית (As Bases Etiológicas na Historiografia Bíblica). In:מחקרים בתולדות ישראל בתקופת המקראי (Pesquisas da história de Israel na Época Bíblica), Ed.: Horovitz Avi, Tov Emanuel, Japhet Sara, IL Magnes, Tel Aviv, 1992, 141-169.

\section{Artigos e Periódicos:}

AHITUV, Shmuel. A Divine Verdict: A Judicial Papyrus of the Seventh Century $B C E$ (em hebraico). Eretz Israel Archaeological, Historical and Geographical Studies, Volume 26, Israel Exploration Society, Jerusalém, 1999, pp.1-4.

BARKAI, Gabriel, ברכת הכהנים על לוחית נסף מכתף הינום בירושלים (A Benção dos Sacerdotes sobre Placa de Prata de Katef Hinom em Jerusalém). Katedra 52, Jerusalém, 1989, pp. 37-76.

BIRAN, Avraham; NAVEH, Joseph. An Aramaic Stele Fragment from Tel Dan. Israel Exploration Journal 43, 1993, pp. 81-98.

Journal 45, 1995, pp. 1-18.

BROSHI, Maguen. תושביה של ירושלים בימי בית ראשון (Os Habitantes de Jerusalém no Periodo do Primeiro Templo). Idan 15, Yad Ben-Zvi, 1991, pp. 93-97.

בין חזקיהו לערי פלשת (Entre Ezequias e as Cidades Filistéias). Sefer Barslavi, Israel Society for Biblical Research, Jerusalém, 1970, pp. 79-88.

COGAN, Mordechai. שימוש כרונולוגי מכוון בפר דיברי הימים (Uso Cronológico Intencional do Livro de Crônicas). Tzion 45, Historical Society of Israel, 1983, pp. 165-172.

דת ופולחן בממלכת יהודה בימי ההגמוניה האשורית (Religião e Culto no Reino de Judá no Período do Império Assírio), Katedra 69, Yad ben-Zvi, 1993, pp. 317.

CROSS, Frank Moore. King Hezekiah's Seal Bears Phoenician Imagery. Biblical Archaeology Review 25,2, Mar/Abril 1999, pp. 42-45, 60.

FRANKEN, H. J. Vetus Testamentum, Volume 17, Fasc. 4, Outubro, 1967, pp. 480481.

GROBER, Meir. ישראל בימי קדם מנקודת מבט פוסט-קולוניאלית (Israel na Antiguidade de ponto de vista Pós-Colonial). Resling 7, Tel Aviv, verão de 2000, pp. 113-118. 
JAPHET, Sara. היבטים אחדים של הגדרת הזהות היהודית בימי בית שני: מסורת יציאת מצחים (Alguns Pontos de Vista sobre a Definição da Identidade Judaica no Período do Segundo Templo: a Tradição da Saída do Egito e a Concepção do Povo Eleito). In: מגוון דעות והשקפות בתרבות ישראל ב' (Variedade de Opiniões e Visões na Cultura de Israel II), 1992, pp. 37-61.

ספר דיברי הימים, חיבור היסטורי . (Crônicas - Redação Histórica). In: 14 (Anuário de Pesquisa Bíblica e Oriente Antigo, 14) Tanach, Israel, 2004, pp. 101-117.

MAGUIDOV, Rony. היסטוריוגרפיה (Historiografia). Mikranet, 2005. Disponível em: $<\mathrm{http}$ ://lib.cet.ac.il/pages/item.asp?item $=13168 \& \mathrm{kwd}=4024>$ (acesso em 22/05/2008).

MARGOLIS, Baruch. עלילות בלעם בר בעור מעמק Oוכות (A Trama de Balaão filho de Beor do Vale de Sucot), Al Haperek 15, outubro 1998, Ministério da Educação, Israel. pp. 3-10.

NEEMAN, Nadav. הכתובת הארמית מתל דן בהארה היסטורית (A Inscrição Aramaica de Tel Dan à luz da História). Eretz Israel Archaeological, Historical and Geographical Studies, Volume 26, Israel Exploration Society, Jerusalém, 1999, pp.112-118.

לשחזור ההיסטוריה הקדומה של עם ישראל, מקרא, ארכיאולוגיה וכתיבת . הara a Reconstituição da História Antiga do Povo de Israel, Bíblia, Arqueologia, e Escrita da História). Zemanim, 94, Jerusalém, 2006, pp. 8-19.

עלייתה של ירושלים למעמד "העיר הראשה" בממלכת יהודה במאות הח'-הז' (A Ascensão de Jerusalém para a Posição da Cidade Principal no Reino de Judá nos Séculos 8 e 7 a.e.c.), Tzion 71, Historical Society of Israel, Jerusalém 2006, pp. 410-427.

(Sobre Algumas Inscrições Hebraicas Antigas e sua Importância), Tzion 82, 2007, pp. 225-230.

RENDSBURG, Gary A. On the writing ביתדוד in the Aramaic Inscription from Tel Dan. Israel Exploration Journal 45, 1995, pp. 22-25.

SCHNIEDEWIND, William M. Tel Dan Stele: New light on Aramaic and Jehu's Revolt. Bulletin of the American Schools of Oriental Research 302, maio, 1996, pp. 75-90.

TADMOR, Haim. מלחמת Oנחריב ביהודה (A Guerra de Senequerib contra Judá). Tzion 50, Historical Societies of Israel, 1985, pp. 65-80.

TALSHIR, Tzipora. תפיסת פילוג הממלכה בפר מלכים ובספר דברי הימים (A Concepção da Cisão em Reis e Crônicas), על הפרק, 7 (Al Haperek 7), 1994, pp. 34-52.

TAKAMITSU, Muraoka. Linguistic Notes on the Aramaic Inscription from Tel Dan. Israel Exploration Journal 45, 1995, pp. 22-25. 
TOV, Emanuel. היחo בין עדי נוסח המקרא לאור מגילות מדבר יהודה (A Relação entre as Versões da Bíblia à Luz dos Pergaminhos do Mar Morto). In: Beit Hamikrá 77, Israel Society for Biblical Research, Jerusalém, 1979, pp. 161-170.

USSISHKIN, David. קנקני 'למלך' וחפירות לכיש (Os Vasos de 'Imlk' e as Escavações em Laquish). Kadmoniot 9, Israel Exploration Society, Jerusalém, 1976, pp. 63-68

pp.16-39.

Answers at Lachish. Biblical Archaeology Review, Nov/Dez., 1979, (Os Projetos de Suprimento de Água em Jerusalém nos Dias de Ezequias). Katedra 70, Yad Ben Zvi, Jerusalém, 1994, pp. 3-28.

WEINFELD, Moshe. התעוררות התודעה הלאומית בישראל במאה השביעית לפני הספירה (O Despertar da Consciência Nacionalista em Israel no Século 7 a.e.c.). In: Az Le David, Coletânea de Pesquisas da Bíblia, entregue a David Ben Gurion ao completar 77 anos, Israel Society for Biblical Research, Jerusalém, 1964, pp. 396-420.

ZAKOVITCH, Yair. פר דברי הימים נפרשן - מבוא לפרשנות פנים מקראית (Crônicas como Comentarista - Introdução aos Comentários Intra-Bíblicos), Reches, 1992. Disponível em: <http:// mikranet.cet.ac.ul /pages/item.asp ?item=7641> (acesso em 01/05/2008).

\section{Bíblias}

כתר ירושלים - תנ"ך האוניברסיטה העברית בירושלים (Keter Jerusalém - a Bíblia da Universidade Hebraica de Jerusalém), hebraico, Defus Hemed, Jerusalém, 2004.

תנ"ך - תורה, נביאים וכתובים (Bíblia - Pentateuco, Profetas e escritas), hebraico, Adi, Tel Aviv, 1996.

BíBLIA DE JERUSALÉM, português, 2ª impressão, Paulus, São Paulo, 2003.

BíBLIA DE JERUSALÉM, português, 4ª̣ impressão, Paulus, São Paulo, 2006.

BÍBLIA HEBRAICA, português, tradução do hebraico - David Gorodovits e Jairo Fridlin, Ed.: Sêfer, São Paulo, 2006.

MECHON MAMRE, hebraico, disponível em <http://www.mechon-mamre.org> 
Atlas, Enciclopédias e Dicionários

AHARONI, Yohanan. Carta's Atlas of the Bible (em hebraico), Carta, Jerusalém, 1974.

ALCALAY, Reuben, The Complete Hebrew-English Dictionary, Massada Publishung, Tel Aviv, 1965.

--.-. The Complete English-Hebrew Dictionary, Massada Publishung, Volumes 1 e 2, Tel Aviv, 1965.

ENCICLOPÉDIA BÍBLICA. Volume 4, The Bialik Institute, Jerusalém, 1962.

EVEN-SHOSHAN, Avraham. המילון העברי המרוכז (O Dicionário Hebraico Concentrado), Kiryat Sefer, Jerusalém, 1991.

BEREZIN, Rifka. Dicionário Hebraico-Português, EDUSP, São Paulo, 2003.

HATZAMRI, Abraham e MORE-HATZAMRI, Shoshana. Dicionário PortuguêsHebraico, Hebraico-Português. Aurora, Tel Aviv, 1995.

MICHAELIS, Moderno Dicionário da Língua Portuguesa, Melhoramentos, São Paulo, 1998.

\section{Metodologia}

RODRIGUES, André Figueiredo. Como Elaborar e Apresentar Monografias, Associação Editorial Humanitas, São Paulo, 2006.

--.-. Como Elaborar Citações e Notas de Rodapé, Associação Editorial Humanitas, São Paulo, 2006.

Como Elaborar Referência Bibliográfica, Associação Editorial Humanitas, São Paulo, 2006. 
Anexos:

Anexo 1

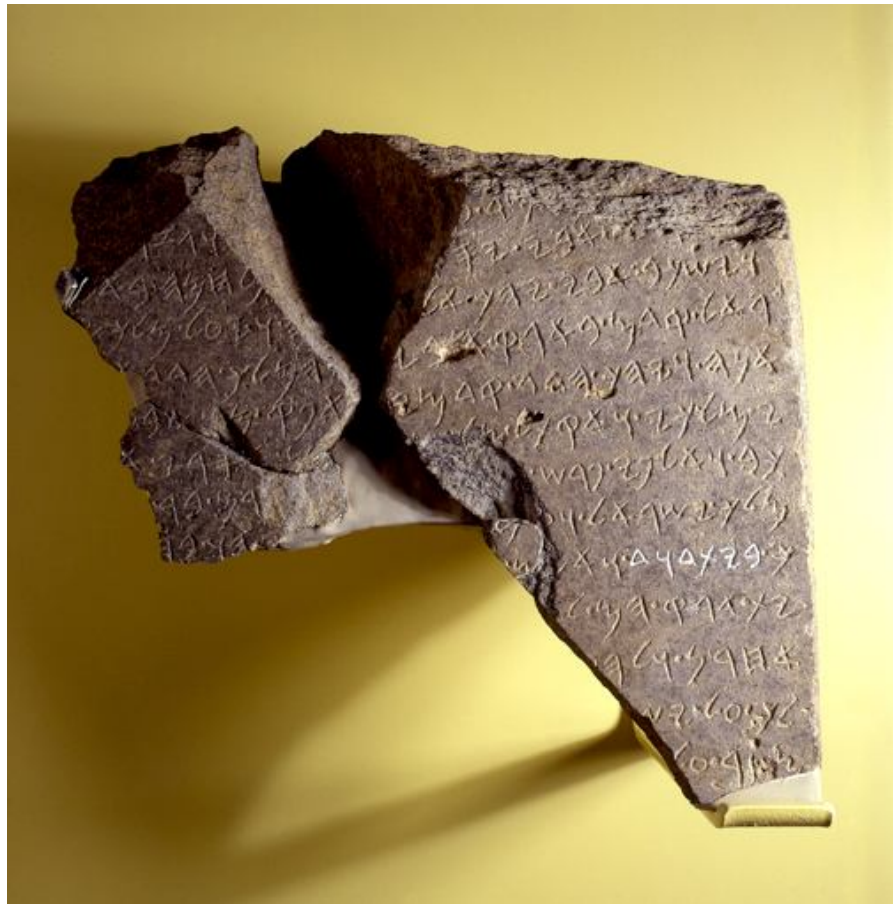

Figura 1

"Casa de Davi”, inscrito numa Estela de Vitória do rei de Aram Hazael, Tel Dan, século 9 a.e.c.

The Israel Museum, Jerusalém

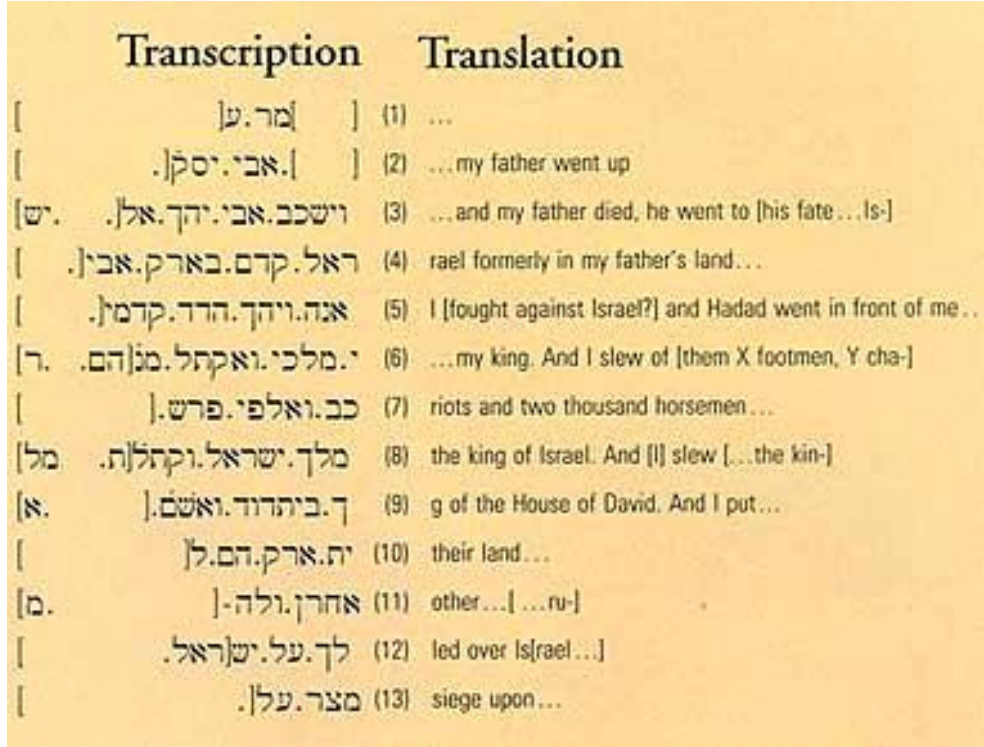

Figura 2

Tradução da Estela de Tel Dan 
Anexo 2

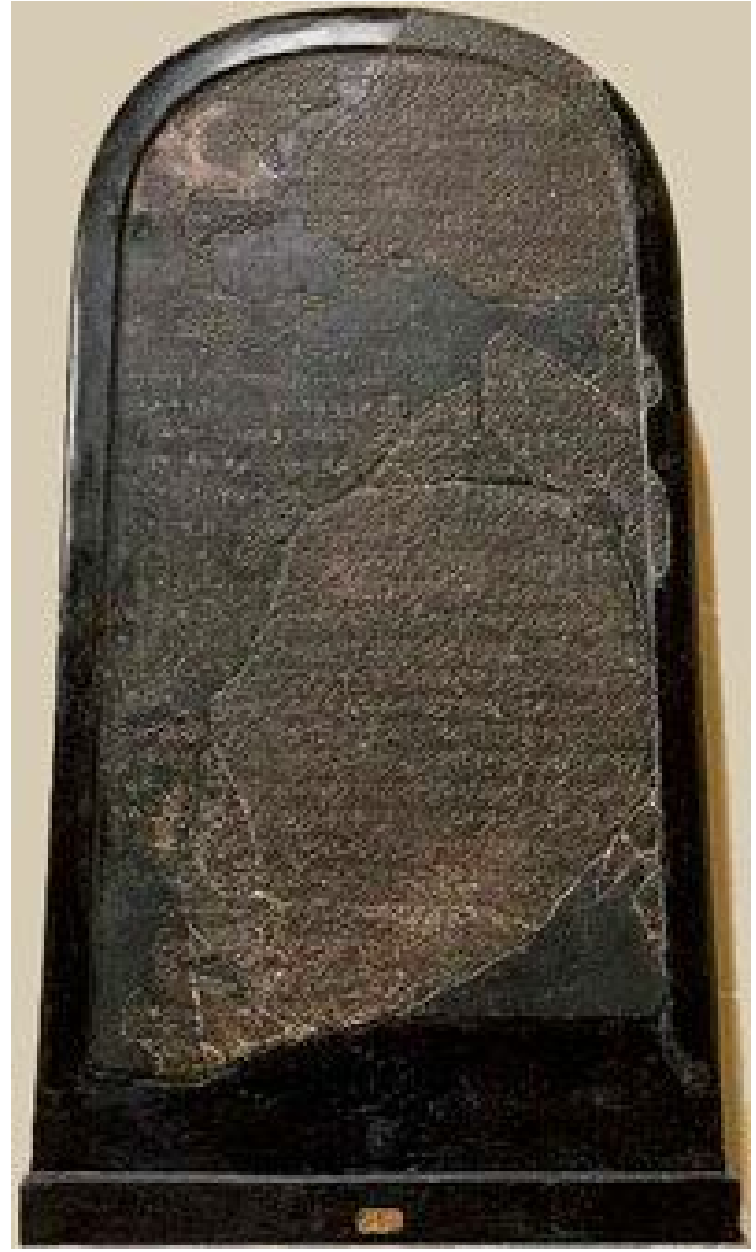

Figura 3

Estela de Mesha

Museu do Louvre, Paris. 


\begin{tabular}{|c|c|c|}
\hline אנוכי מישע בן כמוש[ית] מלך מואב הד- & 1. & אנכ. משע. בני. כמש ... מלכ. מאב. הד \\
\hline יבוני. אבי מלך על מואב שלושים שנה ואנוכי מלכ- & 2. & יבני | אבי. מלכ. על. מאב. שלשנ. שת. ואנכ. מלכ \\
\hline תי אחר אבי. ואעשה הבמה הזאת לכמוש בקרחה, במ[ת י[- & 3. & תי אחר. אבי | ואעש הבמת. זאת. לכמש. בקרחה במ... \\
\hline שע, כי הושיעני מכל המלכים וכי הראני בכל שונאי. עמר- & 4. & שע. כי. השעני. מכל. המלכנ. וכי. הראני. בכל. שנאי | עמר \\
\hline י מלך ישראל עינה את מואב ימים רבים, כי יאנף כמוש באר- & 5. & '. מלכ. ישראל. ויענו. את. מאב. ימנ. רבנ. כי. יאנפ. כמש .באר \\
\hline בימי אמר כ[ר] אותו בנו (של עמרי), ויאמר גם הוא: "אענה את מואב." & 6. & כ... | ויחלפה. בנה. ויאמר. גמ. הא. אענו. את. מאב | בימי. אמר \\
\hline (ל)עולם. ויירש עמריתו (= במפלתו ובמפלת ביתו) וישראל אבוד אבד & 7. & וארא. בה. ובבתה | וישראל. אבד. אבד. עלמ. וירש. עמרי. את \\
\hline ץ מידבא וישב בה (כל) ימיו וחצי ימי בנו - ארבעים שנה. ויש- & 8. & צ. מהדבא | וישב. בה. ימה. וחצי. ימי. בנה. ארבענ. שת .ויש \\
\hline (מפעל אמוש בימי. ואבנה אמים ואבנה בעל-מעון ואעשה בה (את) האשוח & 9. & בה. כמש. בימי | ואבנ. את. בעלמענ. ואעש. בהץ האשוח .ואבנ \\
\hline מלך קרייתיים. ואיש (=שבט) גד יושב בארץ עטרות מעולם. ויבנה לו & 10. & יןת. קריתנ | ואש. גד. ישב. בארצ. עטרת. מעלמ. ויבנ. לה. מלכ . \\
\hline שראל את עטרות. ואלחם בעיר ואכבשנה. ואהרוג את כל העם [מ]- & 11. & העם.... שתל. את. עטרת | ואלתחמ. בקר. ואחזה | ואהרג. את. כל. \\
\hline ואבי- העיר, קרבן (ז) לכמוש ולמואב. ואשבה משם את אריאל דודה (?) & 12. & הקר. רית. לכמש. ולמאב | ואשב. משמ. את. אראל. דודה .ואם \\
\hline או לפני כמוש בקריות. ואושיב בה את איש שרון ואת איש & 13. & חבה. לפמי. כמש. בקרית | ואשב. בה. את. אש. שרנ. ואת .אש \\
\hline מחרת. ויאמר לי כמוש: "לך כבוש את נבו מישראל". וא- & 14. & מחרת | ויאמר. לי. כמש. לכ. אחז. את. נבח. על. ישראל | וא \\
\hline לך בלילה ואלחם בו מבקוע השחר עד הצהריים ואכ- & 15. & הלכ. בללה. ואלתחמ. בה. מבקע. השחרת. עד. הצהרמ | ואח \\
\hline בשעו ואהרוג (את) כולו, שבעת אלפים גברים ונערים (?) ונשים & 16. & זה. ואהרג. כלה. שבעת. אלפנ. גברנ. וגרנ. | וגברת .וגר \\
\hline ופלגשים (?), כי לעשתר-כמוש החרמתים. ואקח משם א[ת כ[- & 17. & ת. ורחמת | כי. לעשתר. כמש. החרמתה | ואקח. משמ. א... \\
\hline לי ה' ואביאם לפני כמוש. ומלך ישראל בנה את & 18. & לי. יהוה. ואסחב. המ. לפני, כמש | ומלכ. ישראל. בנה .את \\
\hline יהץ וישב בה בהילחמו בי. ויגרשו כמוש מפני, ו- & 19. & יהצ. וישב. בה. בהלתחמה. בי | ויגרשה. כמש. מפני | \\
\hline אקח ממואב מאתיים איש, כל אנשי (?), ואעלה אותם על יהץ & 20. & אקח. ממאב. מאתנ. אש. כל רשה | ואשאה. ביהצ. ואחזה. \\
\hline לספחה לדיבון. אנוכי בניתי (את) קרחה, (את) חומות היערים & 21. & לספת. על. דיבנ |אנכ. בנתי. קרחה. חמת. היערנ. וחמת \\
\hline העופר. ואנוכי בניתי שעריה ואנוכי בניתי מגדליה וא- & 22. & העפל | ואנכ. בנתי. שעריה. ואנכ. בנתי. מגדלתה | וא \\
\hline המים) למים בקרבי בית-מלך ואנוכי עשיתי כלאי האשוח (= מפעל אספקת & 23. & נכ. בנת', בת. מלכ. ואנכ. עשתי. כלאי. האשו ... ינ .בקרב \\
\hline העיר. ובור אין בקרב העיר, בקרחה. ואומר לכל העם: "עשו ל- & 24. & הקר | ובר. אנ. בקרב. הקר. בקרחה. ואמר. לכל. העמ. עשו .ל \\
\hline אם איר- בור בביתו". ואנוכי כריתי שוחות (?) לקרחה ב(עזרת) & 25. & כמ. אש. בר. בביתה | ואנכ. כרתי. המכרתת. לקרחה. באסר \\
\hline י ישראל. אנוכי בניתי (את) ערוער ואנוכי עשיתי מסילות בארנון. & 26. & '. ישראל | אנכ. בנתי. ערער. ואנכ. עשת'. המסלת .בארנג. \\
\hline (היתה (עיים. בית-במות כי הרוס הוא. אנוכי בניתי (את) במר כע & 27. & אנכ. בנתי. בת. במת. כי. הרס. הא | אנכ. בנתי. בצר .כי. עינ \\
\hline ] ...אי]ש דיבון חמישים, כי כל דיבון (0רה ל) משמעתי. ואנוכי מלכ- & 28. & ....ש. דיבנ. חמשנ. כי. כל. דיבנ. משמעת | ואנכ. מלכ \\
\hline תי (על) המאות בערים אשר סיפחתי על ארצי. ואנוכי בנית- & 29. & ת.... מאת. בקרנ. אשר. יספתי. על. הארצ | ואנכ. בנת \\
\hline ]' את מי] דבא ובית דבלתיים ובית בעל-מעון ואביא לשם את [נוק- & 30. & ........ \\
\hline די לרעות את] צאן הארץ. וחורונים יושבים בה... & 31. & ........... הארצ | וחורנג. ישב. בה. ב.... \\
\hline ] ] [..... & 32. & .......... \\
\hline חם בעיר ואכבשה. וישב] בה כמוש בימי ...... משם עש..... & 33. & ........... כמש. בימי. ועל... משמ.... \\
\hline (......... שדק. וא & 34. & |................ \\
\hline
\end{tabular}

Figura 4

O texto da Estela de Mesha com tradução para o hebraico.

SASS, Benjamin. Script and Inscriptions in the Biblical Period (em hebraico).

Open University, Tel Aviv, 1992, pp.30-34. 
Anexo 3
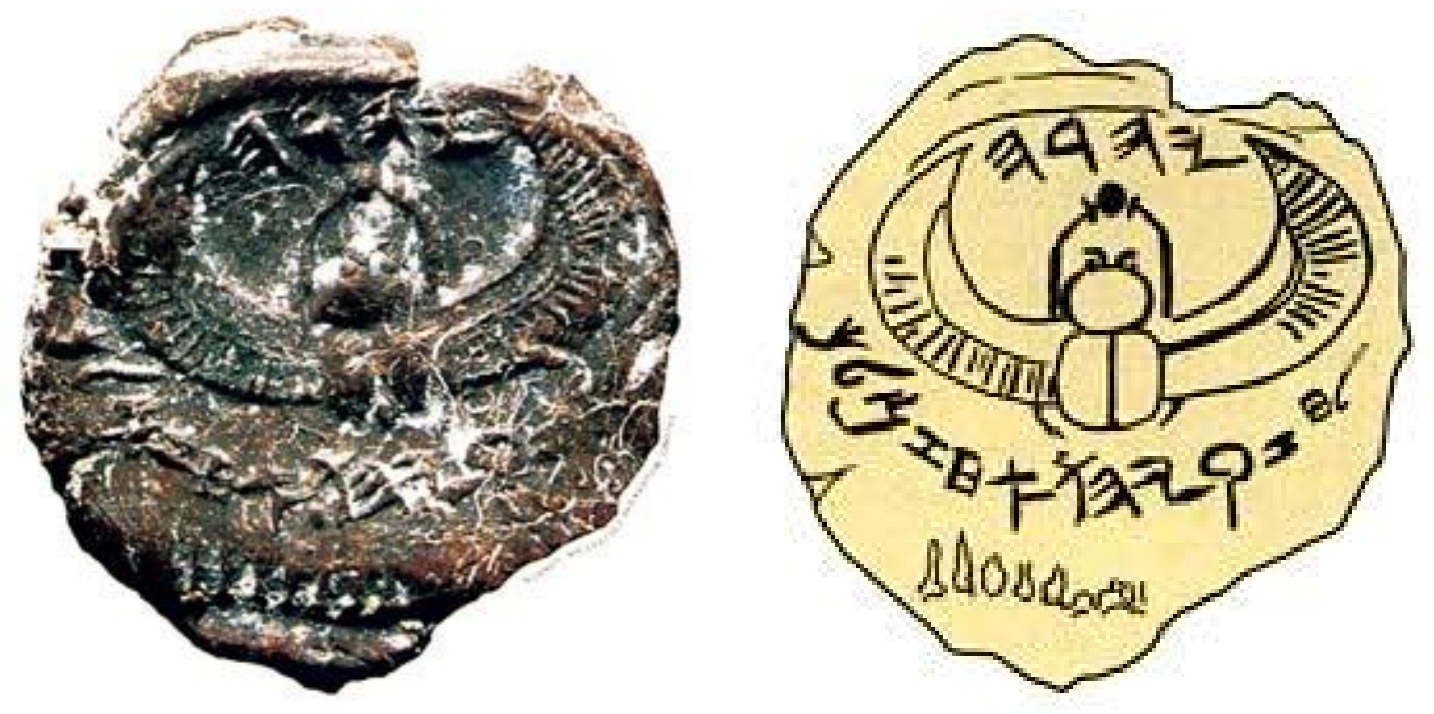

Figura 5

O Bullae de Ezequias

Shlomo Moussaieff Collection, Londres 
Anexo 4

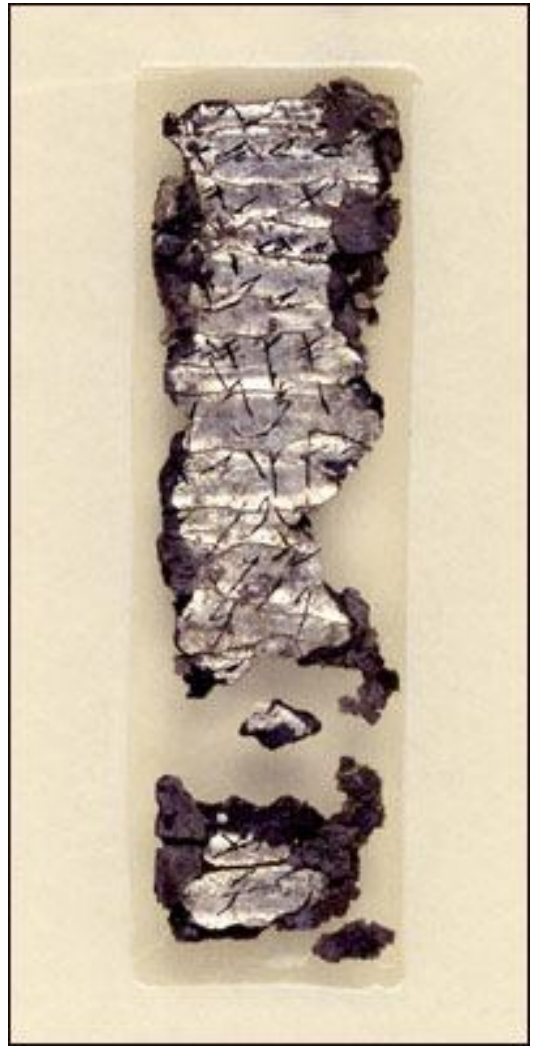

Figura 6

A Benção dos Sacerdotes

The Israel Museum Jerusalém 


\section{Anexo 5}

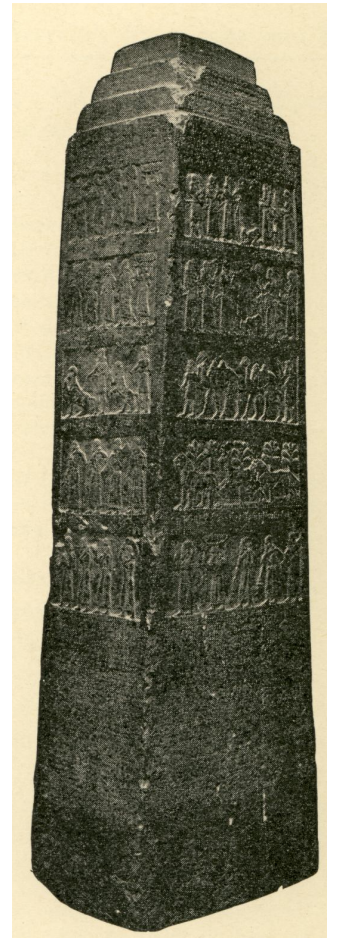

Figura 7

Obelisco Negro de 825 a.e.c.

Reinado de Shalmaneser III

British Museum, Londres

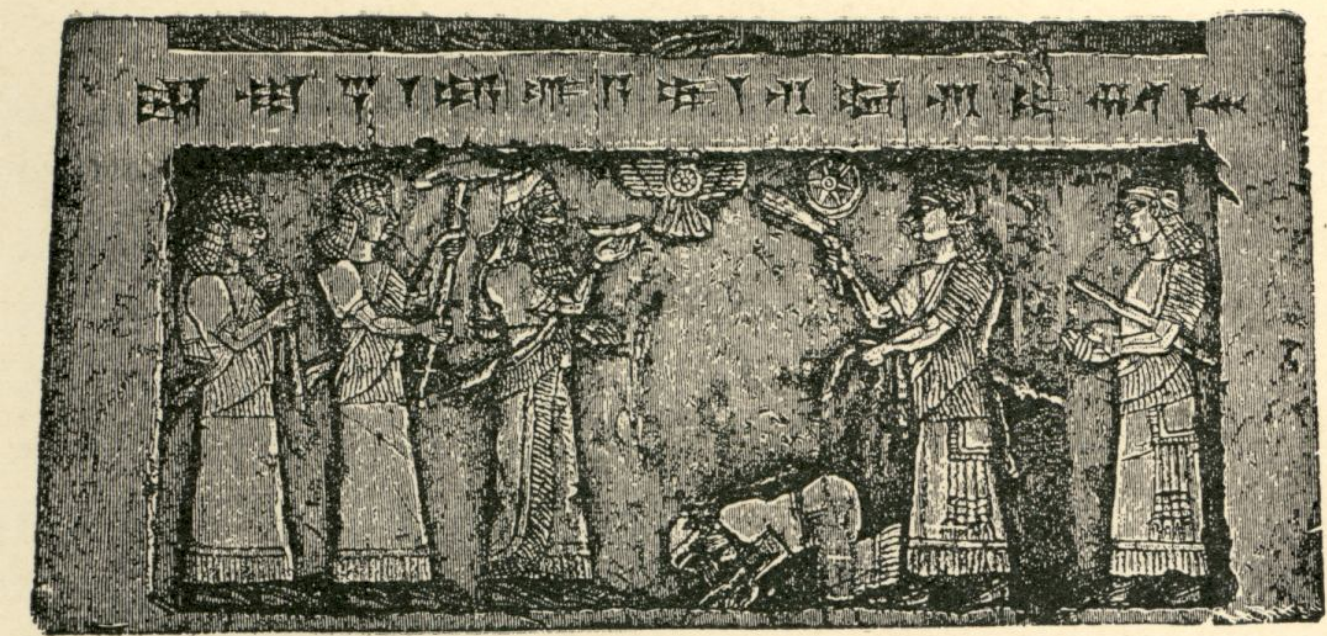

Figura 8

Detalhe do Obelisco Negro:

Jehu, rei de Israel se ajoelha perante o rei assírio Shalmaneser III

British Museum, Londres 


\section{Anexo 6}

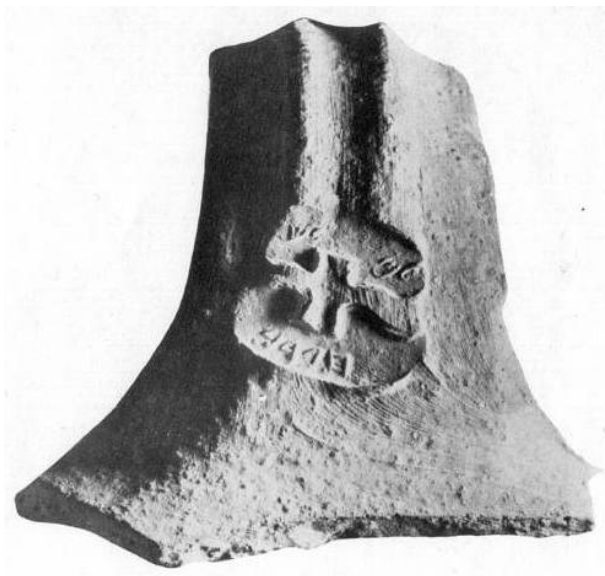

Figura 9

Alça de vaso "lmlk" com a inscrição: למלכ חברנ

(Pertencente ao Rei de Hebron)

Com besouro de duas asas, 2,2x2,2cm

Museu Rockfeller Jerusalém

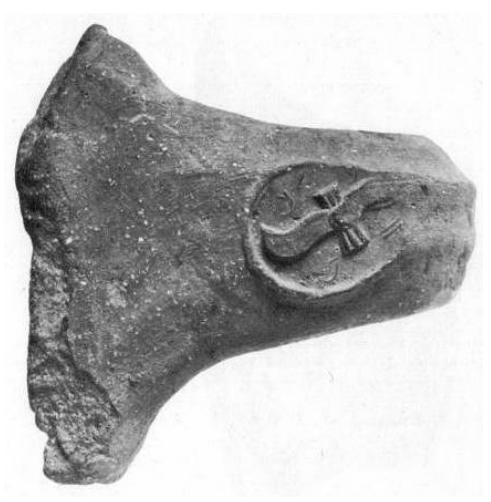

Figura 11

Alça de vaso "lmlk" com a inscrição:

למלכ זפ

(Pertencente ao rei de Zif)

Com besouro de duas asas, $2 \times 3 \mathrm{~cm}$

Museu de Israel, Jerusalém

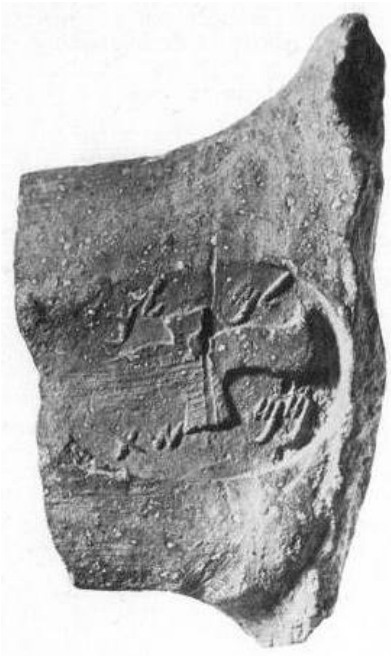

Figura 10

Alça de vaso "lmlk" com a inscrição: למלכ ממשת

(Pertencente ao rei de Mmst)

Com besouro de duas asas, $2 \times 3 \mathrm{~cm}$

Museu de Israel, Jerusalém

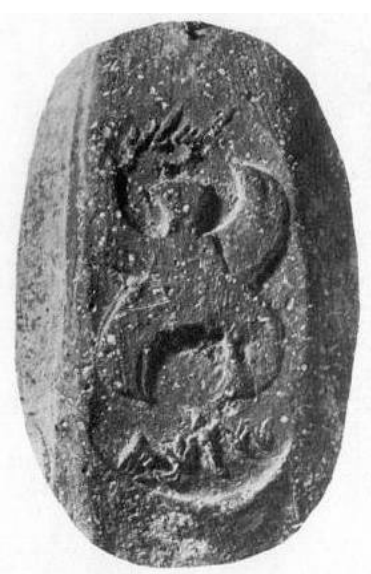

Figura 12

Selo "Imlk" com a inscrição: למלכ שוכה

(Pertencente ao rei de Soco) Com besouro de quatro asas, $3,7 \times 1,8 \mathrm{~cm}$ Museu Rockfeller, Jerusalém 


\section{Anexo 7}
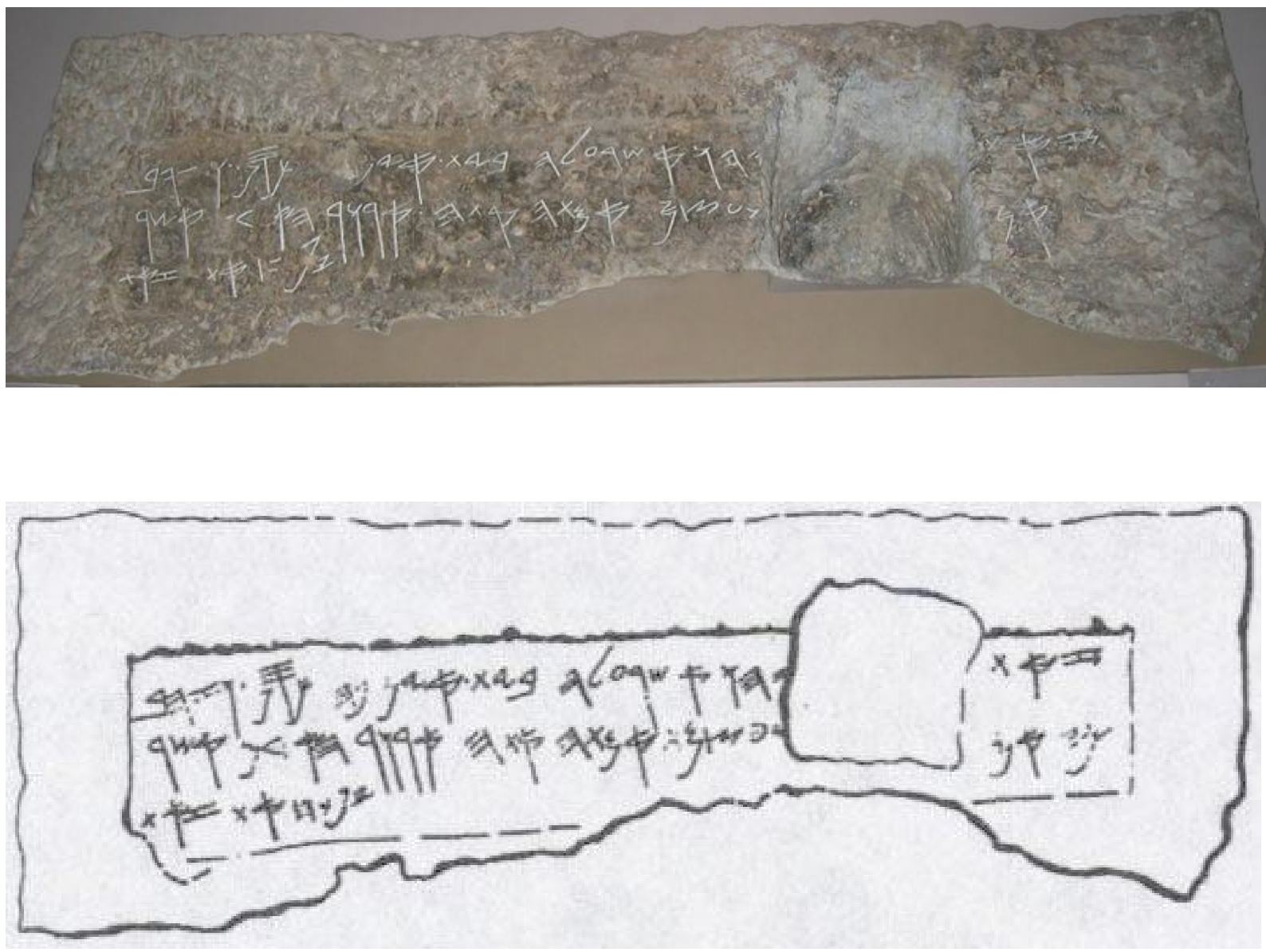

Figura 13

"Asher al Habait" British Museum, Londres

"[the tomb of ...] yahu, who is over the house. There is no silver and gold here but rather [his bones] and the bones of his wife (?) with him. Cursed be the man who should open this".

Tradução de: Ussishkin David, A recently Discovered Monolithic Tomb in Siloam. In: Jerusalem Revealed, Archaeology in the Holy City 1968-1974, The Israel Exploration Society, Jerusalem, 1975 p. 64

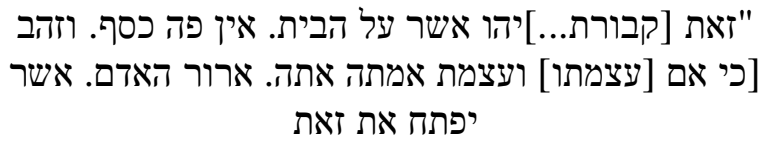




\section{Anexo 8}

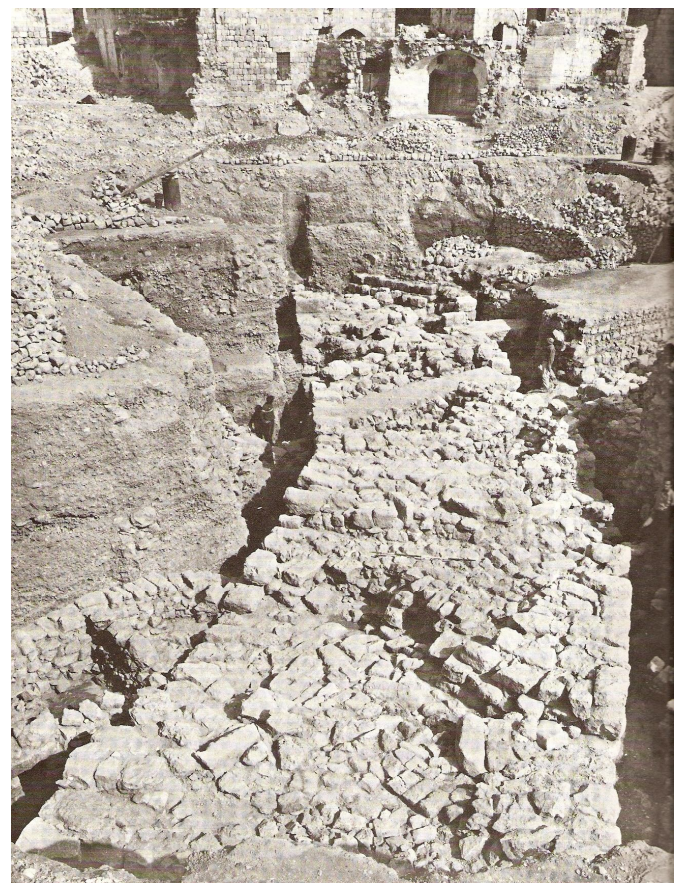

Figura 14

"A Larga Muralha” Bairro Judeu da cidade Velha de Jerusalém

Avigad Nahman, Excavations in the Jewish Quarter of the Old City, 1969-1971.

In: Jerusalem Revealed - Archaeology in the Holy City 1968-1974,

The Israel Exploration Society, Jerusalém, 1975 p. 42

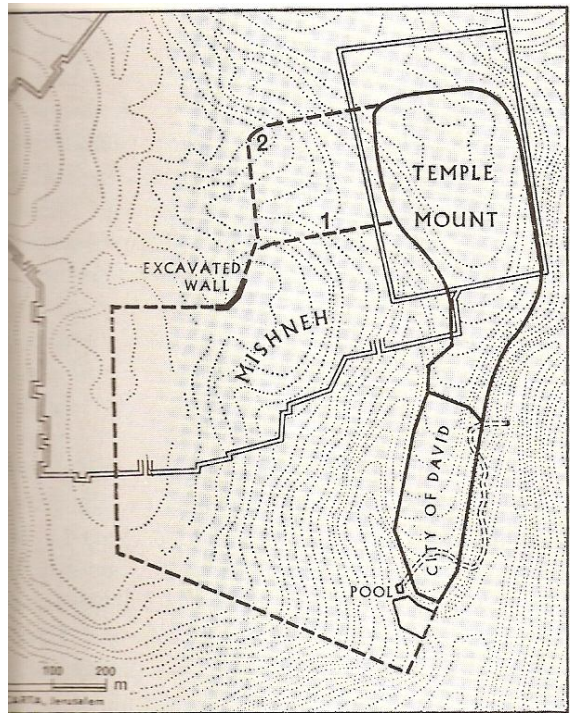

Figura 15

Mapa topográfico de Jerusalém, mostrando as linhas de fortificação no Bairro Judeu e os contornos da muralha da cidade durante os séculos 8 e 7 a.e.c.

Avigad Nahman, Excavations in the Jewish Quarter of the Old City, 1969-1971. In: Jerusalem Revealed - Archaeology in the Holy City 1968-1974, The Israel Exploration Society, Jerusalém, 1975 p. 43 


\section{Anexo 9}

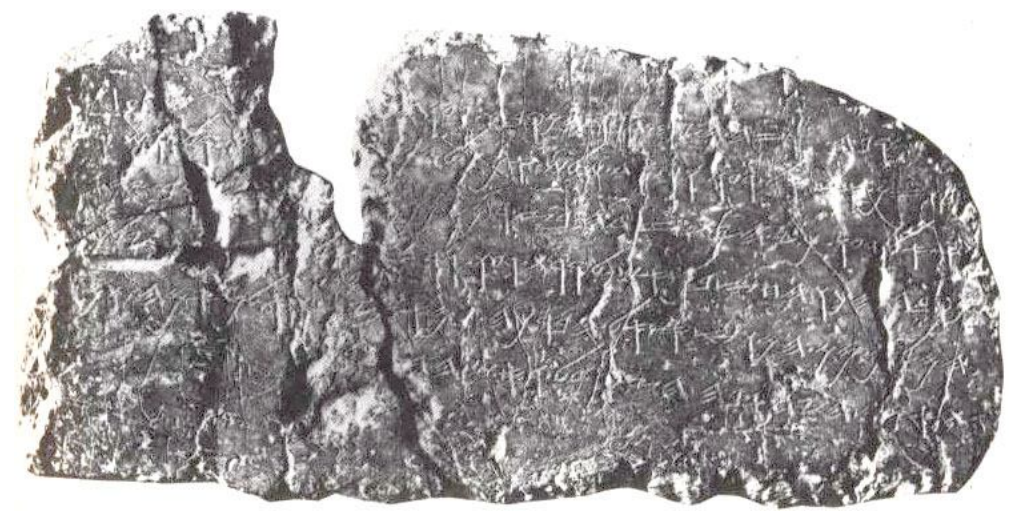

Figura 16

A Inscrição de Siloé

Istambul Museum

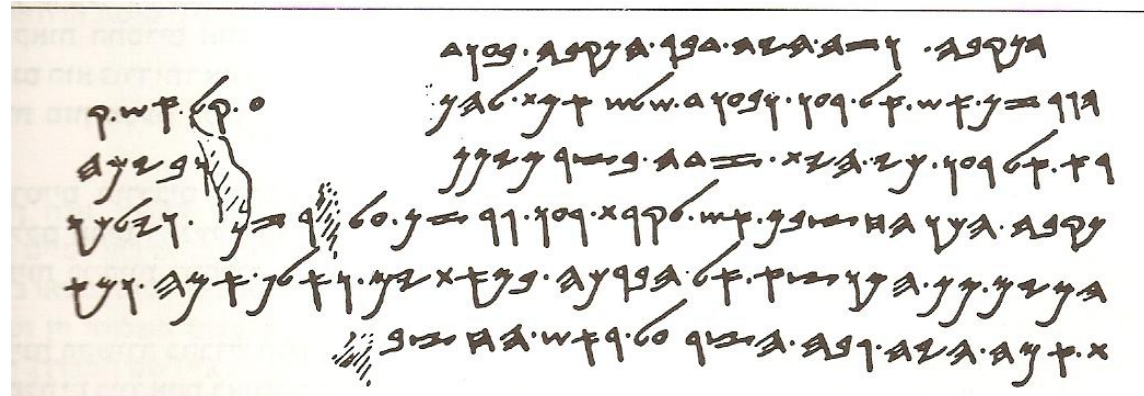

1. [דבר.] הנקבה. וזה. היה. דבר. הנקבה. בעוד [.מנפם. החצבים. את.]

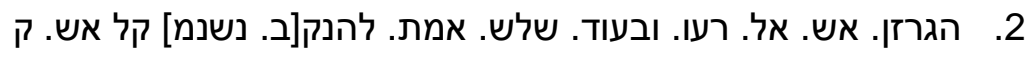

3.

4.

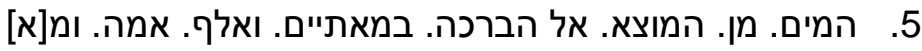

6. ת. אמה. היה. גבה. הצר. על. ראש. החצבים.

“... The tunnelling (was finished). And this was the matter of the tunnelling: While [the hewers yielded] the axe, each man toward his fellow, and while there were still three cubits to be he[wn, there was hear]d a man's voice call/ing to his fellow, for there was a crack (?) in the rock on the righy and [on the lef]t. And at the end of the/tunnelling the hewers hacked each man towards his fellow, axe upon axe. And there flowed / the waters from the spring towards the reservoir for two hundre[d and] a / thousand cubits. And a hu[nd]red cubits was the height of the rock above the head(s) of the hewers"

Tradução: Amiran, Ruth. The Water Supply of Israelite Jerusalem, in: Jerusalem Revealed - Archaeology in the Holy City 1968-1974,

The Israel Exploration Society, Jerusalém, 1975, p. 78. 


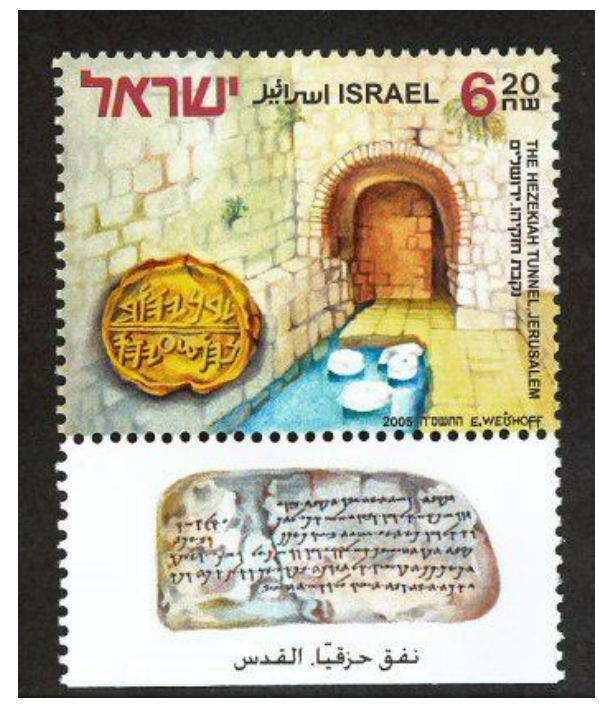

Figura 17

"Túnel de Ezequias, Jerusalém"

Selo da série "Projetos de água em Israel na antiguidade"

Data de emissão: 22/02/2005

Desenhado por: Eliezer Weishof

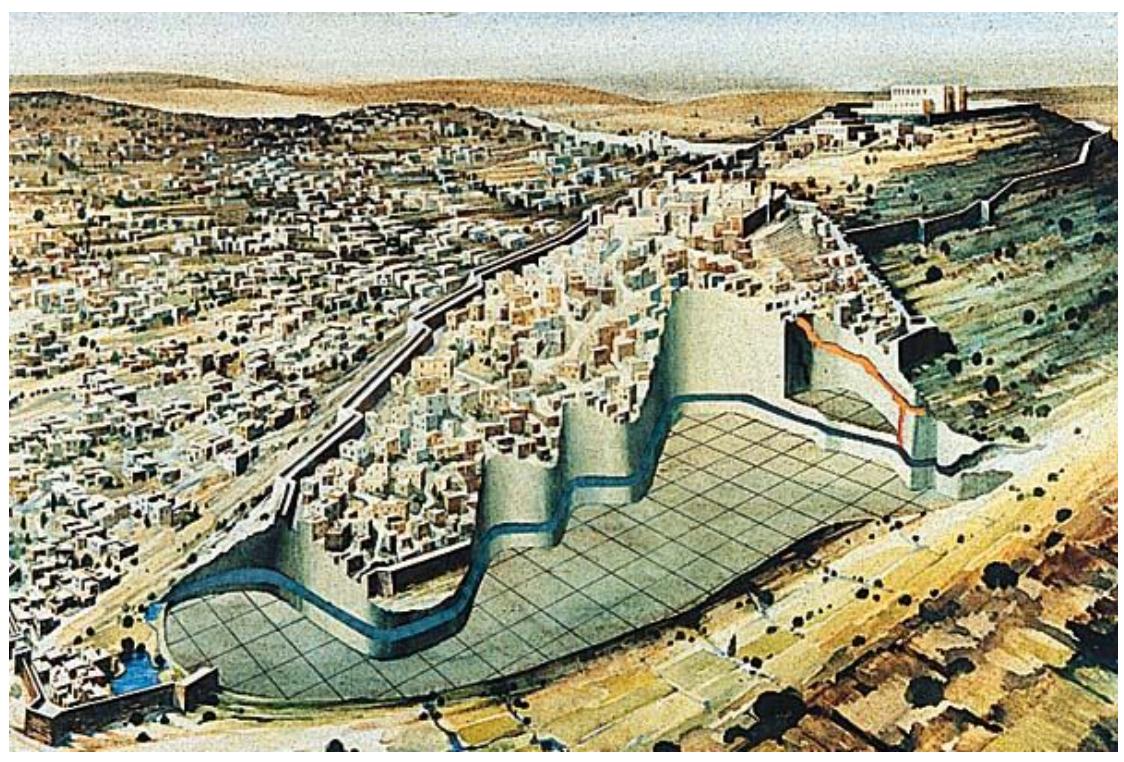

Figura 18

Modelo do túnel de Ezequias

Migdal Davi Museum, Jerusalém 


\section{Anexo 10}

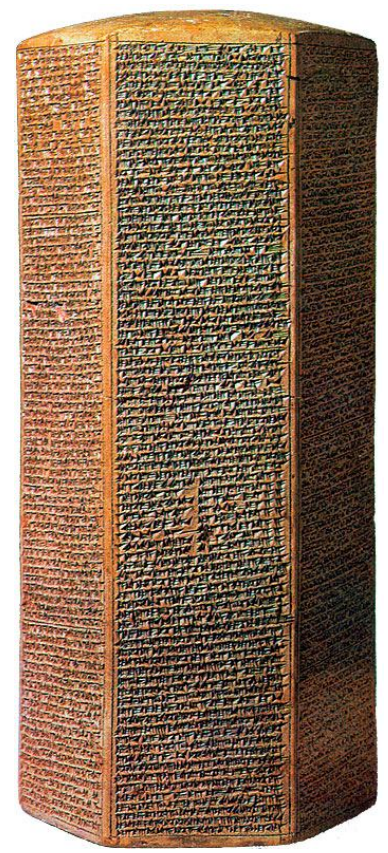

Figura 19

Taylor Prism, 700 a.e.c.

British Museum, Londres

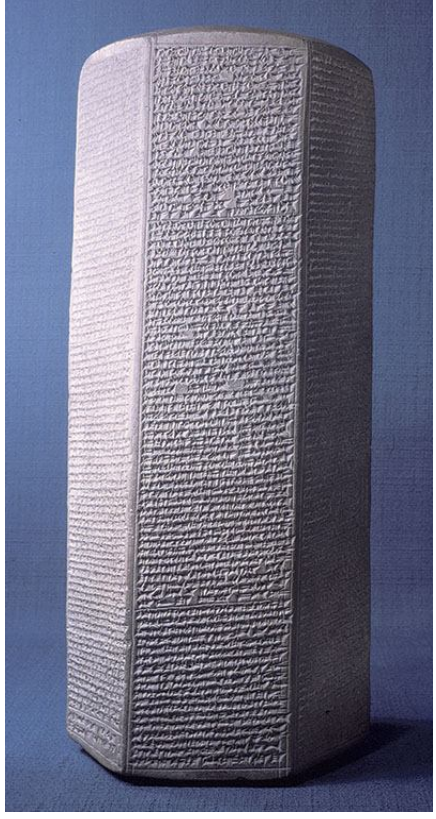

Figura 20

Sennacherib Prism 689 a.e.c.

Oriental Institute, Chicago

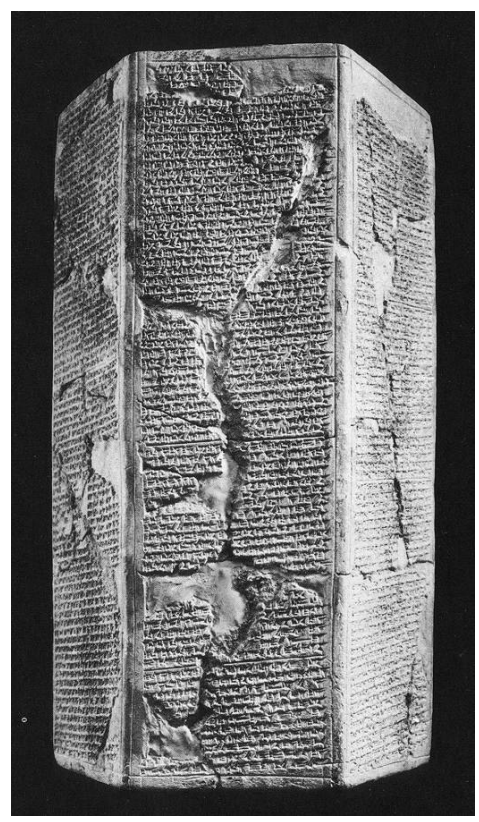

Figura 21

Sennacherib Prism, 691 a.e.c Israel Museum, Jerusalém 


\section{Anexo 11}

Todos os desenhos dos relevos de Laquish, a seguir, foram feitos por Judith Dekel, e estão publicados no livro de Ussishkin, David. The Conquest of Lachish by Sennacherib, Instituto de Arqueologia, Tel Aviv, 1982.

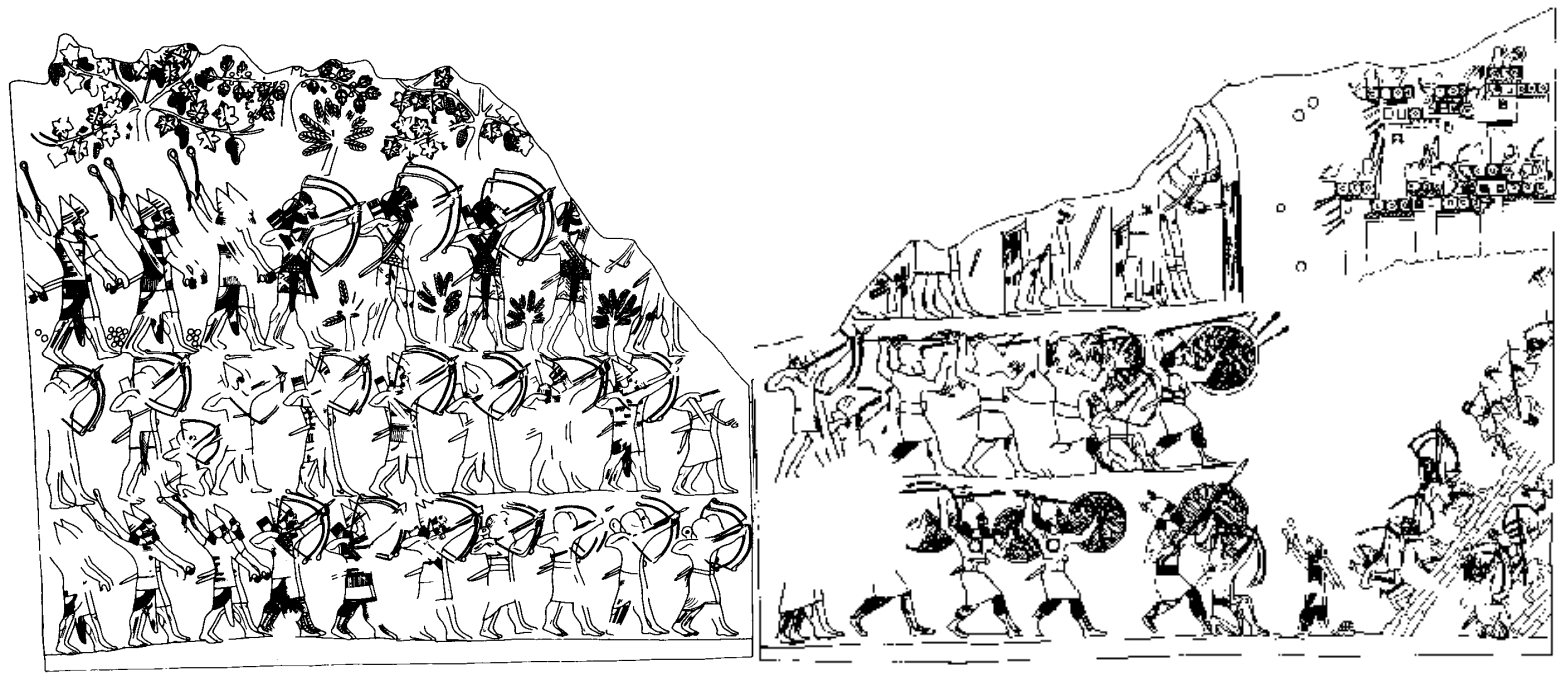

Figura 22

As medidas do painel $2,31 \times 1,82$

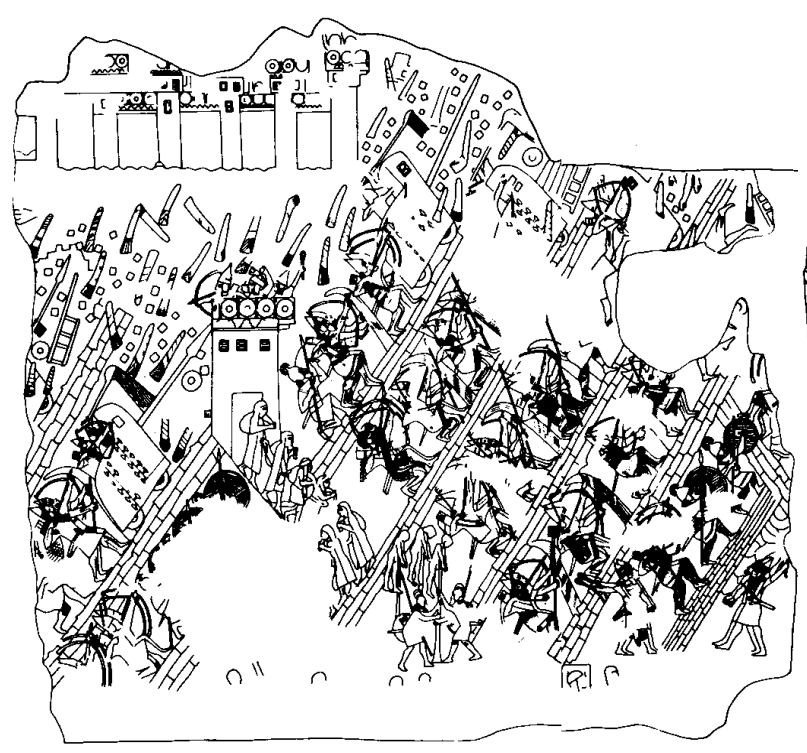

Figura 24

As medidas do painel 1,88X1,64
Figura 23

As medidas do painel 2,24x1,72

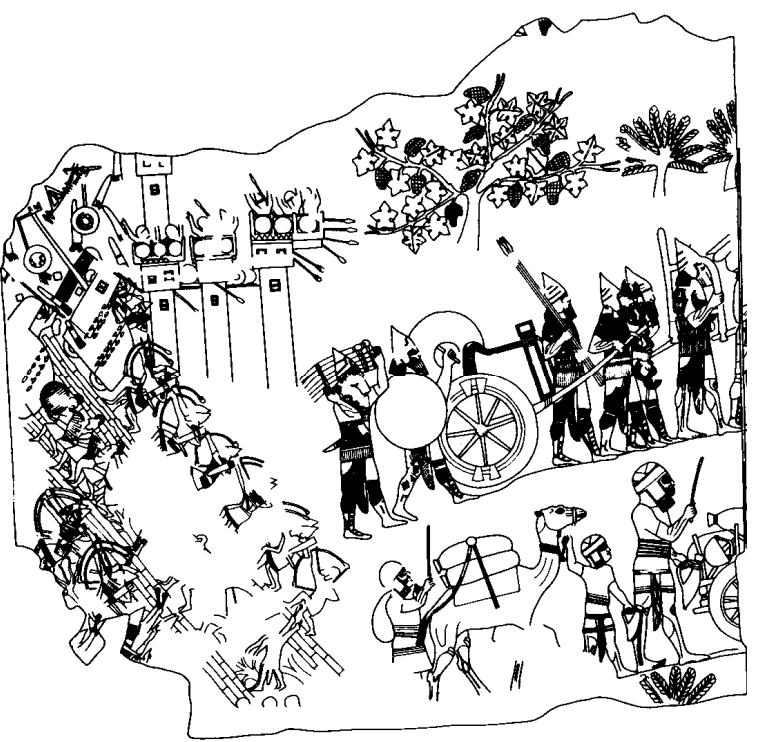

Figura 25

As medidas do painel 1,91X1,70 


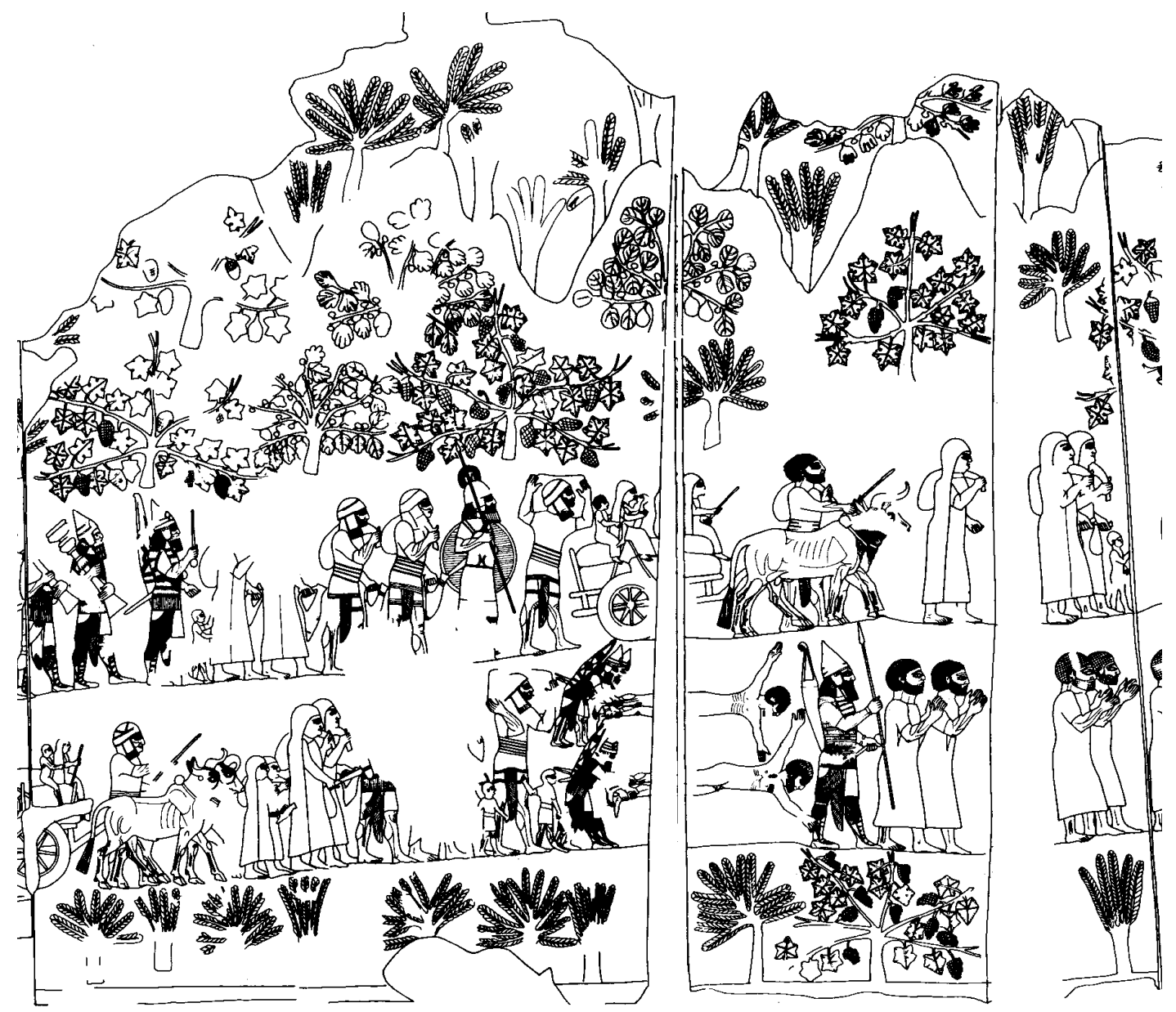

Figura 26

Figura 27

As medidas do painel 1,80X2,96

As medidas do painel 1,12X2,52 


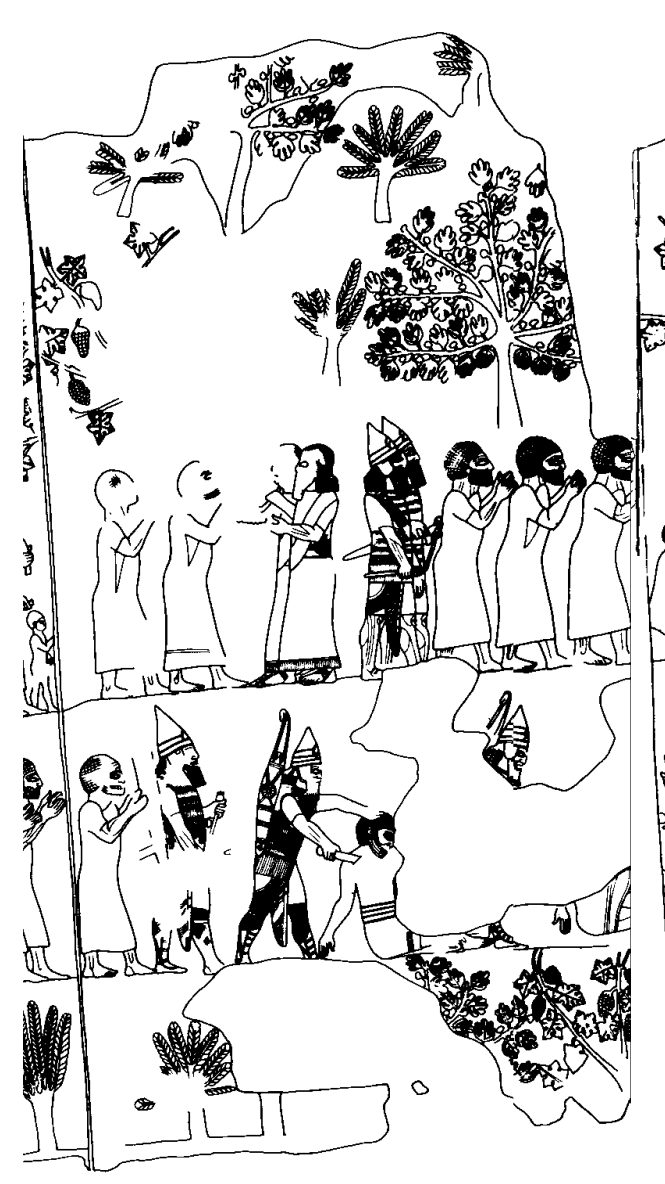

Figura 28

As medidas do painel 1,32X2,48

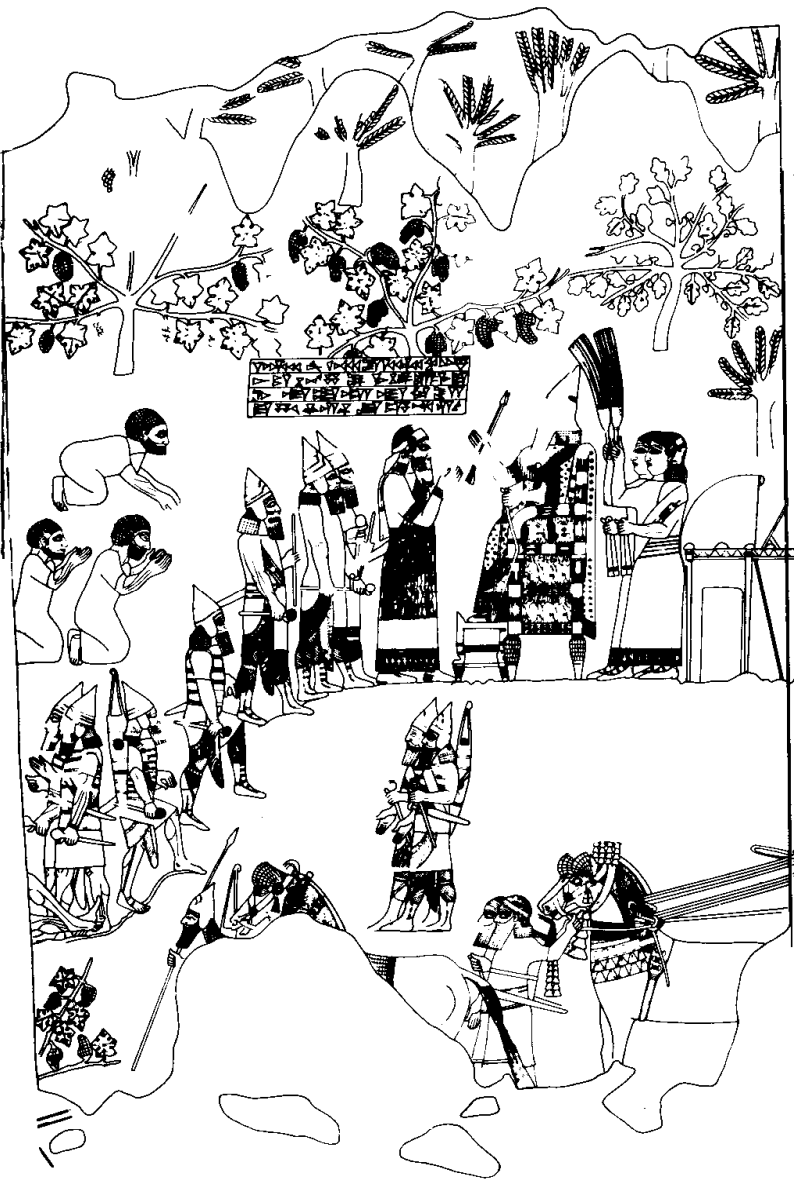

Figura 29

As medidas do painel 1,75X2,49 


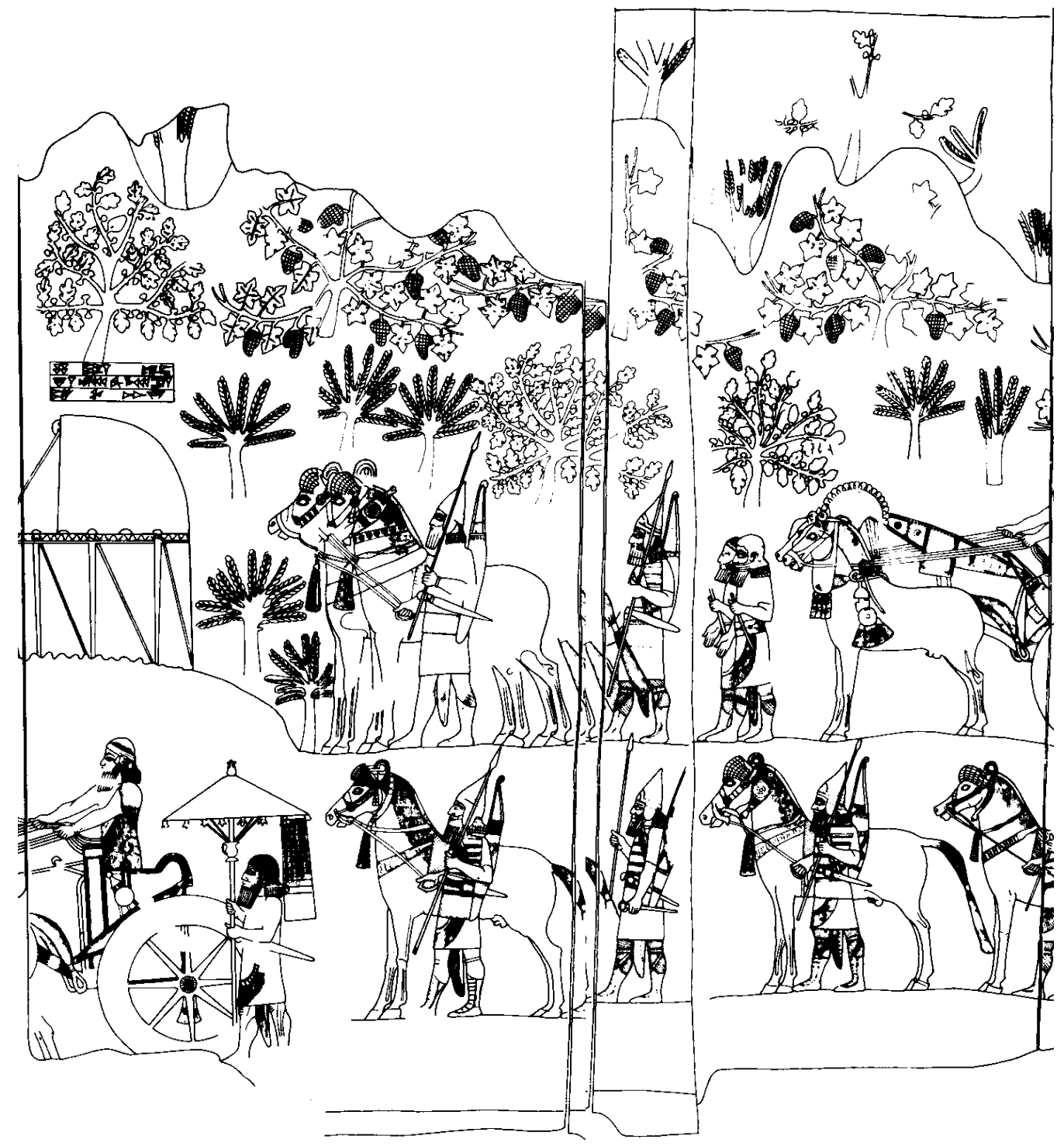

Figura 30

As medidas do painel $1,31 \mathrm{X} 2,34$
Figura 31

As medidas do painel $1,20 \mathrm{X} 2,74$ 


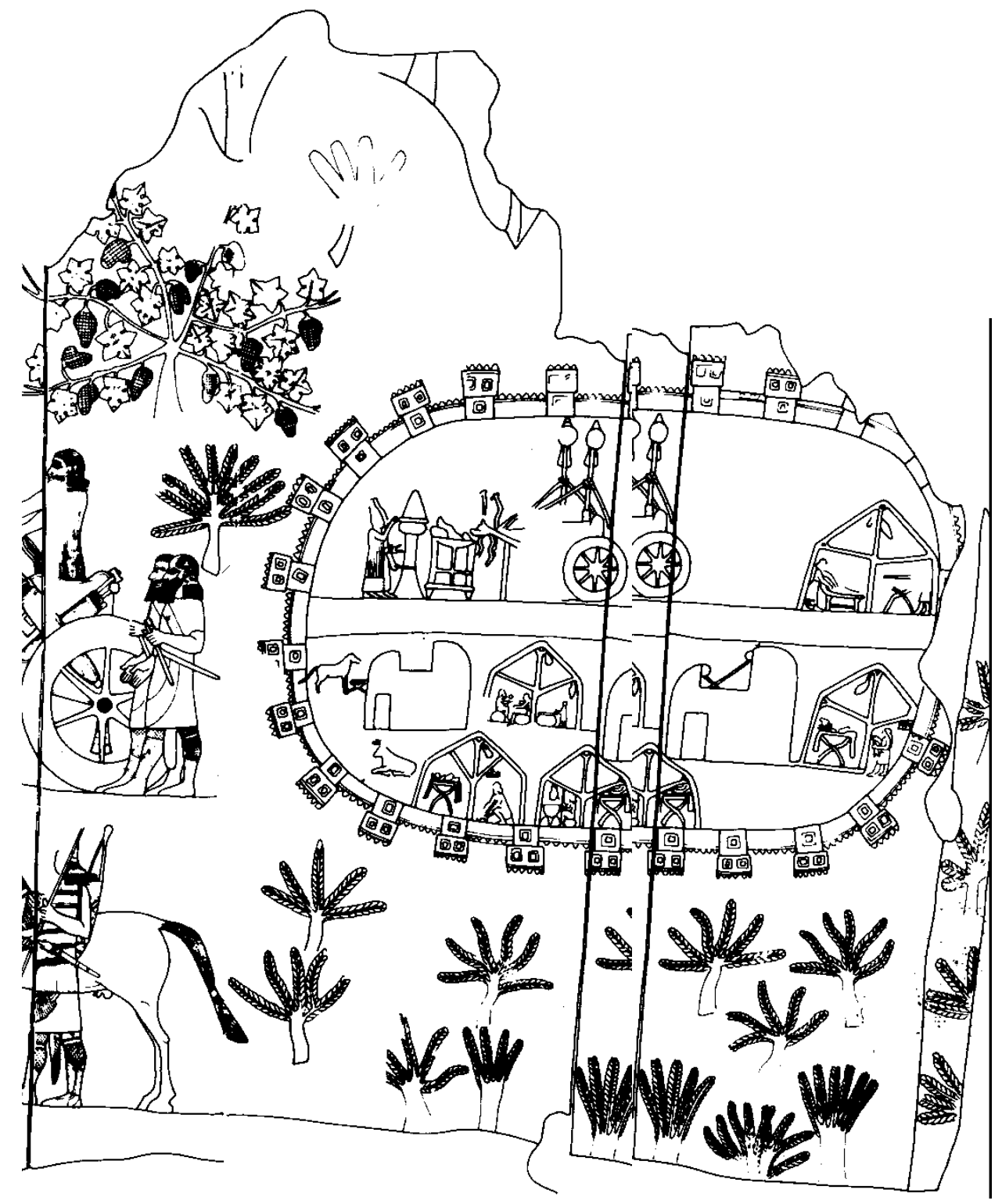

Figura 32

Figura 33

As medidas do painel 1,16X2,31 As medidas do painel 0,69X1,70 


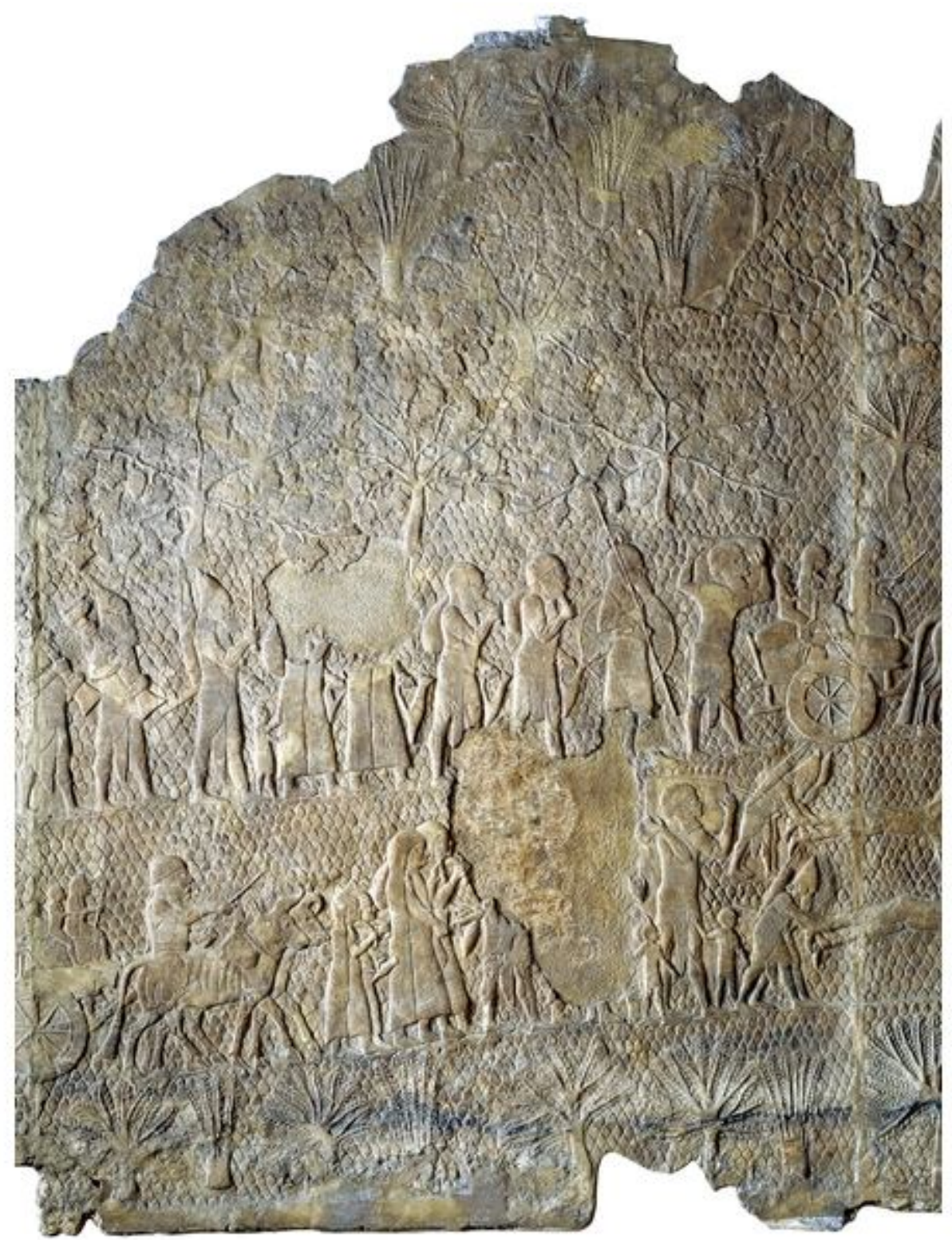

Figura 34

Painel dos relevos de Laquish

British Museum, Londres 


\section{Anexo 12}

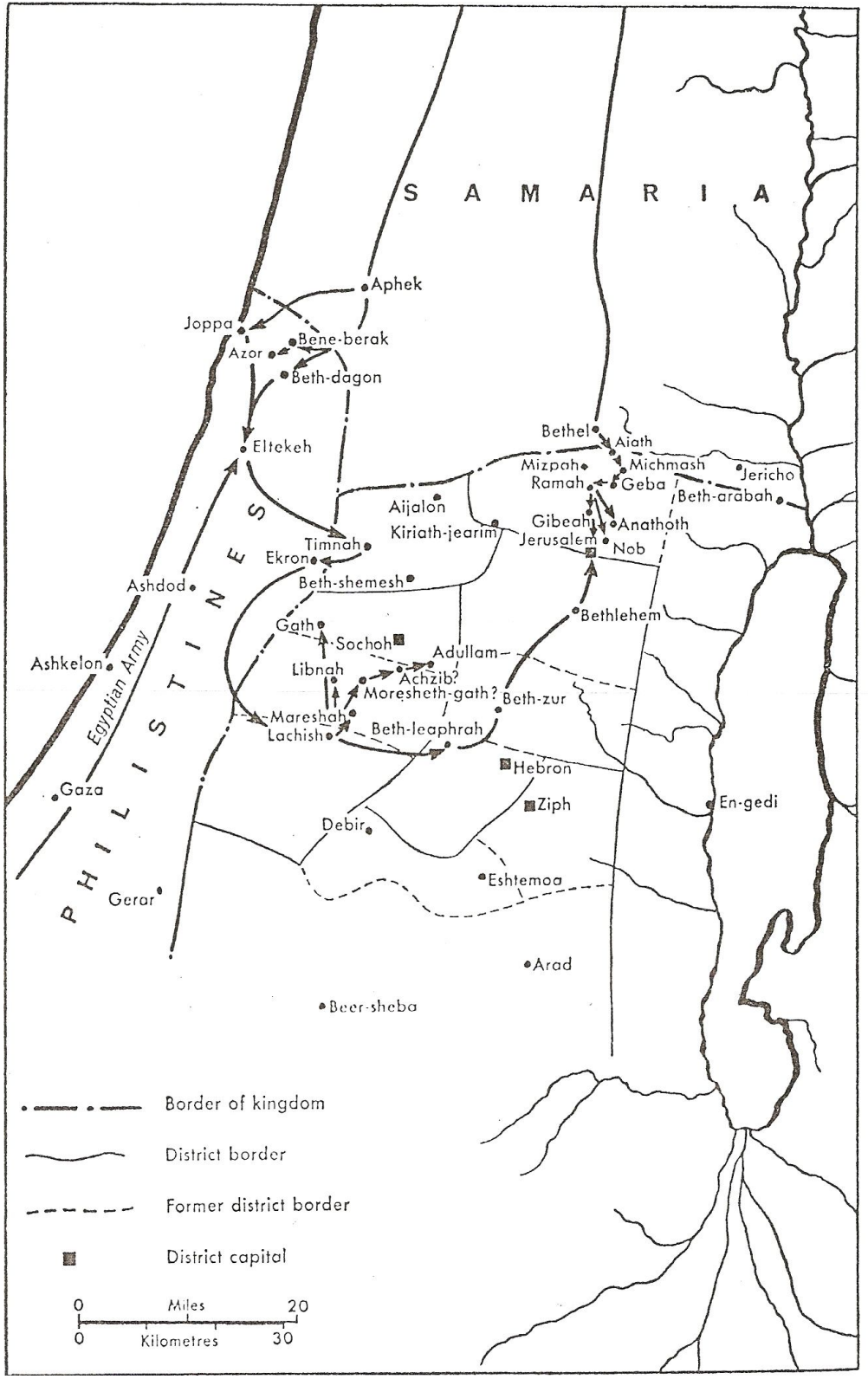

Figura 36

Os municípios de Judá na época de Ezequias e

A Jornada de Senaquerib

Aharoni Yohanan, The Land of the Bible, A Historical Geography, Borns \& Oates, London 1968, p.338 